LILIANE DOS SANTOS MACHADO

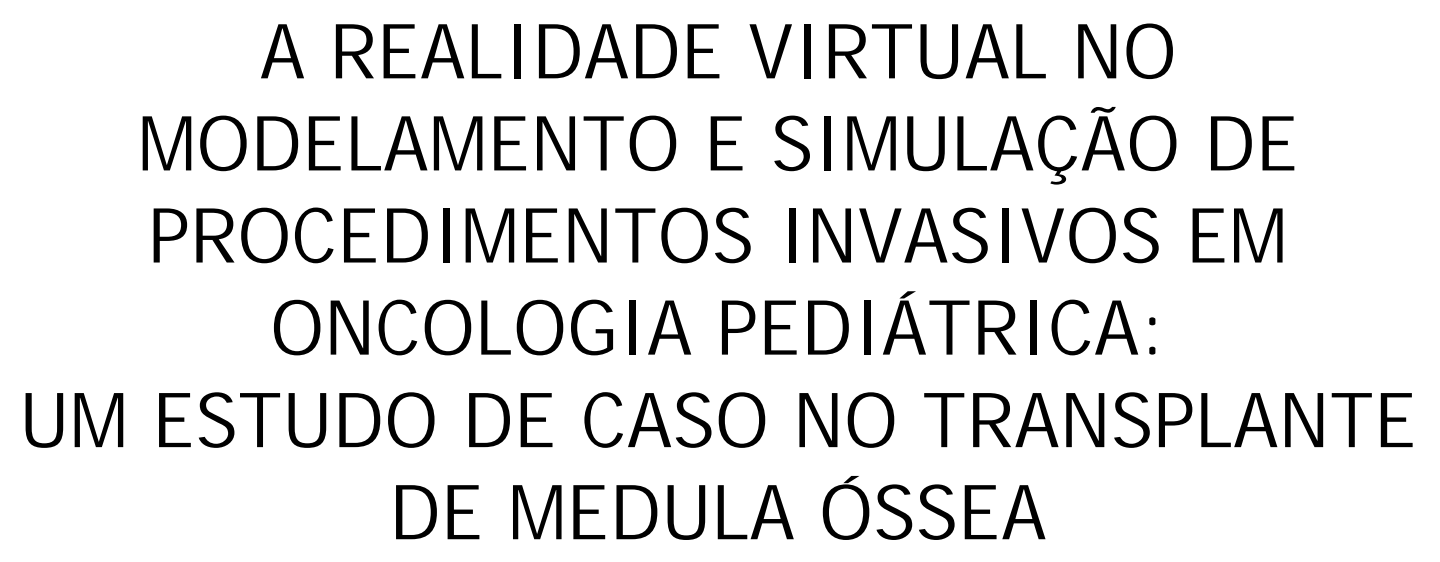

SÃO PAULO

2003 


\section{A REALIDADE VIRTUAL NO MODELAMENTO E SIMULAÇÃO DE PROCEDIMENTOS INVASIVOS EM ONCOLOGIA PEDIÁTRICA: UM ESTUDO DE CASO NO TRANSPLANTE DE MEDULA ÓSSEA}

Tese de Doutorado apresentada à Escola Politécnica da Universidade de São Paulo para obtenção do título de Doutora em Engenharia.

Área de Concentração:

Sistemas Eletrônicos

Orientador:

Prof. Dr.

Marcelo Knörich Zuffo 
Este exemplar foi revisado e alterado em relação à versão original, sob responsabilidade única do autor e com a anuência de seu orientador.

São Paulo, 25 de março de 2003

Autor:

Orientador:

Machado, Liliane dos Santos

A Realidade Virtual no Modelamento e Simulação de Procedimentos Invasivos em Oncologia Pediátrica: Um Estudo de Caso no Transplante de Medula Óssea, 2003, 116 p. Edição Revisada.

Tese (Doutoramento) - Escola Politécnica da Universidade de São Paulo. Departamento de Engenharia de Sistemas Eletrônicos.

1. Realidade Virtual, 2. Oncologia Pediátrica, 3. Simulação, 4. Transplante de Medula Óssea.

Universidade de São Paulo. Escola Politécnica da Universidade de São Paulo. Departamento de Engenharia de Sistemas Eletrônicos. 


\section{Dedicatória}

Folheando teses e dissertações na biblioteca encontrei em uma delas a frase: "Só sabe quem fez!". Perfeita. Mas acredito que o meu fazer só foi possível porque existem pessoas especiais em minha vida, que através de seu carinho e apoio vibraram e sofreram comigo durante todo o processo. A vocês, queridos Ronei, papai, mamãe e Luci dedico este trabalho. 


\section{Agradecimentos}

Qual é o sentido da vida? Por que faço isso? Qual o verdadeiro valor do trabalho científico? 0 que me motiva? Onde vou chegar?

Por muitas vezes me deparei com esses dentre outros questionamentos (e não foram poucas as vezes) e recolhi-me em pensamentos sobre o que estava de fato fazendo e objetivando. Por longas noites de difícil sono e dias curtos de intenso trabalho o tempo foi passando. Posso dizer que não obtive todas as respostas que procuro e que muitas a vida me reserva para descobertas futuras, provavelmente para que toda a emoção não se perca de uma só vez... Das respostas que alcancei a que guardo com mais convicção é que nada, simplesmente nada, teria valor se não houvesse 0 encontro: 0 encontro de pessoas e suas idéias, de pessoas e suas formas de expressão. Nada teria sentido se no caminho não estivessem a família, os professores, os amigos e os colegas. Existe uma grande Razão que permitiu nos encontrarmos. A todos vocês que tanto me ensinaram, ajudaram e apoiaram em cada momento fica o meu sincero agradecimento.

Em particular, agradeço à minha irmã Luciane, meu marido Ronei, meu pai José, minha mãe Lucinda, ao Celso, Adilson, Alice, Anelise, Fabio, Laura, Lídio, Luciano, Márcio, Marco Antonio, Paulo, Régis, Ricardo, Rodrigo, Ruslaine e professora Roseli; aos médicos do Departamento de Pediatria do Hospital das Clínicas, doutores Vicente Odone Filho e Andre Nebel de Mello; e ao meu orientador Marcelo Knörich Zuffo.

Agradeço também à FAPESP (processo 99/01583-0) e à FINEP-RECOPE (projeto "Visualização na Engenharia") pelo apoio financeiro a este trabalho, e à USP e ao LSI pela oportunidade. 


\section{Resumo}

Este trabalho aborda o uso da realidade virtual aplicada à simulação de procedimentos invasivos em oncologia pediátrica. Para tanto, apresenta uma revisão dos conceitos relacionados à concepção de simuladores baseados em realidade virtual, descrevendo requisitos específicos como estereoscopia e interação háptica. Particularmente, é apresentado um estudo de caso em coleta de medula óssea para transplante, para o qual um simulador foi desenvolvido.

Este é o primeiro trabalho em simulação cirúrgica para oncologia pediátrica baseado em realidade virtual e apresenta detalhes relacionados à implementação do simulador e aspectos relacionados à calibragem de propriedades físicas em modelos tridimensionais. 0 trabalho também analisa e demonstra vantagens no uso de sistemas dessa natureza voltados para o treinamento médico, apontando necessidades e novos problemas a serem tratados por simuladores futuros. 


\section{Abstract}

This work approaches the use of the Virtual Reality applied to the simulation of invasive procedures in pediatric oncology. It presents a revision of the concepts related to the conception of simulators based on virtual reality, describing requirements as stereoscopy and haptic interaction. As specific problem, it was made a case study in bone marrow harvest for transplant, for which a simulator was developed.

This is the first work in surgical simulation for pediatrics based on Virtual Reality and it presents details related to the implementation of the simulator and aspects related to physical properties in three-dimensional models. The work also analyzes and demonstrates advantages in the use of this kind of system for medical training besides to point needs and new problems to be addressed in future work. 


\section{Sumário}

\section{Resumo}

Abstract

\section{Sumário}

\section{Lista de Tabelas}

\section{Lista de Figuras}

\section{Lista de Abreviaturas}

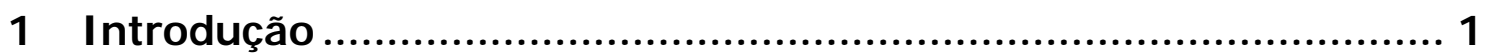

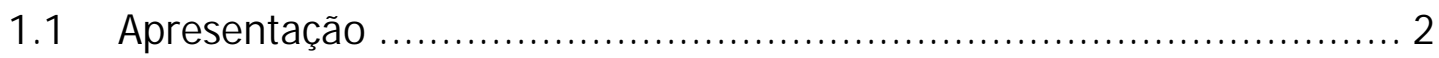

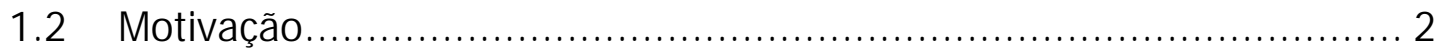

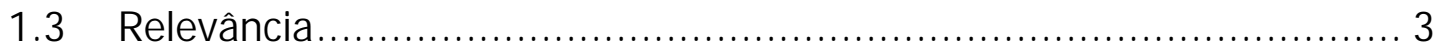

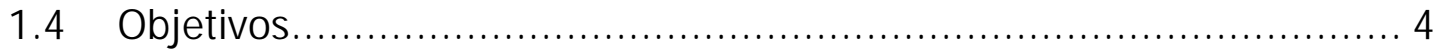

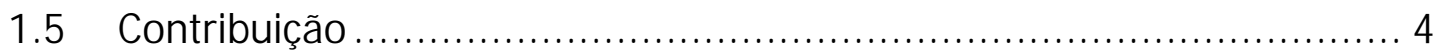

1.6 Trabalhos Correlatos na Instituição ……….................................. 5

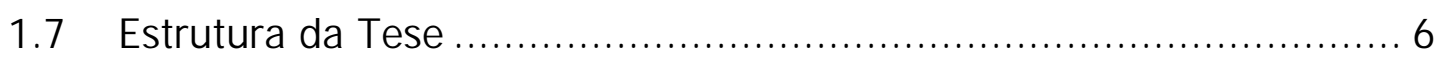

2 Estado da Arte em Realidade Virtual aplicada à Simulação de Procedimentos Médicos I nvasivos ................................................ 8

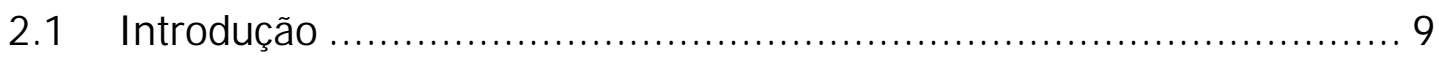

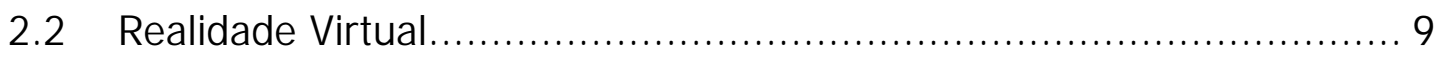

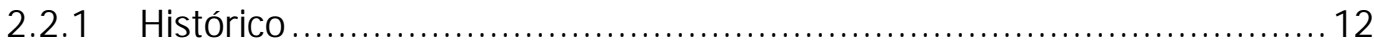

2.3 Exibição de Imagens Estereoscópicas.......................................... 14

2.3.1 Métodos para a Geração de Pares Estereoscópicos............................ 16

2.4 Dispositivos e Sistemas Hápticos............................................... 19

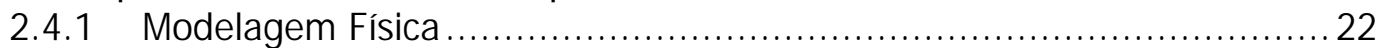

2.4.2 Sistemas Hápticos Baseados em Braços Articulados............................ 24

2.5 Modelos Deformáveis e Tecidos Moles ........................................... 25

2.6 Simulação de Procedimentos Invasivos ........................................... 26

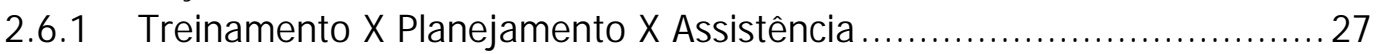

2.7 Simuladores para Medicina .............................................................. 29

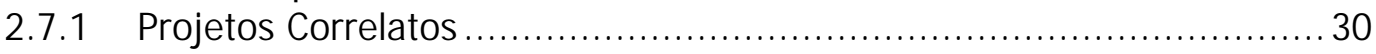

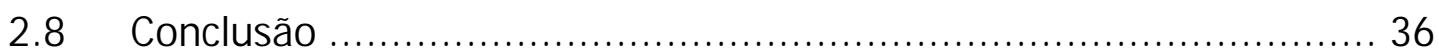




\section{Análise e Requisitos para a Simulação de Procedimentos Invasivos em Oncologia Pediátrica}

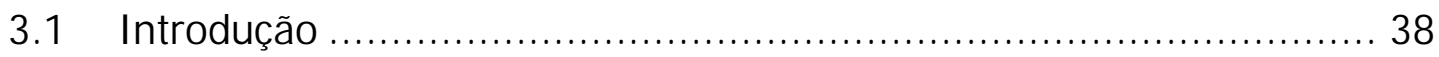

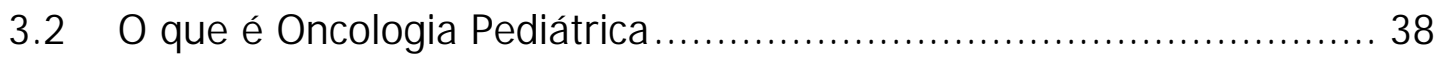

3.3 Procedimentos Invasivos em Oncologia Pediátrica .......................... 39

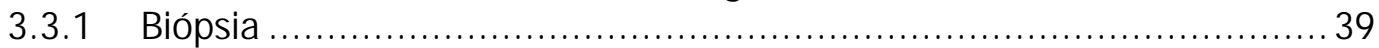

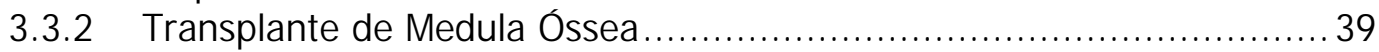

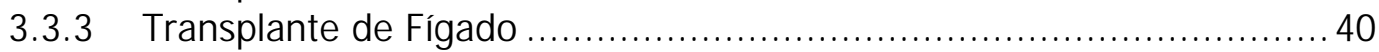

3.3.4 Práticas Correntes de Treinamento …........................................ 41

3.4 Requisitos Para um Sistema de Treinamento ................................ 41

3.5 Proposta de um Sistema de Simulação ......................................... 42

3.5.1 O Transplante de Medula Óssea ................................................... 43

3.5.2 Problema Abordado: A Coleta de Medula Óssea ................................. 46

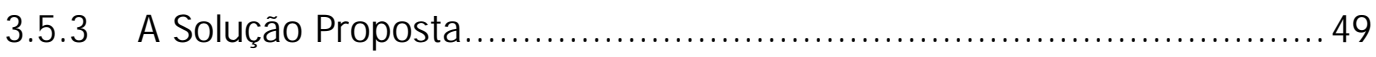

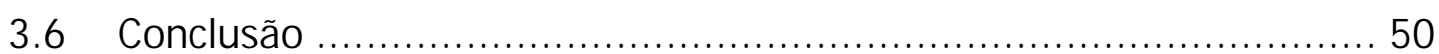

\section{Projeto e I mplementação de um Simulador para}

Treinamento em Coleta de Medula Óssea .................................... 51

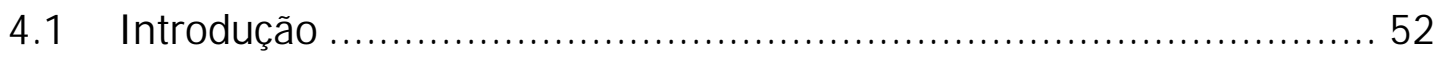

4.2 Descrição Funcional do Simulador ................................................ 52

4.2.1 Módulo de Observação da Anatomia .......................................... 54

4.2.1.1 Submódulo para Observação Interna ……………........................... 54

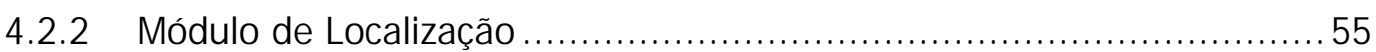

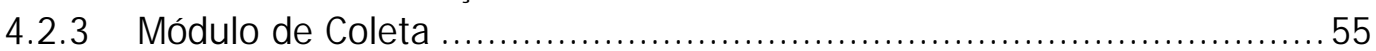

4.3 Definição dos Componentes do Simulador ..................................... 56

4.3.1 Plataforma de Execução............................................................. 57

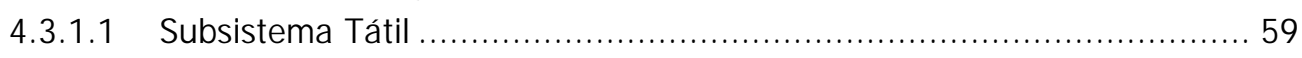

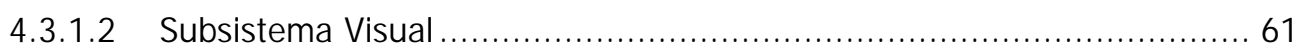

4.3.2 Ambiente de Execução e Programação .............................................. 62

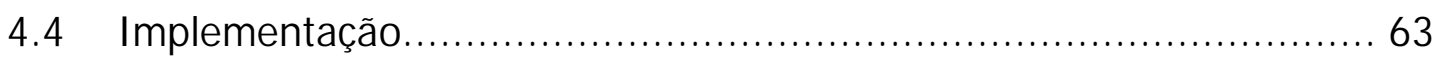

4.4.1 Geração dos Modelos Visuais e Táteis ............................................... 65

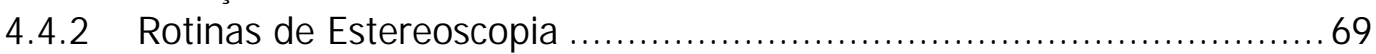

4.4.3 Rotinas de Atuação Háptica.......................................................... 70

4.4.3.1 Programação das Propriedades Físicas Iniciais ................................... 73

4.4.4 Sincronização das Rotinas de Visualização e Háptica........................... 74

4.4.5 Apresentação do Simulador Integrado ......................................... 75

4.5 Calibragem das Propriedades Físicas ........................................ 78

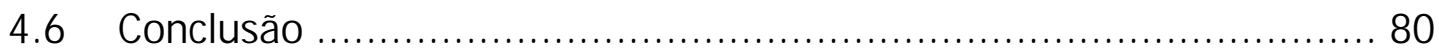


5 Análise e Avaliação dos Resultados............................................ 81

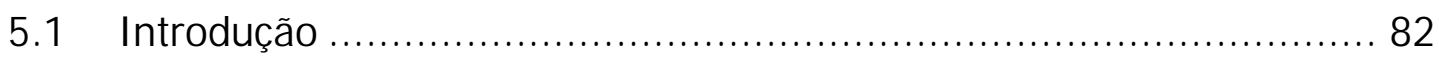

5.2 Análise Comparativa dos Métodos de Treinamento Tradicional e Proposto ........................................................................ 82

5.3 Análise Comparativa do Simulador de Coleta de Medula Óssea com outros Simuladores ................................................................. 84

5.4 Avaliação do Simulador de Coleta de Medula Óssea ......................... 86

5.4.1 Teste do Simulador ............................................................... 86

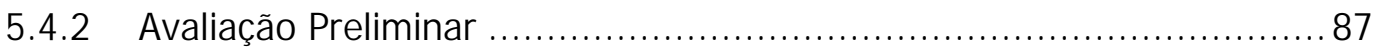

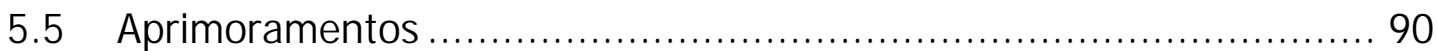

5.5.1 Mesa de Visualização ......................................................... 90

5.5.2 Módulo de Avaliação ............................................................... 92

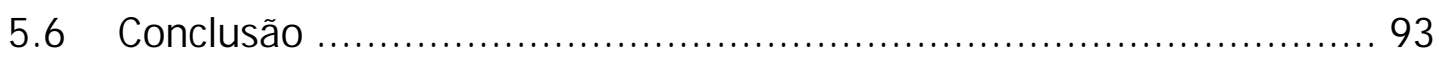

6 Conclusão e Trabalhos Futuros..................................................... 94

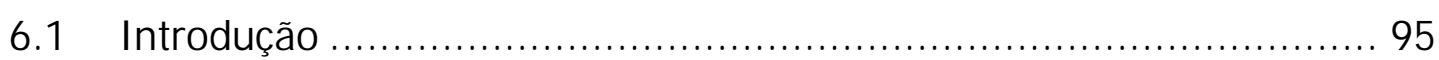

6.2 Considerações sobre a Pesquisa Desenvolvida ............................... 95

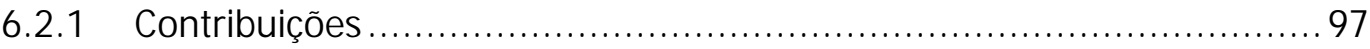

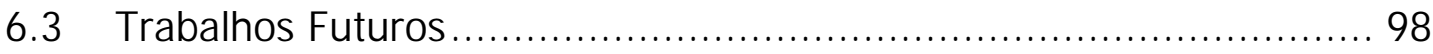

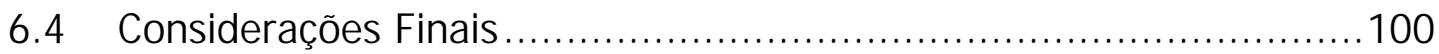

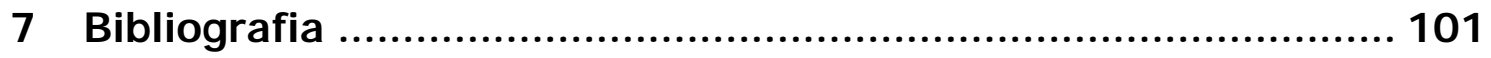

7.1 Bibliografia Complementar........................................................111

8 Anexo 1 - Tabela de Valores de Calibragem ........................... 112

9 Anexo 2 - Diagramas de Classe............................................... 113

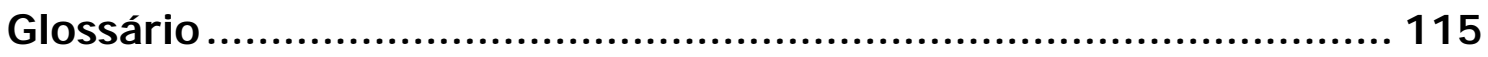




\section{Lista de Tabelas}

Tabela 1: Especificações técnicas do Phantom Desktop. ............................................. 60

Tabela 2: Questionário de avaliação do sistema e as respostas obtidas........................ 88

Tabela 3: Valores utilizados na calibragem das camadas de tecido do Simulador de Coleta de Medula Óssea. 


\section{Lista de Figuras}

Figura 1 : Visão externa e interna do simulador de vôo do Boeing 777. Na visão recortada observa-se o sistema de exibição (1) sobre a cabine e o espelho esférico (2) que a envolve refletindo a imagem exibida para o piloto [Vince, 1995 p.340].....

Figura 2: Os quatro tipos de paralaxe: (a) zero, (b) divergente, (c) positiva e (d) negativa.

Figura 3: As projeções off-axis e on-axis, onde E e D representam os olhos esquerdo e direito, respectivamente [MACHADO, 1997].

Figura 4: Ponto $P$ e suas projeções $\left(P_{E}\right.$ e $\left.P_{D}\right)$ relativas aos centros de projeção esquerdo $(C P E)$ e direito $(C P D)$.

Figura 5: Protótipo do dispositivo háptico HapticMaster com 6DOF [TSUKUBA, 2002] ..... 21

Figura 6: Esquema de um braço articulado genérico e seus possíveis movimentos. ......... 25

Figura 7: Sobreposição de imagens ao mundo real para assistência durante um procedimento cirúrgico [IGS, 2002]......

Figura 8: Sistema de treinamento em artroscopia de joelho em uso [TROWBRIDGE e HOLLANDS, 1999].

Figura 9: AccuTouch - dispositivo para simulação de endoscopia comercializado pela Immersion Corporation (http://www.immersion.com).

Figura 10: I magem de um treinamento em prática de sutura sendo executado em um simulador [HALUCK et al., 1998].

Figura 11: Localização dos pontos de coleta de medula óssea em adultos: (1) osso esterno e (2) osso ilíaco.

Figura 12: A medula óssea e as células sangüíneas pelas quais é responsável pela produção.

Figura 13: 0 transplante de medula óssea alógeno.

Figura 14: 0 transplante de medula óssea autógeno. 46

Figura 15: Região de coleta da medula óssea em crianças........................................ 47

Figura 16: A agulha Illinois utilizada na coleta de medula óssea.............................. 48

Figura 17: O Simulador de Coleta de Medula Óssea e seus módulos funcionais.............. 53

Figura 18: Camadas de tecido da região pélvica. 56

Figura 19: Esquema da conexão física dos dispositivos ao computador: a imagem do monitor é sincronizada com a obturação das lentes dos óculos por intermédio de um emissor ligado à placa de vídeo; o dispositivo háptico é conectado diretamente à porta paralela do computador.

Figura 20: Plataforma de execução do simulador. 59

Figura 21: 0 dispositivo háptico Phantom Desktop. 60 
Figura 22: Conjunto composto por óculos e emissor infravermelho para visualização estereoscópica.

Figura 23: As rotinas de visualização e atuação háptica e sua comunicação com os dispositivos de entrada e saída.

Figura 24: Modelos poligonais originais.

Figura 25: Conjunto dos modelos gerados e utilizados no simulador de coleta de medula óssea com a respectiva resolução

Figura 26: Formato e definição das calotas utilizada para a simulação do toque do osso sob a pele na região das cristas ilíacas.

Figura 27: I magens utilizadas para a representação visual do dispositivo háptico

Figura 28: Diagrama da cena háptica definida no simulador de coleta de medula óssea.

Figura 29: Detalhe do menu superior do sistema com as opções de ajuste de estereoscopia visual.

Figura 30: Diagrama com a seqüência de execução dos módulos do simulador de coleta de medula óssea e as imagens da tela correspondentes.

Figura 31: Oncologista utilizando o simulador de coleta de medula óssea baseado em RV

Figura 32: Sistema de calibragem das propriedades táteis. Cada cubo vermelho na tela apresenta características físicas diferentes que podem ser percebidas com o uso do dispositivo háptico.

Figura 33: Esquema de montagem e disposição de equipamentos em uma mesa de visualização (http://magma.reachin.se).

Figura 34: Protótipo da mesa de visualização para o simulador de coleta de medula óssea.

Figura 35: Diagrama da classe CMedulaStereoView.

Figura 36: Diagrama da classe PhantomBasic.

Figura 37: Diagrama da classe HapticPuncCamada.

Figura 38: Diagrama da classe ViscEffect.

Figura 39: Diagrama das classes de visualização e atuação háptica. 


\section{Lista de Abreviaturas}

$3 \mathrm{D}$

- Tridimensional

6DOF - Six Degrees of Freedom ou Seis Graus de Liberdade

CPD - Centro de Projeção Direito

CPE - Centro de Projeção Esquerdo

DP-FMUSP - Departamento de Pediatria da Faculdade de Medicina da Universidade de São Paulo

GHOST - General Haptic Open Software Toolkit

HMD - Head Mounted Display

LSI-EPUSP - Laboratório de Sistemas Integráveis da Escola Politécnica da Universidade de São Paulo

Phantom - Personal Haptic Interface Mechanism

PC - Personal Computer ou Computador Pessoal

SRV - Sistema de Realidade Virtual

RV - Realidade Virtual

VRML - Virtual Reality Modeling Language ou Linguagem de Modelagem de Realidade Virtual 
"Um caminho de mil quilômetros

começa com o primeiro passo."

Lao Tse

1 Introdução 


\subsection{Apresentação}

Sistemas de simulação de procedimentos para a medicina baseados em realidade virtual permitem o estudo e observação de forma realista de casos específicos, novas técnicas e metodologias. Para tanto, esses sistemas podem oferecer desde uma visualização tridimensional de modelos reconstruídos a partir de imagens reais até uma interação baseada no toque dos objetos (órgãos ou outras estruturas) virtuais.

Este trabalho relaciona-se com a pesquisa de sistemas de realidade virtual para apoiar procedimentos médicos invasivos em oncologia pediátrica. A pesquisa integra um estudo de caso em transplante de medula óssea, com a modelagem e desenvolvimento de um simulador de coleta de medula óssea para pediatria. Para tal, conta com um programa de colaboração científica entre o Laboratório de Sistemas Integráveis da Escola Politécnica da Universidade de São Paulo (LSI-EPUSP) e o Departamento de Pediatria do Hospital das Clínicas da Faculdade de Medicina da Universidade de São Paulo (DP-FMUSP) no desenvolvimento desta pesquisa.

\subsection{Motivação}

A Realidade Virtual é uma área do conhecimento que oferece inúmeras oportunidades de investigação científica e inovação tecnológica. Sistemas de realidade virtual para treinamento e planejamento de procedimentos em medicina têm sido alvo de pesquisas em todo o mundo [WESTWOOD et al., 1999/2000/2001/2002] e o Brasil começa a ampliar suas pesquisas e verificar a potencialidade de aplicações que essa ciência pode oferecer à sociedade [MACHADO et al., 2001a] [GÓES et al., 2001] [MACHADO et al., 2000b] [GÓES et al., 2000] [COHEN et al., 1999].

Nos últimos anos, com o surgimento dos procedimentos conhecidos como minimamente invasivos, métodos cirúrgicos passaram a oferecer um tempo 
menor de recuperação para os pacientes, com a conseqüente diminuição do tempo de permanência destes pacientes no ambiente hospitalar. Nesse tipo de procedimento, o médico/cirurgião realiza pequenos cortes (aproximadamente $10 \mathrm{~mm}$ ) por onde são inseridos os instrumentos cirúrgicos no corpo do paciente. Em alguns casos não existe informação visual para o médico e de sua habilidade dependerá o sucesso do procedimento. Em métodos dessa natureza, bem como outros tantos da área médica, sabe-se que tradicionalmente os médicos novatos treinam com cobaias e posteriormente acompanham um médico mais experiente. No entanto, o treinamento com cobaias não reproduz fielmente a anatomia ou as características dos tecidos humanos. Tanto essa forma de treinamento como o procedimento real baseiam-se em aspectos visuais e táteis que podem ser simulados em um sistema de realidade virtual. Da mesma maneira, sistemas de realidade virtual podem apresentar a anatomia da região de interesse, permitindo sua exploração e estudo.

Observa-se, portanto, que o uso de ferramentas para treinamento baseadas em realidade virtual poderia oferecer uma nova forma de treinamento, onde imagens tridimensionais, exploração interativa e informações táteis seriam combinadas para oferecer um treinamento mais realista. Assim, o uso de sistemas computacionais com essas características permitiriam 0 melhor treinamento do médico e, conseqüentemente, maior qualidade no atendimento ao paciente.

\subsection{Relevância}

A oncologia pediátrica já se constitui a $2^{\mathrm{a}}$ causa de mortalidade entre crianças de 2 a 16 anos nos grandes centros urbanos brasileiros. O DP-FMUSP atende por volta de 340 novos casos por ano [ODONE $F^{\circ}$, 2001] Pretende-se com a presente pesquisa contribuir para a qualidade de vida dos pacientes pelo uso de novos paradigmas de treinamento e ensino médico em missões críticas. Esses novos paradigmas devem permitir que o treinamento seja efetuado com 
um grau de realismo semelhante à execução do procedimento real, esteja disponível a qualquer momento, represente visual e fisicamente as estruturas anatômicas envolvidas no processo e permita uma interação confortável do usuário com o sistema. Nesse ponto, inserem-se os sistemas de simulação baseados em realidade virtual.

$\mathrm{Na}$ literatura científica internacional, até 0 momento não foram identificadas aplicações da realidade virtual em oncologia pediátrica, o que permite observar o enorme potencial de uso e impacto de sistemas de realidade virtual na prática desta modalidade médica, bem como a possibilidade de desenvolvimento de contribuições científicas inéditas.

\subsection{Objetivos}

O objetivo geral deste trabalho é investigar como sistemas baseados em realidade virtual podem apoiar a prática médica oferecendo sistemas de treinamento realistas. Pretende-se, com sistemas dessa natureza, aprimorar em um futuro próximo os atuais procedimentos de treinamento utilizados, oferecendo uma maneira realista de treinamento e dispensando o uso de cobaias ou cadáveres.

Dentro desse enfoque, serão analisados sistemas de realidade virtual existentes na área médica, dispositivos de interação, formas de interação usuário-sistema e aspectos de desenvolvimento de sistemas de simulação, bem como características específicas relacionadas ao procedimento de coleta de medula óssea para a pediatria.

\subsection{Contribuição}

O Simulador para Treinamento de Coleta de Medula Óssea desenvolvido neste trabalho é o primeiro simulador para treinamento utilizando realidade virtual implementado voltado para a pediatria. Até o presente momento não foram encontrados registros na literatura científica de sistemas similares. A 
necessidade de sistemas específicos para essa modalidade da medicina é 0 sabido fato de que crianças apresentam características físicas diferentes de adultos, como densidade óssea e elasticidade da pele, dentre outras. Isto torna-se especialmente relevante sob o ponto de vista da utilização de dispositivos hápticos, com os quais o usuário do sistema pode sentir as propriedades de tecidos, órgãos e demais objetos apresentados durante a interação com o sistema.

No Brasil, este é também o primeiro sistema de realidade virtual desenvolvido para o treinamento médico. 0 fato de ser o primeiro sistema deste tipo no país, abre as portas para inúmeras outras pesquisas diretamente relacionadas ou periféricas, como no caso do desenvolvimento de novos dispositivos e algoritmos de interação tátil.

\subsection{Trabalhos Correlatos na I nstituição}

Esse trabalho se insere na colaboração estabelecida entre o Departamento de Pediatria da Faculdade de Medicina da USP (DP-FMUSP) e o Laboratório de Sistemas Integráveis da Escola Politécnica da USP (LSI-EPUSP). Uma das pesquisas correlacionadas é o projeto de mestrado "Extração de Características em Neuroblastomas Usando Processamento Tridimensional de Imagens" que propôs o uso de técnicas de análise de imagens tridimensionais em exames de tomografia computadorizada de crianças em tratamento para a caracterização de neuroblastomas [AYRES, 2001].

Dentro do LSI-EPUSP este trabalho está inserido em um contexto maior relacionado com computação e comunicação de dados de alto desempenho aplicados à medicina. Dentre os projetos correlacionados destaca-se a rede de telemedicina onco-pediátrica que estabeleceu um teste pioneiro de telemedicina para regiões remotas do Brasil que atualmente permite a comunicação e troca de diagnóstico através de vídeo conferência entre o 
Hospital de Base Ary Pinheiro em Rondônia e o Instituto da Criança em São Paulo [VENCIGUERRA, 2000].

Acredita-se que, em um futuro não muito distante, a realidade virtual esteja inserida em sistemas de treinamento e cirurgias a distância, permitindo aos médicos, dentre outras coisas, operarem pacientes e conduzirem cirurgias a distância, além de se comunicarem com outros centros médicos por intermédio de telepresença.

\subsection{Estrutura da Tese}

Esta tese está dividida nos seguintes capítulos:

\section{Capítulo 1: Introdução}

Apresentação geral, motivação e relevância científica, objetivos, escopo do trabalho dentro do laboratório onde está sendo desenvolvido e estrutura do documento.

Capítulo 2: Estado da Arte em Realidade Virtual Aplicada à Simulação de Procedimentos Médicos Invasivos

Revisão da literatura envolvida na pesquisa: realidade virtual, simuladores para a medicina, diferenciação entre os procedimentos invasivos existentes: treinamento, planejamento e assistência, dispositivos hápticos e plataformas de visualização estereoscópica.

Capítulo 3: Análise e Requisitos para a Simulação de Procedimentos Invasivos em Oncologia Pediátrica.

Apresentação da oncologia pediátrica e de procedimentos invasivos.

Análise de requisitos para um sistema de treinamento em oncologia pediátrica baseado em realidade virtual.

Proposta de um sistema de treinamento. 
Capítulo 4: Projeto e Implementação de um Simulador para Treinamento em Coleta de Medula Óssea.

Apresentação do simulador com a descrição funcional dos módulos do sistema e de seus componentes.

Descrição de aspectos de implementação do simulador e do método de calibragem das propriedades físicas para a interação háptica.

\section{Capítulo 5: Análise e Avaliação dos Resultados}

Apresenta uma análise comparativa entre 0 método proposto e 0 método tradicional de treinamento, além de analisar o simulador desenvolvido em relação a outros sistemas presentes na literatura.

Análise dos resultados obtidos e apresentação de uma primeira avaliação feita pela comunidade médica.

Discussão sobre possíveis aprimoramentos para o simulador.

\section{Capítulo 6: Conclusão e Trabalhos Futuros}

Considerações sobre o problema apresentado, proposta de trabalhos futuros e conclusões. 
2 Estado da Arte em Realidade Virtual aplicada à Simulação de Procedimentos Médicos Invasivos 


\subsection{Introdução}

A Realidade Virtual torna-se cada vez mais presente em sistemas computacionais e apresenta vantagens quando utilizada para simular situações reais em diferentes áreas do conhecimento [HAASE et al., 1996] [HODGES et al., 1995] [MACHADO, 1997] [VINCE, 1995].

O objetivo deste capítulo é apresentar os conceitos e o estado da arte relacionados à Realidade Virtual e à simulação de procedimentos médicos invasivos. Outros conceitos importantes relacionados ao desenvolvimento de sistemas de realidade virtual voltados para a medicina também serão abordados: sistemas de exibição de imagens estereoscópica, dispositivos hápticos, modelagem física e deformação de objetos. Finalmente, serão expostas as características de sistemas de simulação de procedimentos invasivos em medicina com a apresentação de sistemas encontrados na literatura.

\subsection{Realidade Virtual}

Em 1991, Howard Rheingold escreveu sobre uma tecnologia revolucionária chamada Realidade Virtual [RHEINGOLD, 1991]. Essa nova tecnologia referia-se a mundos artificiais gerados por computador e a dispositivos eletrônicos sofisticados e prometia transformar a sociedade. A Realidade Virtual ganhou fama através dos filmes de ficção científica mas, devido ao elevado custo e restrições tecnológicas, manteve por vários anos sua aplicação restrita a jogos e pesquisas na indústria da guerra. Com o desenvolvimento de novas tecnologias e dispositivos, a Realidade Virtual passou a ser utilizada em diferentes áreas do conhecimento [NETTO et al., 2002].

Entendemos a Realidade Virtual (RV) como uma ciência que engloba conhecimento de diversas áreas, como a computação, eletrônica, robótica e cognição, dentre outras, visando oferecer sistemas computacionais que 
integram características de imersão e interatividade para simular ambientes reais onde os usuários têm estimulados simultaneamente os seus vários sentidos pelo uso de dispositivos específicos.

A utilização de dispositivos de interação e imersão utilizados em sistemas de RV está diretamente associada aos aspectos cognitivos do ser humano e pode explorar estímulos visuais, auditivos, táteis, motores e olfativos [ROSEMBLUM et al., 1998]. Esses dispositivos dividem-se em dois grupos: entrada e saída.

Os dispositivos de entrada são responsáveis pelo envio de informações de interação ou movimentação do usuário com o sistema. Essas informações são utilizadas para o processamento de uma nova cena gráfica ou outra informação resultante da ação do usuário. Nesse grupo encontram-se: os sensores de trajetória, responsáveis por detectar a posição do objeto ou parte do corpo ao qual estão acoplados; os dispositivos de interação, como as luvas de dados (utilizadas no reconhecimento dos movimentos da mão) e as bolas isométricas para movimentação com 6DOF (seis graus de liberdade); e os sensores biológicos, que usam reconhecimento de voz ou sinais elétricos musculares [MACHADO, 1995].

Os dispositivos de saída visam o estímulo dos sentidos do usuário, enviando para ele as respostas do sistema. Nesse grupo encontram-se os dispositivos visuais, auditivos, físicos e de locomoção.

Pelo fato de uma grande porção do cérebro ser dedicada ao processamento das informações visuais [ACKERMAN, 1990], os dispositivos visuais e o tipo de imagem gerada pelo sistema de RV têm forte influência no nível de imersão do usuário. Os dispositivos visuais utilizados em RV podem ser monoscópicos ou estereoscópicos permitindo ou não a visualização das imagens apresentadas em três dimensões. No caso dos dispositivos estereoscópicos cada exibição de imagem de uma cena é processada duas vezes. A distância existente entre os olhos humanos é utilizada para esse processamento que resulta em duas imagens ligeiramente diferentes. Quando visualizadas individualmente por cada olho, essas imagens são reunidas no cérebro e resultam em uma visualização 
tridimensional. Exemplos de dispositivos visuais são os video-capacetes, os head-coupled displays (visores montados sobre um braço mecânico com sensores de movimentação), os monitores convencionais ou autoestereoscópicos e os sistemas de projeção. No caso dos sistemas de projeção, estes são compostos por óculos polarizadores, obturadores ou de filtros coloridos que permitem a visualização estereoscópica em monitores ou telas [MACHADO, 1995].

Outros dispositivos de saída são: os auditivos, sistemas de som 3D responsáveis pela exibição dos sons; as plataformas móveis, que interferem no equilíbrio do corpo e são utilizadas em simuladores de vôo e jogos eletrônicos; e os dispositivos físicos. Neste último caso, os dispositivos estimulam as sensações físicas por meio do retorno de forças, de sensações de toque e de temperatura [NETTO et al., 2002].

Assim, Sistemas de Realidade Virtual (SRV) permitem que usuários visualizem, interajam e movimentem-se em três dimensões em um ambiente gerado em tempo-real pelo computador [BROOKS, 1999]. Diferente dos sistemas computacionais convencionais, nos SRVs as informações recebidas pelo computador podem ser movimentos capturados do usuário por meio de dispositivos de leitura tridimensional associados a alguma parte do seu corpo ou outros sensores de movimento; o processamento das informações é feito em tempo-real e as respostas fornecidas ao usuário podem ocorrer por meio de dispositivos físicos, imagens tridimensionais ou sons [MACHADO, 1995].

O grau imersão e a interatividade influenciam o nível de realismo de um SRV e são determinados pela qualidade dos gráficos apresentados, pelo desempenho dos dispositivos que apresentam esses gráficos e pelo desempenho do sistema computacional no processamento dos gráficos e processos relacionados aos dispositivos de rastreamento de posição [BROOKS, 1999]. Outras tecnologias importantes para a RV estão relacionadas à sintetização de som, apresentação de reações por meio de dispositivos físicos, desenvolvimento de dispositivos específicos de interação e de técnicas de interação [BROOKS, 1999]. 
SRVs têm sido utilizados para os mais diversos fins, como a simulação de missões críticas na medicina [SORID e MOORE, 2000], modelagem e testes de colisão na indústria automobilística [MAHONEY, 1995], estudo de moléculas [HAASE et al., 1996], entretenimento, tratamento de fobias [HODGES et al., 1995], simulação do comportamento de satélites no espaço [MACHADO, 1997] e treinamento de pilotos na aviação civil [VINCE, 1995]. A Figura 1 mostra 0 simulador de vôo do Boeing 777 composto por uma plataforma móvel onde pilotos podem treinar decolagens e aterrissagens com ambientes que simulam aeroportos de diversos países, além de situações de emergência.

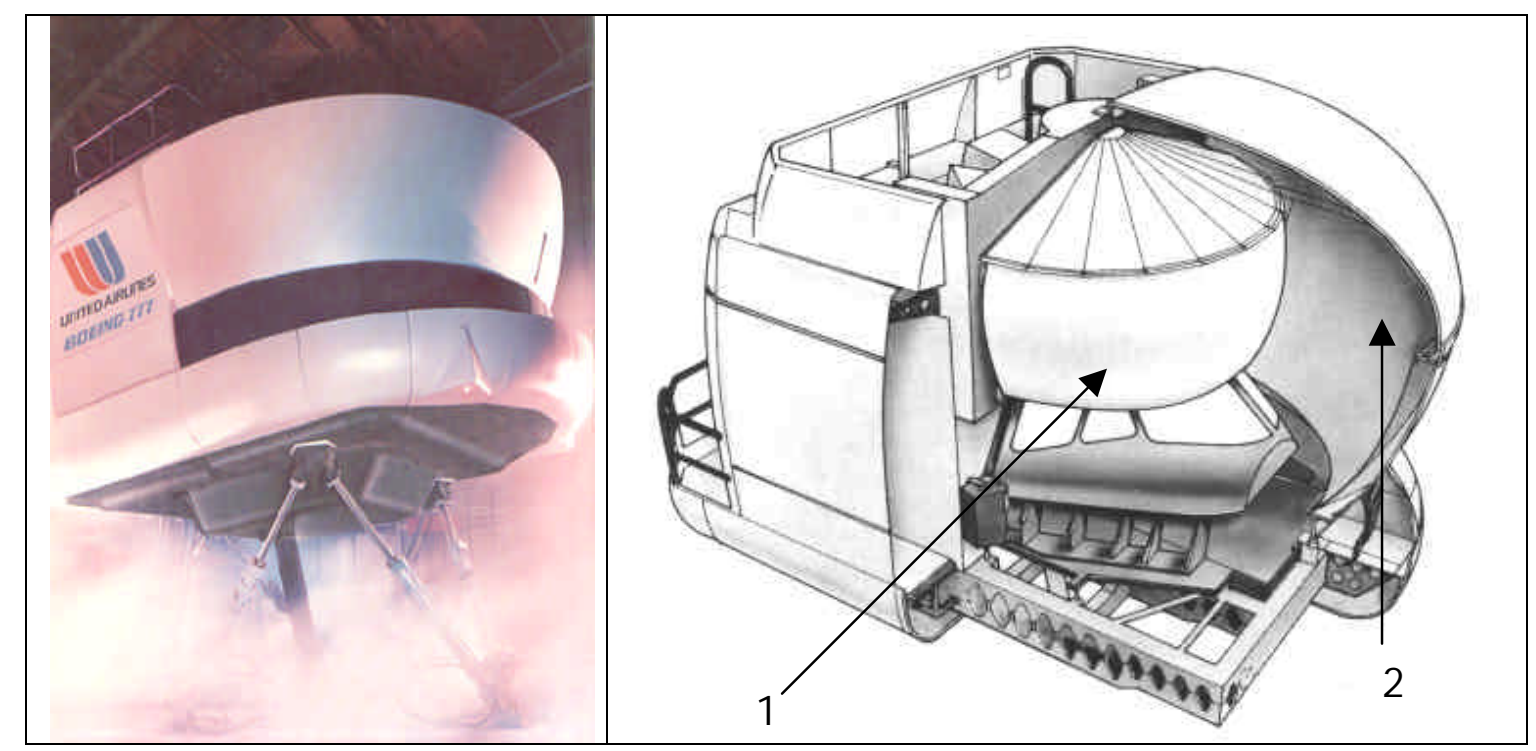

Figura 1 : Visão externa e interna do simulador de vôo do Boeing 777. Na visão recortada observa-se o sistema de exibição (1) sobre a cabine e o espelho esférico (2) que a envolve refletindo a imagem exibida para o piloto [Vince, 1995 p.340].

\subsubsection{Histórico}

Os desenvolvimentos que deram origem aos sistemas de realidade virtual começaram nos Estados Unidos com a construção de simuladores de vôo após a Segunda Guerra mundial. A indústria do entretenimento também teve um papel bastante importante no surgimento da realidade virtual com o simulador Sensorama em 1956: uma espécie de cabine onde filmes 3D eram projetados e 
combinados com som estéreo, vibrações mecânicas, aromas e ar movimentado por ventiladores, fornecendo ao usuário/participante uma viagem multisensorial [VINCE, 1995].

Em 1963, I van Sutherland publicou sua tese de doutorado e descreveu como os computadores poderiam ser usados para exibir gráficos interativos. Mais tarde ele apresentou o primeiro video-capacete que permitia ao seu usuário a visualização de um gráfico, representado em estrutura de arame, através de pequenos monitores de tubo de raios catódicos posicionados diretamente diante dos olhos [SUTHERLAND, 1965]. A partir de então, as pesquisas se intensificaram e em 1982 os simuladores de vôo da força aérea americana já utilizavam video-capacetes com integração de áudio e vídeo e permitiam movimentos com seis graus de liberdade [PIMENTEL e TEIXEIRA, 1995].

A primeira luva de dados, dispositivo capaz de capturar os movimentos da mão e inclinação dos dedos do usuário e transmiti-los ao computador, surgiu comercialmente em 1985. Em 1986 a NASA possuía um ambiente virtual que permitia aos usuários ordenar comandos de voz, escutar fala sintetizada e som $3 \mathrm{D}$, além de manipular objetos diretamente com os movimentos das mãos utilizando luva de dados [MACHADO, 1995].

Diversas pesquisas, como as mencionadas acima, levaram à conscientização de que produtos de realidade virtual podiam ser comercializáveis, o que ocasionou a criação de empresas de equipamentos e sistemas para realidade virtual e deu início a diversos programas de pesquisa nessa área no mundo inteiro. Em 1989, a empresa Autodesk Inc. apresentou o primeiro sistema de realidade virtual baseado em um computador pessoal [PIMENTEL e TEIXEIRA, 1995].

Atualmente, com o desenvolvimento tecnológico dos últimos anos, a realidade virtual está sendo utilizada para os mais diversos fins nas diversas áreas da ciência, sendo que na última década aplicações médicas utilizando realidade virtual passaram a ser desenvolvidas, tornando essa área comercialmente e clinicamente importante em termos de tecnologia aplicada à medicina [SZÉKELY e SATAVA, 1999]. 


\subsection{Exibição de I magens Estereoscópicas}

Uma grande área do cérebro é dedicada ao processamento e organização dos estímulos visuais. Devido a isso, os dispositivos visuais e o tipo de imagem gerada por um sistema de realidade virtual influenciam o nível de imersão do sistema [PIMENTEL e TEIXEIRA, 1995].

Os sistemas de exibição estereoscópica ou 3D permitem ao observador/usuário ver os objetos ou o ambiente gerado além das dimensões da tela do computador, acrescentando profundidade à visualização e, conseqüentemente, tornando-a mais realista e próxima da forma que o mundo real é visto.

Em linhas gerais, pode-se dizer que a estereoscopia, conceito no qual esses sistemas de exibição são baseados, trabalha com o fato de que cada um dos olhos humanos, estando ligeiramente afastados um do outro, vê imagens ligeiramente diferentes. Essas imagens são reunidas no cérebro e compreendidas com características de profundidade, distância, posição e tamanho [MACHADO, 1995].

Em sistemas de exibição de imagens estereoscópicas, a distância entre as imagens esquerda e direita produzidas é chamada de paralaxe. A distância horizontal entre pontos iguais das imagens esquerda e direita de uma imagem sobreposta na retina é conhecida como disparidade [STEREOGRAPHICS, 1997b]. Assim, a paralaxe existente entre as imagens do par estereoscópico produz disparidade nos olhos, o que permite ao cérebro compreender as imagens em três dimensões [STEREOGRAPHICS, 1997b].

Existem quatro tipos de paralaxe que podem ser obtidas em sistemas estereoscópicos: zero, divergente, positiva e negativa. Em imagens com paralaxe zero, os eixos oculares cruzam-se no plano de observação. Na paralaxe divergente, os eixos oculares nunca se cruzam, sendo que isso não acontece na observação do mundo real e por isso não existe uma razão para a 
sua utilização [STEREOGRAPHICS, 1997b]. A paralaxe positiva, por sua vez, faz com que os eixos oculares cruzem-se atrás do plano de observação, fornecendo profundidade às imagens observadas. Já a paralaxe negativa permite que as imagens saltem do plano de observação, uma vez que os eixos oculares cruzam-se na frente deste. A Figura 2 mostra os quatro tipos de paralaxe.

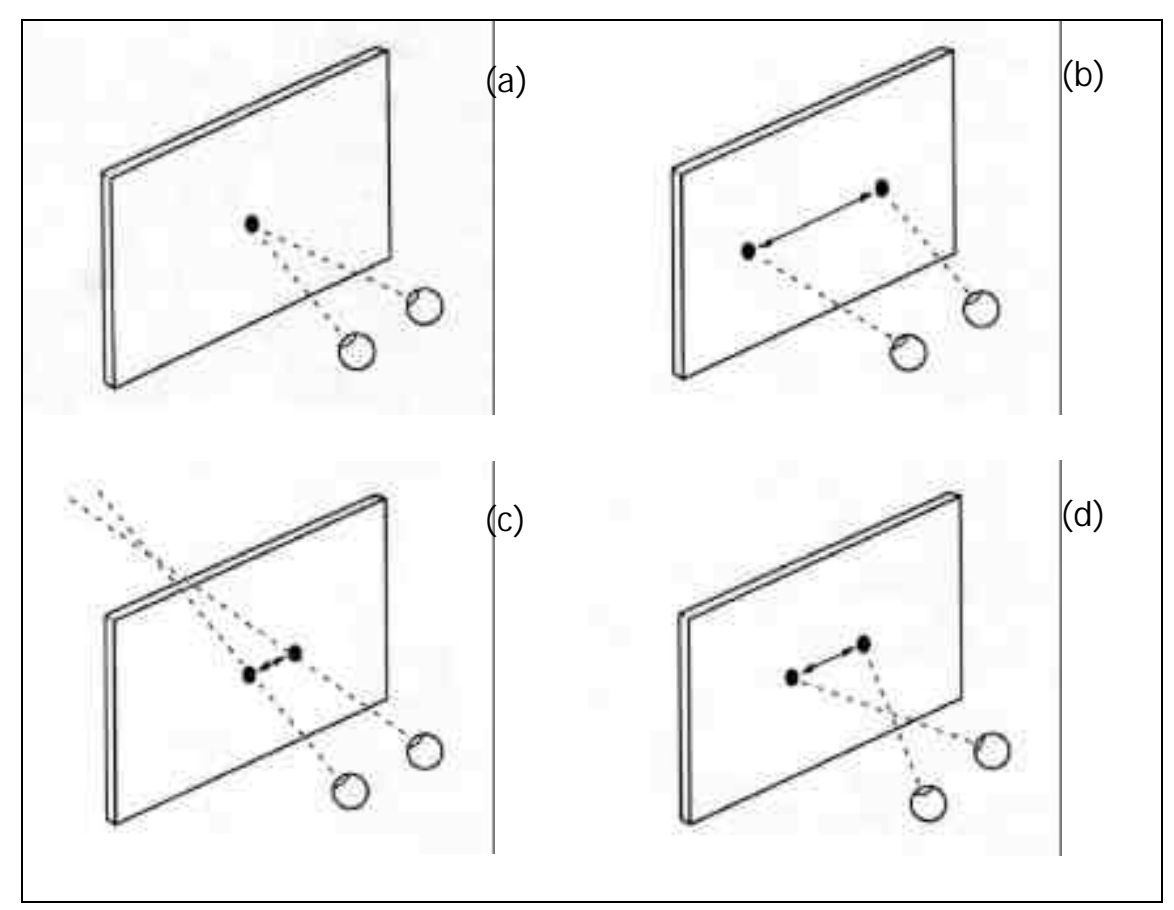

Figura 2: Os quatro tipos de paralaxe: (a) zero, (b) divergente, (c) positiva e (d) negativa.

Para a exibição estereoscópica das imagens existem diversos dispositivos utilizados, sendo que a escolha de um determinado tipo de sistema de exibição dependerá da finalidade do sistema de RV. Exemplos de dispositivos são os capacetes de visualização (Head-Mounted Displays), que geralmente integram sistemas de áudio e detecção de trajetória, e os dispositivos binoculares suspensos (head-coupled displays), que integram detecção de movimento no braço mecânico que os suporta [PIMENTEL e TEIXEIRA, 1995]. Existem ainda os sistemas baseados no uso de monitores de vídeo ou telas de projeção. Para eles existem três processos principais utilizados para a exibição de imagens estereoscópicas: anaglifo, luz polarizada ou luz intermitente. 0 processo por 
anaglifo utiliza de cores complementares, como azul e vermelho ou verde e vermelho, para a exibição de cada imagem do par estereoscópico. No processo por luz polarizada, as imagens do par estereoscópico são projetadas em planos ortogonais, e no processo por luz intermitente cada imagem do par estereoscópico é apresentada de forma alternada em uma freqüência rápida e imperceptível ao ser humano [MACHADO, 1997]. Os três métodos exigem o uso de algum tipo de dispositivo pelo usuário para a separação das imagens, como óculos de filtros, óculos obturadores (shutter glasses) ou óculos polarizadores.

Sistemas baseados no uso de monitores auto-estereoscópicos também já estão disponíveis. Esses sistemas isentam o usuário da necessidade de vestir óculos, mas ainda oferecem uma baixa resolução a um custo muito maior se comparados ao conjunto composto por um monitor convencional e óculos obturadores [KAUFMANN et al., 2000].

\subsubsection{Métodos para a Geração de Pares Estereoscópicos}

A visualização de imagens com estereoscopia é possível devido a uma etapa prévia de geração dos pares estereoscópicos. Existem três métodos para a obtenção do par estereoscópico: projeção off-axis, projeção on-axis e rotação [HODGES, 1992].

Na projeção off-axis assume-se a existência de dois centros de projeção, sendo que a visão esquerda é produzida baseada no centro de projeção esquerdo e a visão direita é produzida baseada no centro de projeção direito. Ambas as vistas são implementadas juntamente com uma transformação de visualização e podem incluir também a transformação de projeção perspectiva [HODGES, 1992].

Na projeção on-axis, ao invés de dois centros de projeção, é utilizado um único centro de projeção em conjunto com translações horizontais dos dados. Neste caso, a obtenção de cada imagem do par estereoscópico é feita através 
de três passos: translação da imagem para a direita ou esquerda (dependendo da imagem do par estereoscópico a ser gerada), projeção perspectiva, e translação da imagem para o sentido contrário da primeira translação [HODGES, 1992].

$\mathrm{Na}$ técnica de rotação para a obtenção do par estereoscópico as imagens são obtidas através da simples rotação vertical do centro de projeção (num total de 4 graus, normalmente) tornando 0 processo bastante rápido computacionalmente. No entanto, isso é bastante utilizado em projeções paralelas de cenas, uma vez que quando essa técnica é implementada juntamente com projeção perspectiva as imagens obtidas apresentam deficiências, como paralaxe vertical e distorções, que afetam a qualidade da imagem [HODGES, 1992]

A principal diferença entre os resultados obtidos pelo uso da projeção off-axis sobre a projeção on-axis está relacionada ao campo visual observado por ambos os olhos e que é até $40 \%$ maior na projeção off-axis sobre a projeção on-axis [HODGES, 1992], conforme mostra a Figura 3.

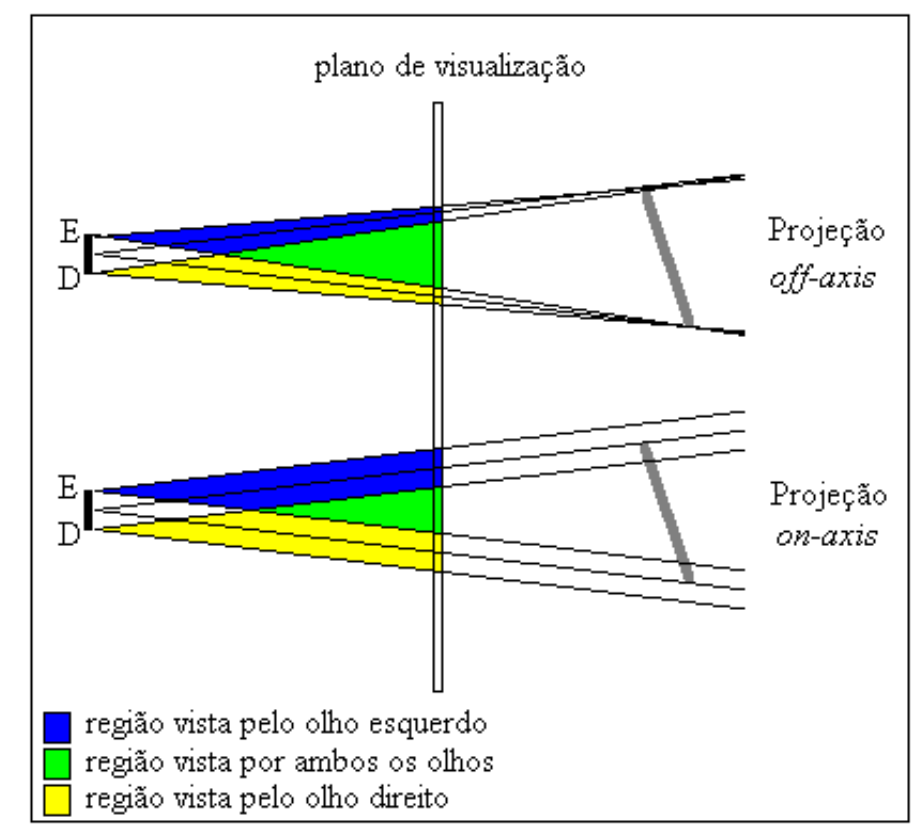

Figura 3: As projeções off-axis e on-axis, onde E e D representam os olhos esquerdo e direito, respectivamente [MACHADO, 1997]. 
$\mathrm{Na}$ projeção off-axis implementada juntamente com a projeção perspectiva [HODGES, 1992], após a transformação de visualização (3D para 2D), localizase o plano a ser visualizado paralelo ao plano $x$-y e passando pela origem. Um centro de projeção padrão (para o sistema de visualização monoscópico) é então localizado no ponto $(0,0,-d)$, onde $\mathbf{d}$ é a distância do cento de projeção ao plano de projeção. Sendo assim, a projeção de um ponto $\mathbf{P}=(x, y, z)$ passa a ter as coordenadas $\left(x_{p}, y_{p}\right)$ no plano de projeção, onde:

$$
x_{p}=\frac{x d}{d+z} \quad \text { e } \quad y_{p}=\frac{y d}{d+z}
$$

Para a produção das imagens do par estereoscópico na técnica off-axis é necessária a utilização de dois centros de projeção, um centro de projeção para a visão direita (CPD) e outro para a visão esquerda (CPE) alinhados horizontalmente. O CPD é movido perpendicularmente ao eixo $Z$ para a posição $(e / 2,0,-d)$ e o CPE para $(-e / 2,0, d)$, onde "e" representa a separação total entre os centros de projeção (Figura 4).

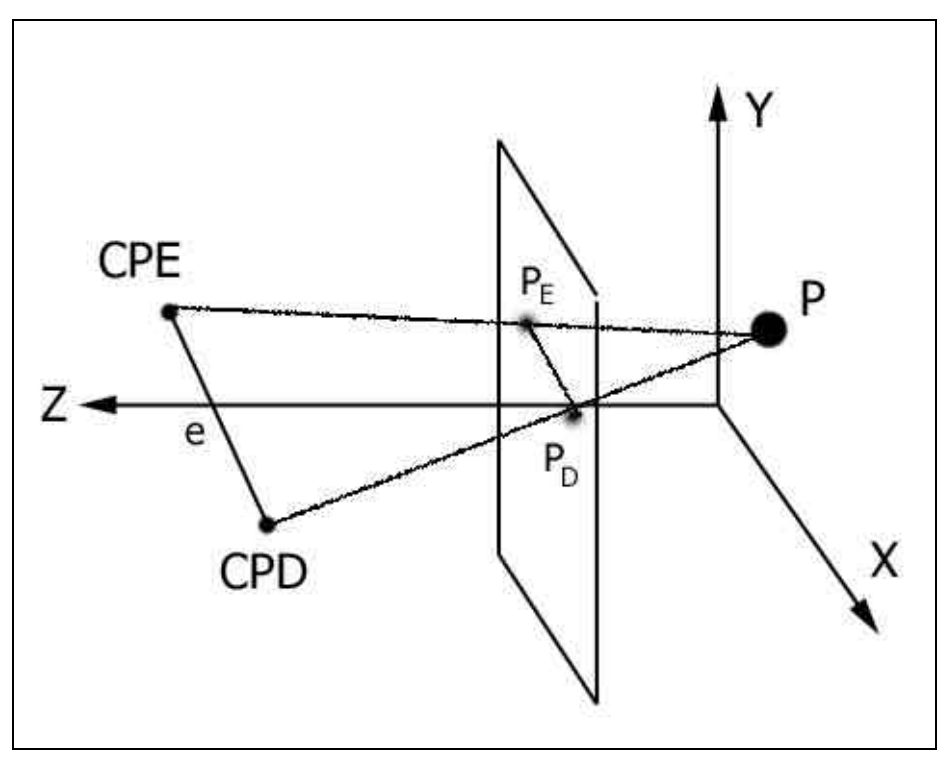

Figura 4: Ponto $\mathrm{P}$ e suas projeções $\left(\mathrm{P}_{\mathrm{E}}\right.$ e $\left.\mathrm{P}_{\mathrm{D}}\right)$ relativas aos centros de projeção esquerdo (CPE) e direito (CPD). 
Tem-se então, para um ponto arbitrário $\mathrm{P}=(\mathrm{x}, \mathrm{y}, \mathrm{z})$, a projeção para a visão esquerda $\mathrm{PE}=(x E, y E)$, com coordenadas no plano de projeção:

$$
x_{E}=\frac{x d-\frac{z e}{2}}{d+z} \quad \text { e } \quad y_{E}=\frac{y d}{d+z}
$$

E a projeção de $\mathrm{P}$ para a visão direita, $\mathrm{PD}=(x \mathrm{x}, \mathrm{yD})$, tem os valores de coordenadas no plano de projeção:

$$
x_{D}=\frac{x d+\frac{z e}{2}}{d+z} \quad \text { e } \quad y_{D}=\frac{y d}{d+z}
$$

\subsection{Dispositivos e Sistemas Hápticos}

Até pouco tempo atrás, a única maneira de interagir com os mundos 3D do computador era utilizando um mouse, teclado ou outro dispositivo que permitisse a navegação tridimensional. Com o advento dos sistemas hápticos agora é possível tocar os objetos do mundo 3D e senti-los, o que aumenta 0 sentido de imersão e interação do usuário, abrindo as portas da realidade virtual para explorar ainda mais a percepção humana. Dessa forma, "haptics" é o nome como é conhecida a tecnologia que permite aos sistemas de RV enviarem informações relacionadas ao sentido do tato ao usuário [SALISBURY, 1995].

Dispositivos hápticos são aqueles que incorporam sensores e atuadores, permitindo o monitoramento das ações do usuário e fornecendo-lhe sensação tátil e/ou de força. A sensação tátil está associada à natureza do contato com o objeto, como textura e temperatura, enquanto a sensação de força referese ao senso de posição e movimentação junto com as forças associadas ao movimento durante a interação com um objeto [SRINIVASAN et al., 1999]. Para isso que isso ocorra, atuadores são responsáveis pelo envio das sensações ao 
usuário [BURDEA, 1996]. A tecnologia de atuadores é bastante variada, sendo que os motores elétricos, pistões hidráulicos e bolsas pneumáticas são os tipos de atuadores mais utilizados e permitem o envio de sensação de força, temperatura e diversas propriedades táteis [BURDEA, 1996].

Os dispositivos hápticos que fornecem sensação de força podem ser divididos em duas categorias básicas: fixos (ground-based) ou móveis (body-based) [ZILLES, 1995]. Os dispositivos hápticos fixos, como os joysticks, são aqueles que estão fisicamente atrelados a uma plataforma ou superfície estável que permite o envio de reações de força ao usuário. Já os dispositivos hápticos móveis utilizam um ponto de conexão do próprio dispositivo para fornecer a reação de força e apresentam a vantagem de poderem ser portáteis na maioria das vezes, como no caso das luvas e exoesqueletos.

Atualmente já existe uma série de dispositivos hápticos que permitem manipulação com retorno tátil e/ou de força. Estes dispositivos podem permitir movimentos com diferentes graus de liberdade, suportam e reagem com diferentes valores de força, oferecem manipulação em um espaço limitado e utilizam tecnologias diversas.

O HapticMaster (Figura 5) [TSUKUBA,2002] e o Delta [DIMENSION, 2002] são exemplos de dispositivos hápticos desenvolvidos para serem utilizados sobre a mesa, ao lado do computador, e por isso são compactos. Existem também luvas de dados que podem incorporar atuadores para reação de força para as mãos [GOMEZ et al., 1995] e também para o braço do usuário [IMMERSION, 2002b]. Dentre tantos outros dispositivos, destacamos o FEELEX [IWATA et al., 2001], um equipamento composto por uma matriz de atuadores e um projetor para simular a forma de objetos virtuais, os equipamentos específicos para simulações em medicina, como o Laparoscopic Impulse Engine voltado para simulações em laparoscopia que oferece reação de força [IMMERSON, 2002a], e o Phantom, um braço mecânico compacto que permite movimentos com seis graus de liberdade e que oferece reação tátil e de força com três graus de 
liberdade em translações e também rotações [MASSIE e SALISBURY, 1994] [COHEN e CHEN, 1999].

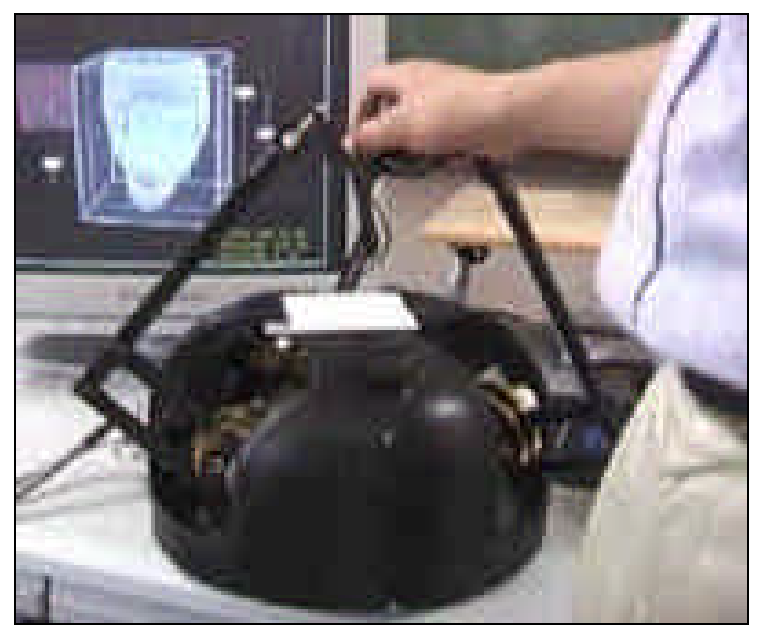

Figura 5: Protótipo do dispositivo háptico HapticMaster com 6DOF

[TSUKUBA, 2002].

A qualidade de um dispositivo háptico está relacionada a diversos itens de desempenho, sejam eles: fidelidade, pouco peso, fácil manipulação e eficiência na transmissão dos dados (força aplicadas), dentre outras [AVILA, 1999]. Além disso, o dispositivo deve ser adequado ergonomicamente à simulação e o seu custo deve ser viável comercialmente, possibilitando o seu uso além dos laboratórios de pesquisas.

Os sistemas hápticos, por sua vez, incorporam dispositivos hápticos e programas específicos para o controle destes. Esses programas podem ser descritos como uma combinação de algoritmos de controle e rotinas de computação gráfica em tempo-real [MASSIE, 1998]. Uma descrição simplificada do laço de controle interno ou laço háptico desses sistemas poderia ser: 
1. localização do cursor (dispositivo háptico) no ambiente virtual.

2. detecção das colisões entre o cursor e a geometria dos objetos virtuais.

3. cálculo do vetor de força de reação (baseado nas leis físicas definidas do ambiente virtual).

4. envio do vetor de força ao dispositivo háptico.

5. retorna ao passo 1 .

Dentre os passos citados, os mais complexos referem-se à detecção das colisões e cálculo das forças de reação, pois estes são dependentes das informações de interação monitoradas. Essas informações podem estar atreladas ao ambiente ou aos objetos que compõem esse ambiente e são especificadas durante a modelagem física.

\subsubsection{Modelagem Física}

Dispositivos hápticos permitem ao usuário sentir objetos virtuais. No entanto, eles dependem do computador ao qual estão atrelados, que permitirá 0 reconhecimento dos movimentos realizados pelo usuário e fará o cálculo das forças ou variáveis de reação enviadas ao dispositivo háptico. Para que isso ocorra é necessária uma fase conhecida como modelagem física, responsável pela determinação do comportamento dinâmico dos objetos do mundo virtual e controle do dispositivo háptico. Essa modelagem é baseada, principalmente, nas leis da física newtoniana [BURDEA, 1996].

Uma das etapas dessa modelagem física é a detecção de colisão que prevê a detecção automática de uma interação iminente entre dois objetos e o local onde isso acontece. No momento do impacto, a simulação deve fornecer uma resposta à colisão, como a deformação dos objetos, um salto, restrição ao movimento ou mesmo produzir forças e vibrações [BURDEA, 1997]. Uma vez 
que os SRVs são sistemas de tempo-real, não é possível utilizar rotinas de detecção offline, pois a trajetória de um objeto não é conhecida a priori. Outro detalhe importante diz respeito à necessidade de saber não apenas se ocorre uma colisão, mas também onde e qual é a interpenetração entre os objetos [BURDEA, 1997].

Também durante a modelagem física, informações são atreladas aos objetos tridimensionais, permitindo que o computador calcule a quantidade de força a ser refletida como resultado de uma interação com 0 modelo virtual [MAHONEY, 1997]. Então, as rotinas de detecção de colisão verificam constantemente a posição dos objetos existentes no mundo virtual (inclusive a do objeto que representa o dispositivo) reportando ao sistema a ocorrência de contato entre eles. Dependendo das variáveis lidas através do dispositivo háptico, forças e deformações são calculadas e exibidas ao usuário. Limitações físicas como atrito, inércia e gravidade também são características que podem ser acrescentadas durante a modelagem física.

Portanto, outra etapa presente na modelagem física relaciona-se à deformação dos objetos virtuais. A deformação permite representar alterações na forma dos objetos, oferecendo maior realismo à interação do usuário com o mundo virtual. Segundo Basdogan [BASDOGAN, 1999], os tipos de deformação podem ser divididos em dois grupos principais: geométricas ou baseadas na física. Nas deformações geométricas, os objetos ou o espaço ao redor do objeto tridimensional são modificados tendo como base apenas as manipulações geométricas, como vértices e pontos de controle ao redor do objeto, tendo alteradas as formas dos objetos. Já as deformações baseadas na física visam modelar a física envolvida no movimento e na dinâmica das interações. Assim, os modelos utilizados simulam o comportamento dos objetos sob 0 efeito de forças internas e externas a ele.

Apesar de deformações baseadas na física serem mais realistas, estas são também mais complexas de serem implementadas. Além disso, esse tipo de deformação não é indicado para simulações totalmente interativas e simulações 
de múltiplos objetos devido às atuais limitações de desempenho computacional [BASDOGAN, 1999].

\subsubsection{Sistemas Hápticos Baseados em Braços Articulados}

Uma vez que o toque é um importante sentido humano, sistemas hápticos baseados em braços articulados podem oferecer uma forma de interação bastante realista em simulações específicas. Esses sistemas utilizam dispositivos hápticos fixos (ground-based) que podem ser utilizados como ferramentas de interação em aplicações onde a destreza manual é um fator relevante.

Dispositivos dessa natureza podem ser utilizados de forma a imitar instrumentos reais, como ferramentas cirúrgicas, pincéis, chaves-de-fenda, etc. Neste caso, o problema da interação tratado pelo sistema háptico seria reduzido a um pequeno espaço ou um único ponto [ZILLES, 1995], o que aceleraria a execução de rotinas de detecção de colisão.

Os braços articulados utilizados como base para a criação de dispositivos hápticos possuem basicamente três engrenagens que permitem a translação de um ponto de referência nas três dimensões espaciais. Além disso é possível ainda oferecer rotação em relação aos três eixos ortogonais. A estas engrenagens são acoplados motores que permitem o registro e envio das forças aplicadas durante a interação. A Figura 6 apresenta o esquema de um braço articulado genérico: tomando a indicação 4 como pivô e ponto de rotações, os números 1,2 e 3 indicam as juntas responsáveis pelos movimentos de translação. 


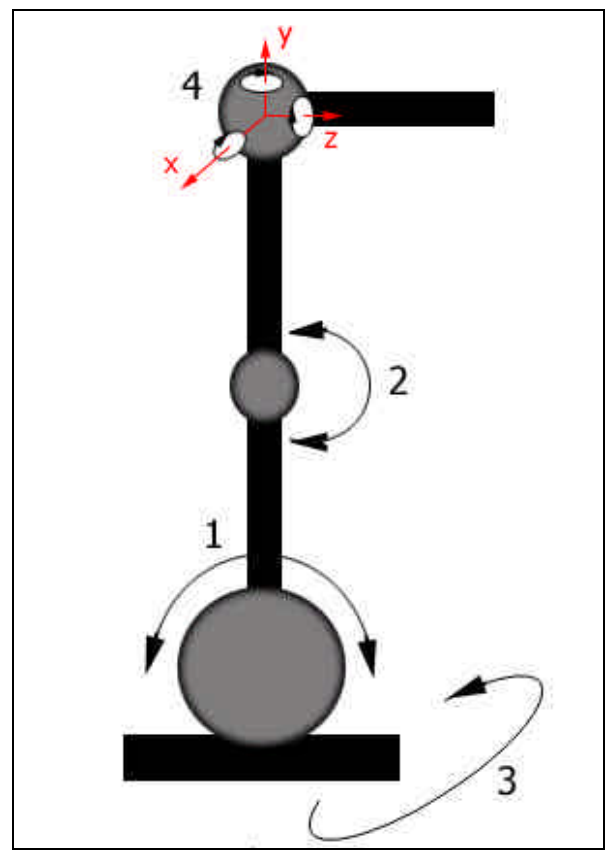

Figura 6: Esquema de um braço articulado genérico e seus possíveis movimentos.

\subsection{Modelos Deformáveis e Tecidos Moles}

Modelos dinâmicos ou modelos deformáveis são aqueles que podem apresentar deformação no tempo a partir do contato com os mesmos. Essas deformações incluem aspectos físicos do material do qual o modelo é constituído. Os fundamentos matemáticos dos modelos deformáveis representam uma reunião da teoria da aproximação, geometria e física. A geometria é utilizada para representar a forma do objeto, a física impõe restrições sobre como o objeto deve se comportar ao longo do tempo e do espaço, e a teoria da aproximação fornece o suporte teórico dos mecanismos para adaptar os modelos às suas devidas medidas [MCINERNEY e TERZOPOULOS, 1996].

Sistemas de realidade virtual voltados para a medicina podem utilizar-se de modelos deformáveis para a modelagem e representação de tecidos moles, permitindo a deformação dos mesmos durante a manipulação pelo usuário e oferecendo uma simulação mais realista. Geralmente são utilizados conceitos de 
elementos finitos ou modelos massa-mola para a geração das superfícies deformáveis por oferecem um resultado mais realista em relação à outros métodos [GIBSON e MIRTICH, 1997].

O custo computacional envolvido no processamento de deformações é bastante alto [BRO-NIELSEN et al., 1999] e por essa razão projetos que utilizam interação háptica procuram analisar o benefício resultante da implementação e execução das rotinas de cálculo de força e deformação simultaneamente [AVILA, 1999].

\subsection{Simulação de Procedimentos I nvasivos}

Em medicina, um procedimento invasivo é aquele em que 0 paciente tem parte ou região do seu corpo manipulada internamente. Nesses procedimentos o médico precisa ter experiência e saber lidar com situações adversas que possam surgir durante a intervenção.

Os procedimentos minimamente invasivos são uma nova modalidade de cirurgia que torna-se cada vez mais comum. Nesses procedimentos, também conhecidos como cirurgias endoscópicas, os instrumentos médicos são inseridos e manipulados por meio de pequenas incisões (até 10 milímetros) feitas no corpo do paciente e a visualização, quando presente, é indireta e realizada com o auxílio de micro-câmeras. Uma vantagem desse método cirúrgico é a rápida recuperação do paciente o que diminui sua permanência no hospital.

A simulação de procedimentos invasivos ou minimamente invasivos em um sistema de realidade virtual permite a prática de uma determinada técnica dentro de um ambiente onde as propriedades do organismo em questão e as sensações associadas à sua manipulação podem ser sentidas pelo usuário. Para tanto, é necessária a construção de um modelo tridimensional anatômico e a modelagem das características e comportamentos dos tecidos envolvidos.

Da mesma forma a percepção da forma do organismo pode ser feita visualmente ou pelo uso de dispositivos hápticos. Assim, também é importante 
escolher uma ferramenta de manipulação adequada ao procedimento e desenvolver rotinas gráficas e/ou de resposta tátil para a visualização e interação do usuário com o sistema. A imagem e a sensação tátil devem estar sincronizadas e o retorno de força fornecido pelo dispositivo háptico calibrado [BASDOGAN, 2000].

As características do ambiente de simulação e a sua plataforma de execução vão depender da finalidade do sistema: assistência, planejamento ou treinamento.

\subsubsection{Treinamento X Planejamento X Assistência}

Sistemas de realidade virtual aplicados a procedimentos invasivos podem ter diferentes objetivos: o treinamento, o planejamento ou a assistência.

Os sistemas de RV para o treinamento de procedimentos invasivos objetivam a incorporação de habilidades específicas, prática de novas técnicas ou estudo anatômico interativo relacionado com a anatomia e fisiologia de um determinado procedimento cirúrgico. Esses sistemas preparam estudantes tecnicamente e psicologicamente para tarefas cirúrgicas reais, simulando diferentes situações genéricas (desassociadas das peculiaridades de um paciente especifico) com alto grau de realismo. Na maioria das vezes, sistemas dessa natureza oferecem visualização estereoscópica e preocupam-se em oferecer algum tipo de retorno tátil ou visual durante a manipulação dos objetos envolvidos na simulação [SORID e MOORE, 2000].

Sistemas de RV para o planejamento de procedimentos invasivos visam a identificação dos locais de intervenção, a visualização da anatomia local, a verificação das estruturas envolvidas e pontos sensíveis envolvidos no procedimento. Para isso existem pacotes comerciais que permitem a reconstrução de volumes a partir de dados tomográficos ou obtidos por ressonância magnética de um paciente. Assim, o planejamento cirúrgico em sistemas de RV envolve o estudo da anatomia específica de um paciente, sendo 
que a construção de um modelo tridimensional adequado é a principal preocupação dos sistemas, permitindo aos médicos planejar o procedimento a ser feito de acordo com as características do paciente em questão [GUAN et al., 1998].

Os sistemas de RV para a assistência, por sua vez, utilizam-se da sobreposição de imagens geradas por computador às imagens reais para auxiliar ou prover informações relevantes durante a realização ou estudo de um procedimento, complementando a realidade [AZUMA, 1997]. Sistemas desse tipo voltados para a medicina utilizam informações e conjuntos de imagens obtidas por tomografia computadorizada ou ressonância magnética para gerar 0 volume de um órgão ou estrutura de um paciente específico. Esse volume préprocessado pode ser utilizado para auxiliar o planejamento ou execução de um procedimento com a sobreposição dos dados gerados ao mundo real. Nesse caso, os médicos visualizam o volume virtual sobreposto ao paciente e podem identificar estruturas anatômicas existentes no local de interesse, como veias, artérias ou tumores, e analisam os pontos de intervenção ou mesmo realizam um procedimento cirúrgico [GRIMSON et al., 1999]. A Figura 7 mostra um sistema de assistência sendo utilizado na realização de cirurgias.

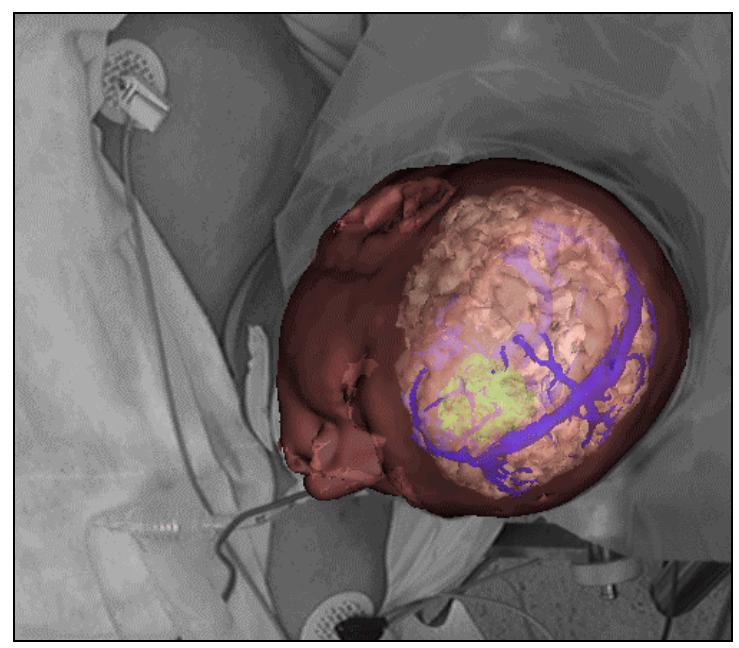

Figura 7: Sobreposição de imagens ao mundo real para assistência durante um procedimento cirúrgico [IGS, 2002]. 


\subsection{Simuladores para Medicina}

Inicialmente, os sistemas computacionais utilizando computação gráfica para a medicina visavam a reconstrução de órgãos ou partes do corpo humano para estudo da anatomia ou visualização. A realidade virtual aplicada à medicina permitiu a interação dos usuários com os objetos visualizados e a observação das propriedades destes objetos, unindo os sistemas de aquisição de imagens aos sistemas de visualização [SORID e MOORE, 2000].

Protótipos de simuladores utilizando RV passaram a ser desenvolvidos no início dos anos 90. Os primeiros simuladores visaram a visualização interativa de modelos mecânicos [DELP et al., 1990] [ROSEN et al., 1996]. Com o desenvolvimento tecnológico, resultados de processos de síntese de imagens (rendering), antes apresentados na forma de imagens estáticas ou animações pré-gravadas, passaram a ser apresentados em tempo-real. A estereoscopia também foi adicionada aos sistemas e as imagens passaram a ser observadas em estéreo. Em 1993, foi desenvolvido um simulador cirúrgico que continha um modelo computacional da anatomia humana e permitia visualização estereoscópica com o uso de um video-capacete [SATAVA 2000]. Um outro simulador para reconstrução facial foi desenvolvido em 1995 e utilizou modelos gráficos com elementos finitos para estimar as conseqüências biomecânicas de diferentes reconstruções cirúrgicas [DELP et al., 1997]. Mais recentemente, dispositivos de interação com reação tátil passaram a ser incorporados aos sistemas, permitindo ao usuário tocar e sentir as propriedades físicas das estruturas visualizadas [MAHONEY, 1997].

Assim, pode-se dizer que atualmente um simulador típico para medicina consiste de um sistema de visualização monoscópico ou estereoscópico, um computador equipado com um dispositivo para interação e um modelo físico [SORID e MOORE, 2000]. Esses sistemas são voltados principalmente para 0 planejamento cirúrgico, treinamento e educação médica. Com um simulador que utiliza realidade virtual, um médico pode aprender e praticar novas 
técnicas, planejar procedimentos complexos utilizando corpos humanos virtuais ou estudar de forma tridimensional e interativa a anatomia humana [MAHONEY, 1994]. Outra importante vantagem dos simuladores é a disponibilidade dos mesmos: o treinamento convencional depende muitas vezes do uso de cobaias ou modelos plásticos que possuem manipulação limitada, ou seja, dependendo do procedimento esses modificam suas propriedades físicas após serem manipuladas um determinado número de vezes. Por outro lado, os simuladores baseados em sistemas computacionais estão disponíveis a qualquer momento e permitem a prática de uma mesma técnica diversas vezes sem a alteração das propriedades do modelo utilizado.

Um dos grandes desafios dos sistemas de RV para medicina, no entanto, é oferecer sistemas que reproduzam exatamente aquilo que o médico vê e sente na realidade, ou seja, que forneçam uma visualização realista com imagens estereoscópicas, ofereçam o processamento dos movimentos e alterações feitas pelo usuário em tempo-real e forneçam as sensações associadas ao tato semelhantes às sentidas durante a manipulação de um tecido real [SATAVA, 2000]. Apesar dos avanços tecnológicos, a obtenção de um alto nível de realismo muitas vezes implica em sistemas de alto custo, uma vez que esses sistemas envolvem o uso de dispositivos de interação, visualização e modelos realistas com rotinas de processamento sendo executadas simultaneamente e em tempo-real, dentre outros fatores.

\subsubsection{Projetos Correlatos}

Existem diversos protótipos de simuladores de procedimentos médicos sendo desenvolvidos em todo mundo [WESTWOOD et al., 1999] [WESTWOOD et al., 2000] [WESTWOOD et al., 2001] [WESTWOOD et al., 2002]. No entanto, o desenvolvimento destes simuladores envolve uma série de requisitos computacionais difíceis de serem todos agregados em um único sistema. Dessa forma, cada projeto de simulador apresenta e aborda um ou mais pontos específicos na sua implementação, considerando a importância de cada um. 
Estes pontos específicos podem ser: detecção de colisão entre objetos, deformação dos modelos, aspectos de visualização, desempenho computacional, simulação de forças com retorno tátil, custo do sistema, reconstrução volumétrica a partir de dados reais, avaliação objetiva do procedimento, avaliação do usuário e ergonomia.

Em 1994, o Institut National de Rechercher em Informatique et Automatique (INRIA) da França publicou um relatório sobre seu protótipo de simulador de cirurgia craniofacial [DELINGETTE et al., 1994]. O objetivo do protótipo era permitir a manipulação de estruturas cranianas para correção de deformações com o uso de uma luva de dados acoplada a um sistema de rastreamento de posição. Assim, o usuário poderia "desmontar" as estruturas ósseas e remodelá-las visualizando 0 resultado final. 0 foco de atenção no desenvolvimento do simulador concentrava-se na geração e manipulação das estruturas modeladas por malhas de triângulos. A visualização no entanto, era restrita e feita através de anaglifos. Assim como a cirurgia craniofacial, outras modalidades médicas também ganharam protótipos que utilizam realidade virtual. Algumas dessas modalidades são apresentadas a seguir.

$\mathrm{Na}$ artroscopia, convencionalmente utiliza-se para o treinamento modelos plásticos e a observação de cirurgiões experientes em prática. Sistemas de simulação para essa modalidade são capazes de fornecer um treinamento baseado em imagens geradas por computador e permitir a manipulação dos instrumentos médicos, imitando uma cirurgia real. Os modelos tridimensionais da anatomia utilizados na visualização podem ser obtidos a partir de imagens de ressonância magnética ou digitalização e as ferramentas médicas podem ser modeladas em pacotes gráficos comerciais [ZIEGLER, et al., 1995] [MERL, 1999]. A movimentação das ferramentas durante a simulação pode ser detectada por rastreadores de posição que alimentam o sistema com os movimentos do usuário. Sistemas desse tipo são encontrados para treinamento de artroscopia de joelho [MERL, 1999] [TROWBRIDGE e HOLLANDS, 1999] [ZIEGLER et al., 1995] [MIAS, 1998] [SHERMAN et al., 1999] [MABREY et al., 
2000] e de ombro [SMITH et al., 1999], sendo que a principal diferença entre esses projetos é a forma e interação do usuário com o sistema e a qualidade das imagens. A avaliação feita por médicos de alguns desses protótipos demonstrou que a interação oferecida não é realista, e que existe a necessidade do uso de algum dispositivo que permita aos usuários sentirem o toque durante a interação, pois os médicos tendem a se concentrar mais nos aspectos táteis que nos aspectos visuais durante a execução desse procedimento [SHERMAN et al., 2001]. A Figura 8 apresenta um simulador de artroscopia para treinamento médico em uso.

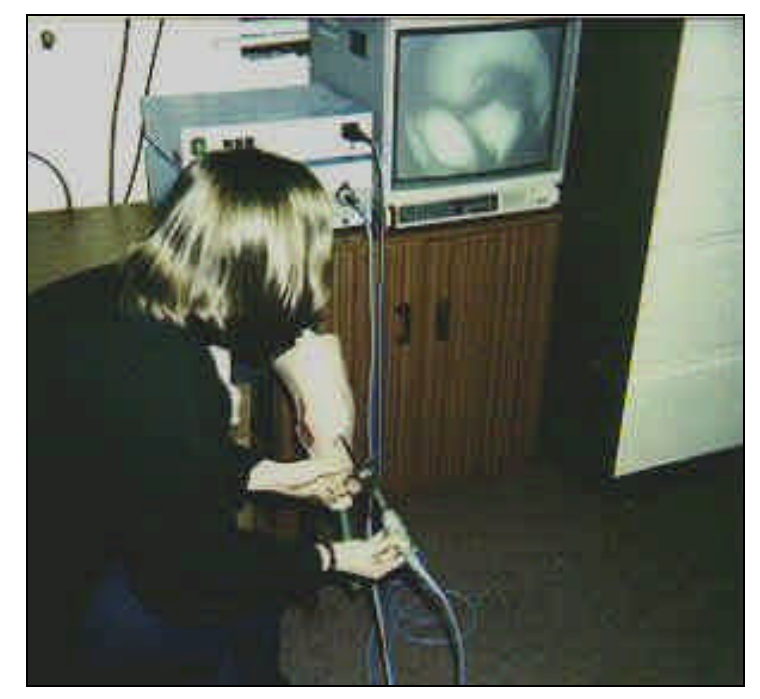

Figura 8: Sistema de treinamento em artroscopia de joelho em uso [TROWBRIDGE e HOLLANDS, 1999].

No caso dos simuladores de endoscopia, a maioria dos protótipos encontrados na literatura têm como foco principal a representação da deformação dos órgãos [YAGEL et al., 1996] [KÜHNAPFEL et al., 2000]. Assim, imagens obtidas por ressonância magnética são utilizadas para a reconstrução dos modelos tridimensionais com o método de elementos finitos ou com malhas com dinâmica massa-mola [GIBSON e MIRTICH, 1997]. Durante a simulação, 0 usuário pode sentir e visualizar a passagem do endoscópio. Equipamentos como o AccuTouch (Figura 9) são próprios para essa finalidade e fornecem 
retorno tátil. Uma característica dos simuladores de endoscopia é que eles podem ser expandidos para diferentes aplicações, como broncoscopia, colonoscopia, ureteroscopia, etc. desde que gerados os modelos tridimensionais adequados, fator que viabilizaria os custos de um produto comercial [BRONIELSEN et al., 1999]. Uma característica interessante do simulador PreOp ${ }^{T M}$ desenvolvido pela empresa HT Medical Systems Inc. é a idéia de simulação multimídia, pois o sistema também inclui vídeos e explicações teóricas, dividindo o ensino da técnica em etapas [BRO-NIELSEN et al., 1999]. No entanto, a complexidade e a qualidade dos gráficos apresentados e as deformações a serem executadas em tempo-real estão condicionadas à capacidade de processamento, fator que pode ser observado em simuladores de endoscopia como determinante para o uso de máquinas de alto desempenho [SZÉKELY et al., 1999] [BRO-NIELSEN et al., 1999].

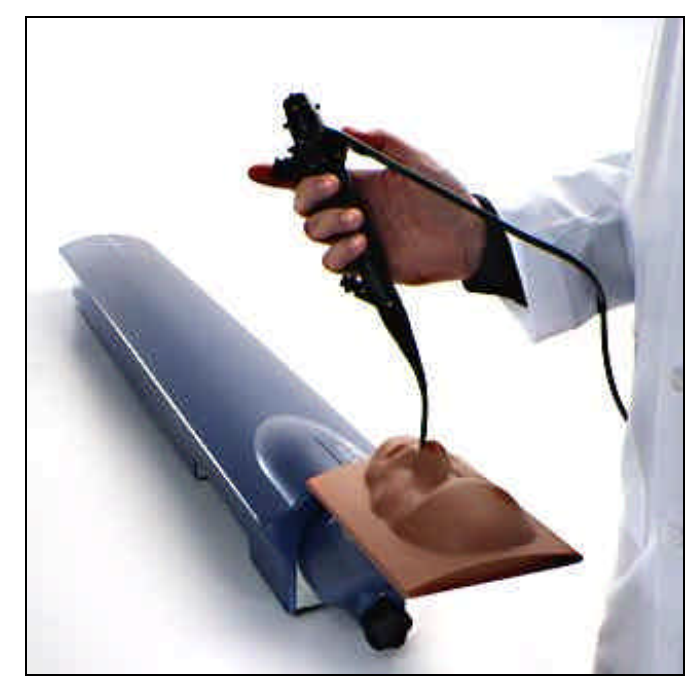

Figura 9: AccuTouch - dispositivo para simulação de endoscopia comercializado pela Immersion Corporation (http://www.immersion.com).

Pensando nas possibilidades que poderiam surgir com a pesquisa de sistemas de realidade virtual em treinamento médico, a modelagem do olho humano dentro de um ambiente virtual foi feita em 1994 a partir de computação gráfica, incluindo a representação de todas as estruturas periféricas dos olhos, como 
veias e cílios [SAGAR et al., 1994]. Nesse sistema a visualização era estereoscópica e fazia uso de óculos obturadores (shutter glasses). Na época em que foi desenvolvido, o alto grau de detalhamento e as deformações implementadas exigiram o uso de uma estação de alto desempenho. 0 objetivo final do projeto era permitir a sua utilização para a manipulação de robôs que realizam cirurgias oftalmológicas [HUNTER et al., 1995]. Assim como esse projeto, outros também abordaram a manipulação da estrutura do olho como primeiro desafio para o desenvolvimento de simuladores de cirurgias oculares mais específicas e contaram com a avaliação de especialistas quanto à qualidade e necessidades do sistema [MAHONEY, 1998]. Preocupações como a necessidade do uso de equipamentos de manipulação com retorno de força, posicionamento do usuário frente ao sistema e visualização estereoscópica são um fator comum nesses projetos que pretendem, a partir de um protótipo, utilizar em um futuro próximo a simulação com realidade virtual para 0 treinamento e desenvolvimento de novas técnicas e instrumentos [MAHONEY, 1998] [PEIFER, 1999] [SCHILL et al., 1999] [MAYR, 2001].

Outra modalidade médica contemplada com sistemas de realidade virtual para treinamento é a ortopedia. Protótipos visando esse tipo de treinamento objetivam o estudo e memorização de técnicas como colocação de implantes, colocação de pinos em fraturas e artoplastias, dentre outros. Os modelos utilizados podem ser criados com o auxílio de pacotes gráficos. Algumas das vantagens desses simuladores são a possibilidade de criação de estruturas ósseas compatíveis com cada uma das diferentes etnias existentes e a múltipla utilização de um mesmo modelo sem custos adicionais, custos estes existentes no treinamento tradicional onde os modelos ficam inutilizados após um número determinado de manipulações [SOURIN et al., 2000] [TSAl et al., 2001].

O ensino de técnicas baseadas em laparoscopia também é um foco de pesquisas para o desenvolvimento de simuladores. 0 principal objetivo atualmente é validar a utilização desses sistemas para o ensino da colocação do laparoscópio e sua manipulação. Posteriormente pretende-se empregar a 
tecnologia no ensino de técnicas específicas [OPPENHEIMER et al., 2000]. Dispositivos comerciais para sistemas de simulação em laparoscopia já estão disponíveis e são utilizados em sistemas que apresentam os órgãos e instrumentos modelados graficamente. Os modelos são geralmente extraídos de imagens de tomografia computadorizada, ressonância magnética ou seqüências de vídeo. No caso dos órgãos, eles geralmente permitem deformação quando tocados pelos instrumentos virtuais, e as rotinas de detecção de colisão oferecem algum tipo de retorno visual da colisão ao usuário [VOSS et al., 2000] [HALUCK et al., 2001].

Outros exemplos de modalidades contempladas com simuladores baseados em realidade virtual são: exame de toque para detecção de câncer de próstata [BURDEA et al., 1998], prática de sutura (Figura 10) [WEBSTER et al., 2001] [HALUCK et al., 2000], detecção de tumores subcutâneos [DINSMORE et al., 1997], planejamento de cirurgias maxilofaciais [SCHUTYSER et al., 1999] e planejamento de neurocirurgias [GUAN et al., 1998].

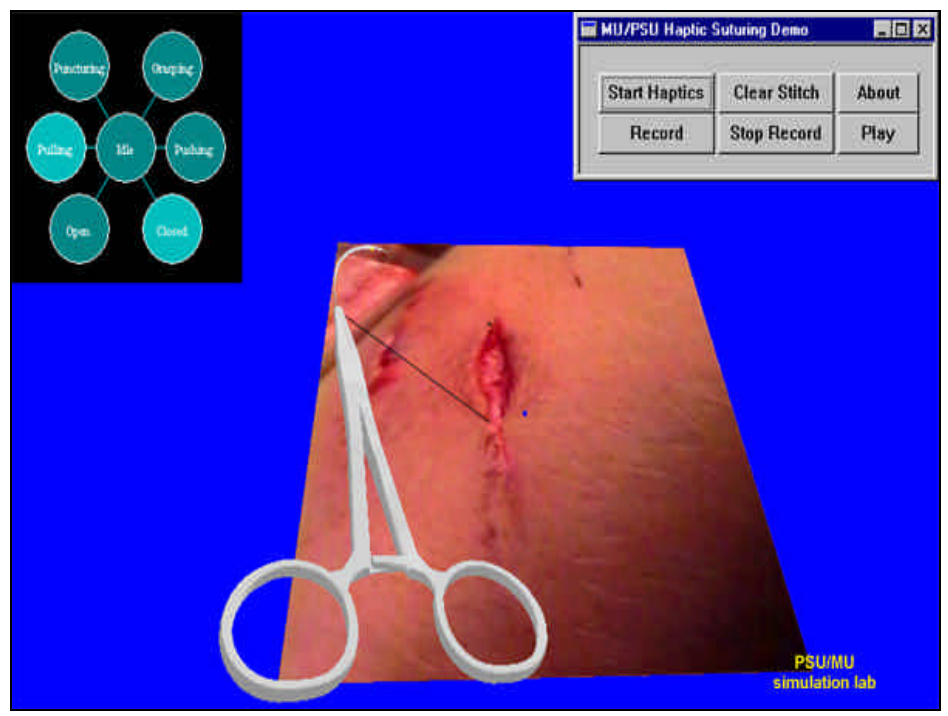

Figura 10: I magem de um treinamento em prática de sutura sendo executado em um simulador [HALUCK et al., 1998]. 


\subsection{Conclusão}

Neste capítulo foi possível descrever os principais conceitos relacionados ao estado da arte aplicado a sistemas de realidade virtual para simulação de procedimentos invasivos em medicina, bem como a apresentação de dispositivos utilizados nessas simulações. A escolha e utilização de determinados dispositivos e a incorporação de características como deformação de tecidos, bem como a plataforma computacional utilizada, dependerão das necessidades e finalidade do sistema, uma vez que estes fatores influem no seu custo e afetam o seu desempenho final. 
3 Análise e Requisitos para a Simulação de Procedimentos Invasivos em Oncologia Pediátrica 


\subsection{Introdução}

Apesar da intensificação das pesquisas em sistemas de RV voltados para o treinamento na medicina, ainda não existem sistemas de simulação baseados em RV voltados para a oncologia pediátrica. A necessidade de sistemas específicos para essa área deve-se ao fato do corpo de crianças apresentarem características diferentes do corpo adulto.

Neste capítulo são apresentados de uma forma geral os principais procedimentos invasivos cuja existência de um sistema para treinamento é de interesse do Departamento de Pediatria da FMUSP (DP-FMUSP): biópsia, transplante de medula óssea e transplante de fígado. Dessa forma, são tecidas considerações sobre cada um dos três procedimentos a fim de estabelecer os principais requisitos que devem ser incorporados a um simulador de treinamento.

Finalmente, é apresentada uma proposta inédita para o treinamento em oncologia pediátrica, detalhando o transplante de medula óssea.

\subsection{O que é Oncologia Pediátrica}

Câncer é o resultado de uma série de alterações nos genes que controlam o crescimento e o comportamento celular. Essas alterações fazem com que as divisões celulares gerem células anormais. Cada tipo de câncer tem sua própria causa, história natural e tratamento. A ocorrência e a falta de controle das alterações gênicas que resultam no câncer são objeto de intensas pesquisas médicas em todo o mundo [GUYTON e HALL, 1997].

A oncologia pediátrica é o ramo da medicina que trata do câncer em crianças. 0 câncer é a principal causa de morte de crianças abaixo de 15 anos em vários países do mundo e no Brasil atinge de 10 a 12 mil crianças por ano, sendo a $2^{\text {a }}$ causa de mortalidade infantil nos grandes centros [MELLO, 2001]. 


\subsection{Procedimentos Invasivos em Oncologia Pediátrica}

Em medicina um procedimento é chamado de invasivo quando existe a penetração ou incisão por meio de um instrumento em um organismo ou parte dele [HOUAISS, 2001].

Nesta seção serão descritos os três procedimentos invasivos de interesse para o desenvolvimento de um sistema de treinamento, segundo verificado junto ao DP-FMUSP, e o modo de treinamento convencional e atualmente utilizado para a formação ou aperfeiçoamento de médicos nessas modalidades.

\subsubsection{Biópsia}

Biópsia é o nome pelo qual é conhecido o procedimento de retirada de pequenos fragmentos de um tecido para estudo. Esse procedimento varia dependendo do local onde será realizado, podendo ser invasivo ou não. Algumas biópsias são indicadas para o diagnóstico de tumores de localização profunda, tais como: coluna vertebral, ossos, fígado, pulmão, etc. Nestes casos é utilizada uma agulha com características próprias de acordo com o tecido a ser extraído para exame [MELLO, 2001].

\subsubsection{Transplante de Medula Óssea}

O transplante de medula óssea é um procedimento médico relativamente novo utilizado para tratar doenças até então consideradas incuráveis. 0 primeiro transplante efetuado com sucesso ocorreu em 1968 e desde então este procedimento vem sendo utilizado em pacientes com leucemia, anemia aplástica (aplastic anemia), linfomas, múltiplos mielomas, distúrbios do sistema imunológico e alguns tipos de tumores sólidos como câncer de mama ou de ovário [STEWART, 1992]. O procedimento de transplante é composto por duas etapas: coleta da medula óssea a partir de um doador ou do próprio paciente, seguida de um processo semelhante à uma transfusão sangüínea [PIZZO e 
POPLACK, 1997]. A coleta da medula é geralmente feita na crista ilíaca (região da bacia), sendo que em adultos pode ser feita também a partir do osso esterno (região do tórax). A Figura 11 indica a localização dos ossos ilíaco e esterno.

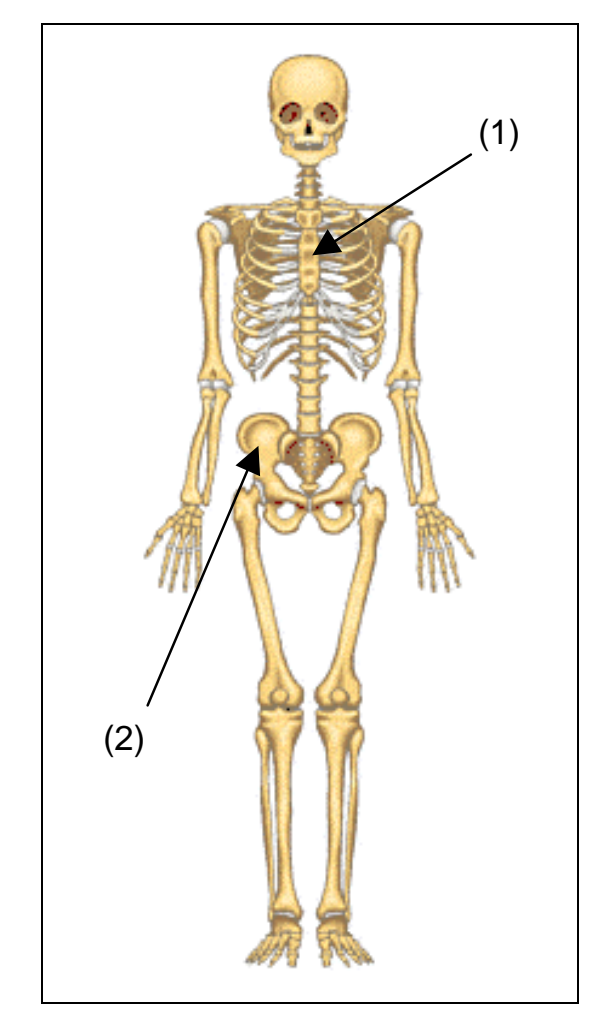

Figura 11: Localização dos pontos de coleta de medula óssea em adultos: (1) osso esterno e (2) osso ilíaco.

\subsubsection{Transplante de Fígado}

Um transplante de fígado é indicado quando uma doença evolui para a insuficiência hepática e pode ser feito a partir de órgãos de doadores clinicamente mortos ou de um doador vivo. No caso de doadores vivos, o transplante é feito retirando-se apenas parte do fígado do doador. A cirurgia do paciente receptor para recebimento do novo fígado é bastante complexa, com duração variável entre 6 e 20 horas, dependendo das condições do paciente. Em qualquer caso, o ato cirúrgico é dividido em 3 partes: retirada do fígado 
doente, implante do novo órgão, com a ligação dos dutos biliares e veias, e finalmente a ligação das artérias envolvidas [MAKSOUD, 1998].

\subsubsection{Práticas Correntes de Treinamento}

0 treinamento médico de procedimentos invasivos é tradicionalmente realizado com modelos plásticos, cadáveres ou cobaias, como porquinhos-da-índia, e posterior observação do procedimento real sendo executado por médicos experientes. No entanto, cada uma dessas formas de treinamento possui alguma inconveniência. Determinadas regiões do corpo humano podem não possuir modelos plásticos correspondentes, além do fato destes apresentarem manipulação limitada (no caso de perfurações ou cortes) e não possuírem as características físicas do tecido humano. Cadáveres, por outro lado, são difíceis de serem obtidos em boas condições para estudo, apresentam elevados custos de manutenção e em certos tipos de treinamento podem não representar as características fisiológicas e anatômicas necessárias referentes a um organismo vivo. As cobaias, por sua vez, apresentam características apenas semelhantes e não iguais as de um corpo humano e oferecem uma manipulação limitada. No caso do treinamento onde o médico aprendiz observa um especialista executando um procedimento, o primeiro não executa o procedimento por si mesmo e, portanto, não consegue interagir com o corpo do paciente e não sente as propriedades do órgão ou região manipulada.

\subsection{Requisitos Para um Sistema de Treinamento}

O uso de sistemas de RV para o treinamento de procedimentos em medicina permite oferecer plataformas de treinamento onde 0 médico iniciante pode aprender em um ambiente que simula a situação real. Uma vez que sistemas de RV têm como base a interação e a imersão em ambientes realistas, ela é capaz de oferecer uma forma de treinamento que não se limita a imitar a realidade do treinamento convencional, mas que pode reproduzir o procedimento real 
oferecendo treinamento. Para isso, devem ser utilizados objetos tridimensionais que reproduzam a área ou o objeto do estudo (ou até mesmo o ambiente do treinamento) além de dispositivos de interação capazes de receber e enviar informações relativas à manipulação esses objetos. Uma vez que exista manipulação tridimensional, é recomendável que o mesmo aconteça com a apresentação e visualização das imagens.

Outros requisitos desejáveis estão relacionados à adequação do dispositivo de interação, ou seja, este deve ter uma empunhadura e manejo o mais próximo possível dos instrumentos utilizados na realidade. 0 posicionamento do usuário diante do sistema durante a execução do treinamento também deve ser levado em conta. Assim como estas, outras particularidades podem surgir de acordo com o procedimento médico abordado para a construção de um sistema de treinamento baseado em RV. A adequação desses fatores pode alterar de forma significativa o grau de realismo do sistema.

\subsection{Proposta de um Sistema de Simulação}

É de interesse deste trabalho oferecer uma opção de treinamento realista, cujos custos sejam acessíveis, permitindo sua implantação e disseminação no ambiente hospitalar ou de ensino para fins didáticos. Propôs-se neste trabalho a pesquisa e desenvolvimento de um simulador que demonstre a potencialidade da realidade virtual aplicada em sistemas de treinamento médico em oncologia pediátrica. Essa nova forma de treinamento utilizando RV deve permitir que 0 médico tenha as impressões sensoriais semelhantes às do procedimento real, preparando-o técnica e psicologicamente para enfrentar uma situação real.

O desenvolvimento de um simulador baseado em RV para o treinamento de biópsia, transplante de medula óssea ou transplante de fígado requer o uso de um dispositivo háptico que permita ao usuário sentir as forças e resistências envolvidas na manipulação dos tecidos. No entanto, sabe-se que a tecnologia utilizando interfaces hápticas ainda está em desenvolvimento e portanto 
apresenta uma série de limitações em termos de plataforma de execução, ambiente operacional e custos. Por outro lado, sistemas com imagens realistas, estereoscopia, interação háptica e deformação de objetos, geralmente requerem o uso de máquinas com processamento paralelo e alto desempenho gráfico.

Para uma aplicação envolvendo biópsia seria necessária a apresentação de todo o corpo humano, com a possibilidade de biópsias invasivas e não-invasivas e deformação de tecidos em diferentes regiões. Levando-se em conta apenas a quantidade de pontos e polígonos envolvidos no processo de visualização de toda a anatomia, o sistema não seria viável economicamente devido às necessidades da plataforma computacional. Para o transplante de fígado o grau de realismo necessário e a deformação, por si sós, já requerem o uso de equipamentos de alto desempenho e custo. 0 transplante de medula óssea, por sua vez, aborda uma região específica do corpo quando realizada em crianças e é um procedimento utilizado em diferentes tipos de tratamento pelo DP-FMUSP, conforme citado na seção 3.3.2. Por essa razão, optou-se por conduzir a pesquisa tendo como foco o transplante de medula óssea, descrito com mais detalhes a seguir.

\subsubsection{O Transplante de Medula Óssea}

O transplante de medula óssea é um procedimento médico utilizado para tratar doenças como leucemia, anemia aplástica, linfomas, múltiplos mielomas, distúrbios do sistema imunológico e alguns tipos de tumores sólidos como câncer de mama ou de ovário [STEWART, 1992]. O transplante de medula óssea também é indicado para pacientes que serão submetidos a sessões de quimioterapia ou radioterapia, uma vez que estes tratamentos destroem não só células defeituosas, mas também células saudáveis. Assim, após as sessões de quimioterapia ou radioterapia o paciente receberá o transplante para fortalecer seu sistema imunológico [PIZZO e POPLACK, 1997]. 
A medula óssea é um tecido esponjoso encontrado no interior dos ossos. $\mathrm{Na}$ medula óssea dos ossos do peito, crânio, quadris, costelas e da espinha dorsal existem células-chave, que são células maduras capazes de se gerar cópias idênticas de si mesmas e que produzem as células sangüíneas do corpo. Essas células incluem: as células brancas (leucócitos) que protegem o organismo contra infecções, as células vermelhas que carregam oxigênio e removem impurezas dos órgãos e tecidos, e as plaquetas que atuam na coagulação sangüínea (Figura 12). Acredita-se que $95 \%$ da produção de células sangüíneas do corpo humano acontece na medula óssea e o restante no baço [FOX, 1996].

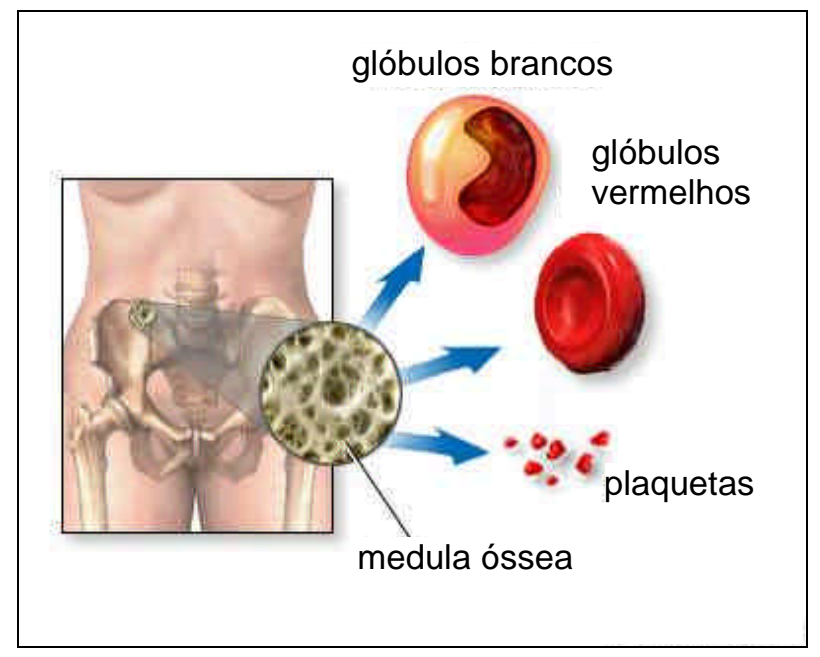

Figura 12: A medula óssea e as células sangüíneas pelas quais é responsável pela produção.

O transplante de medula óssea é composto por duas etapas principais: coleta da medula óssea a partir de um doador ou do próprio paciente, seguida de um processo semelhante à uma transfusão sangüínea [PIZZO e POPLACK, 1997]. A coleta da medula óssea é feita com contínuas aspirações do material encontrado no interior do osso, estando o paciente sob anestesia geral. No total retira-se a medula óssea em uma proporção de 10 a $20 \mathrm{ml} / \mathrm{Kg}$ em relação ao doador ou receptor, valendo o peso do menor dentre os dois [PIZZO e POPLACK, 1997]. Em um transplante de medula óssea efetuado com sucesso, a 
nova medula óssea migra para a cavidade dos grandes ossos do corpo, aloja-se e inicia a produção de células sangüíneas normais. A completa recuperação do sistema imunológico do paciente leva de seis meses a um ano [PIZZO e POPLACK, 1997].

Existem três tipos de transplante de medula óssea: 0 alógeno (Figura 13), 0 singênico e o autógeno (Figura 14), descritos a seguir.

1) Transplante Alógeno - uma pessoa cujo sangue combina geneticamente com o do paciente é o doador, geralmente um irmão ou uma irmã.

2) Transplante Singênico - semelhante ao transplante alógeno, só que neste caso o doador é um irmão gêmeo idêntico.

3) Transplante Autógeno - o paciente é o próprio doador e receberá suas células de volta após passar por tratamento. Uma grande vantagem desse tipo de transplante é que não ocorre a rejeição, a qual pacientes receptores de material de outros doadores estão sujeitos.

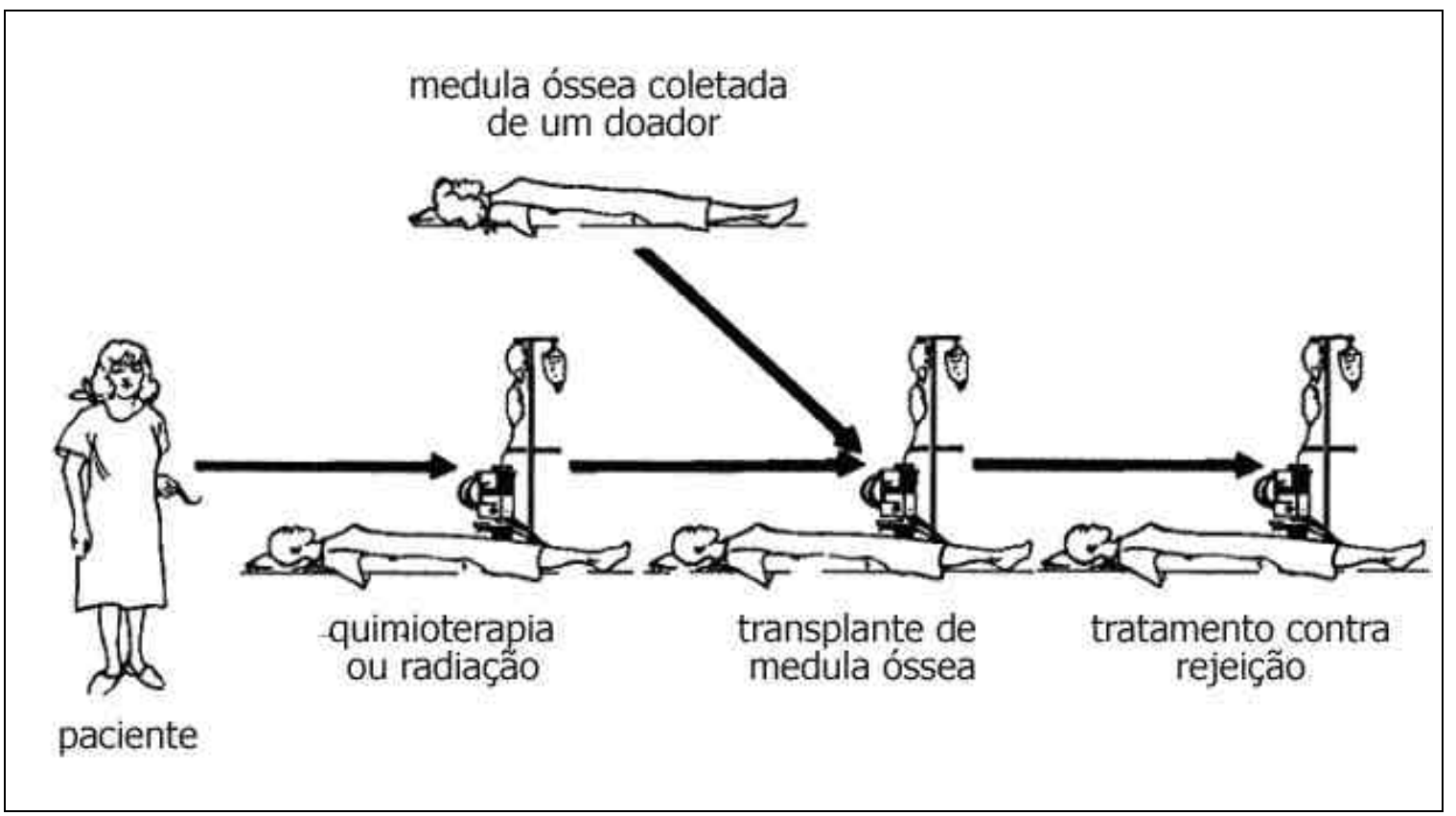

Figura 13: O transplante de medula óssea alógeno. 


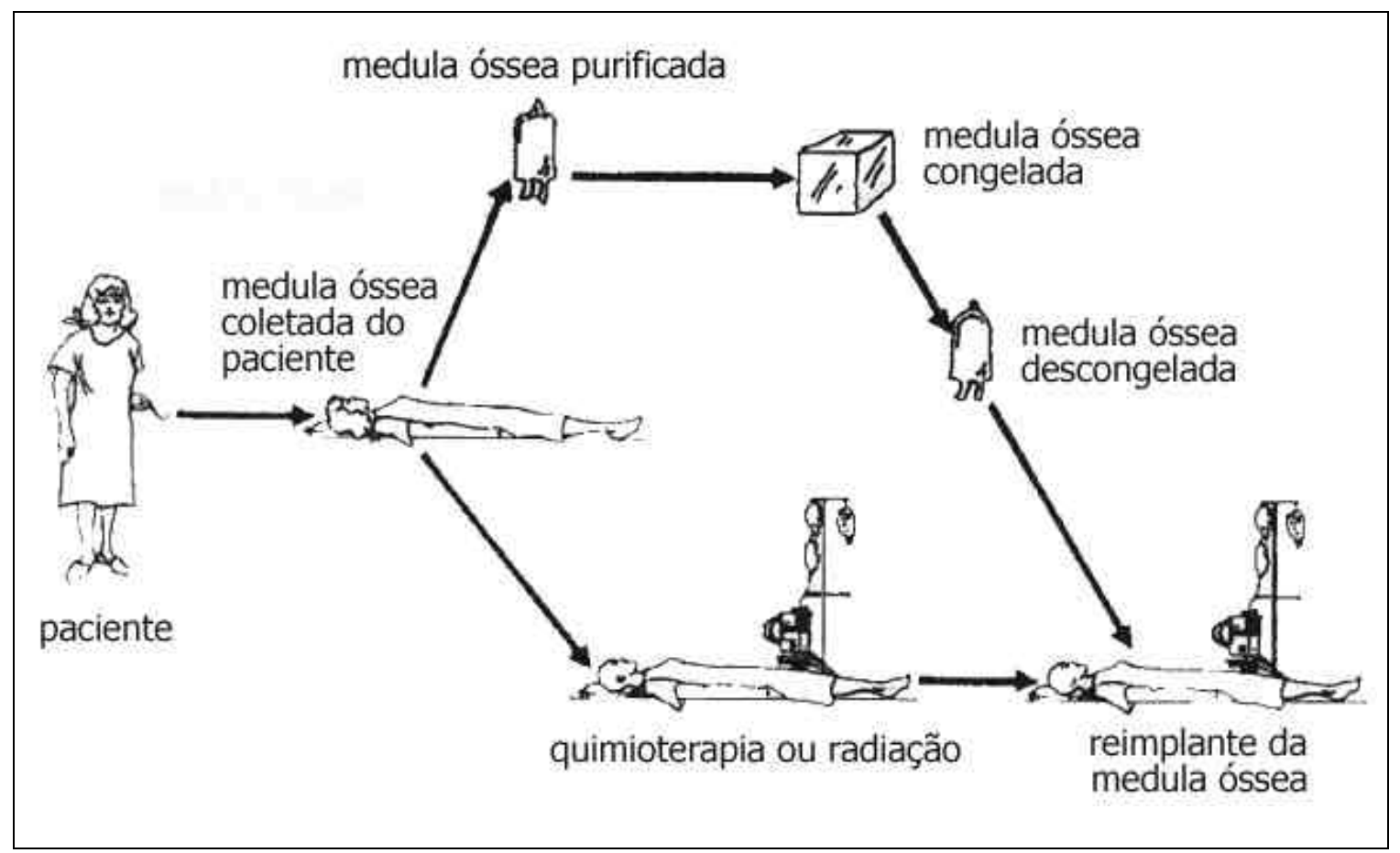

Figura 14: 0 transplante de medula óssea autógeno.

\subsubsection{Problema Abordado: A Coleta de Medula Óssea}

Segundo foi constatado em conversas com alguns médicos do DP-FMUSP, em duas etapas do transplante de medula óssea o médico interage com um paciente, seja ele doador ou receptor da medula: na coleta e no implante da medula óssea. Destas duas etapas, a coleta de medula óssea é a mais crítica pois o médico a realiza sem visualizar o interior do corpo do paciente e um erro pode causar lesões ao paciente doador. Assim, para este projeto foi selecionado como estudo de caso a coleta de medula óssea em crianças para transplante.

A coleta de medula óssea aparenta ser um procedimento bastante simples: o médico deve penetrar com uma agulha no osso da bacia do paciente e aspirar medula óssea. No entanto, a trivialidade é apenas aparente, pois existe toda uma preparação do sistema imunológico do paciente para que o procedimento possa ser executado. Além disso, o processo de coleta tende a ser mais 
doloroso em crianças devido à menor dosagem de anestesia ministrada, ocasionando dor durante e após a coleta.

A coleta da medula óssea em humanos é feita principalmente a partir do osso ilíaco, localizado na bacia, e do osso esterno, localizado no peito. Em crianças, devido à fina espessura do esterno, a coleta da medula é feita apenas na bacia devido ao fato de o osso apresentar espessura e dureza suficientes para a realização do procedimento. 0 ponto correto de coleta é a crista do osso ilíaco. A Figura 15 ilustra a região de coleta em crianças.

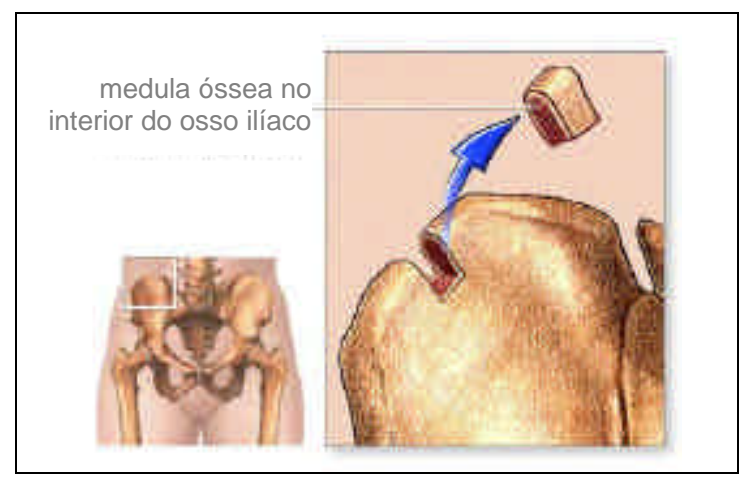

Figura 15: Região de coleta da medula óssea em crianças.

Para o processo de coleta é utilizada uma agulha de nome Illinois, com aproximadamente 2 milímetros de espessura (Figura 16). Essa agulha penetra as camadas de tecido, desde a mais externa, até o interior do osso, local de onde será extraída a medula óssea. Durante a coleta, a agulha perfura várias vezes o osso, fazendo-o sempre que a retirada de material de uma determinada região se esgota [ODONE $\mathrm{F}^{\circ}, 2001$ ].

0 procedimento completo é executado sem nenhum tipo de informação visual, ou seja, o médico deve tocar externamente a criança, determinar o local correto de inserção da agulha através do tato e então iniciar a penetração, sentindo as camadas de tecido atravessadas pela agulha, e determinar 0 momento certo de iniciar a aspiração. A agulha deve penetrar o osso, e para isso existe uma quantidade de força a ser aplicada pelo médico, que se aplicada 
em excesso pode causar dor excessiva na criança após a coleta, podendo também afetar a articulação superior da perna [ODONE $F^{\circ}, 2001$ ].

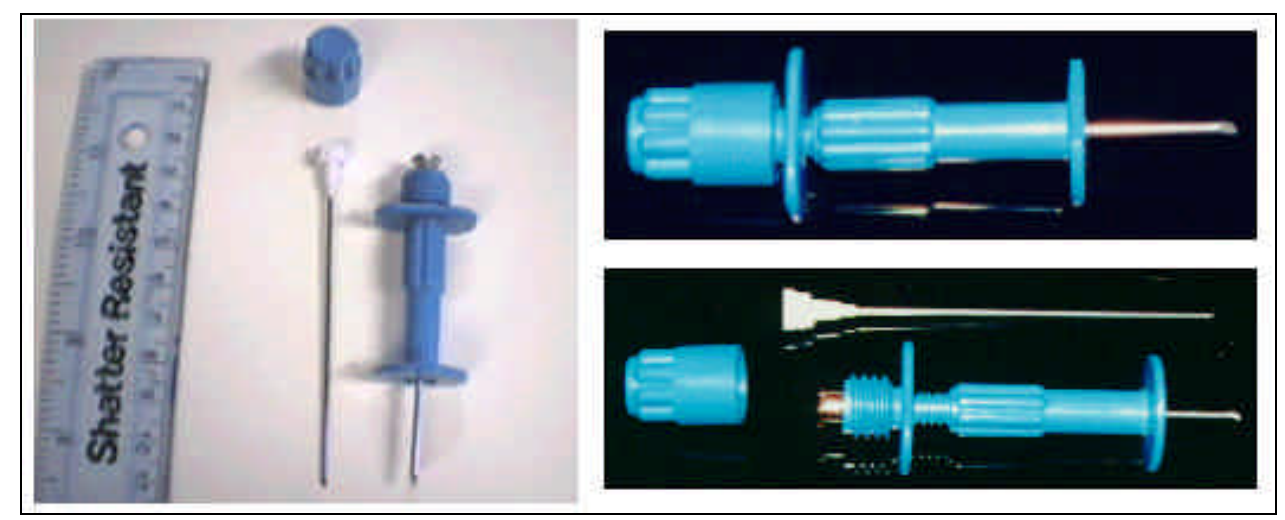

Figura 16: A agulha Illinois utilizada na coleta de medula óssea.

Apesar de aparentemente simples, a coleta de medula óssea exige destreza, pois o paciente doador atravessa um período de preparação que limita seu sistema imunológico [PIZZO e POPLACK, 1997]. Durante esse período o paciente é isolado e mantido sob monitoração constante. Além disso, como na maioria dos transplantes, existe a dificuldade em se encontrar doadores, quando isso é necessário, e o custo elevado do transplante. Esses fatores impedem que no caso de uma coleta mal sucedida o procedimento possa ser repetido em um período curto de tempo [ODONE $F^{\circ}, 2001$ ].

Atualmente o treinamento de coleta de medula óssea é realizado utilizando-se porquinhos-da-índia. A escolha desse tipo de animal deve-se ao fato destes possuírem as características anatômicas da região semelhantes às dos seres humanos. Esses animais são utilizados um número finito de vezes por estudantes que, utilizando uma agulha, procuram perceber as camadas de tecido presentes durante o processo de perfuração [MELLO, 2001]. Após essa etapa os médicos novatos observam coletas reais sendo executadas e posteriormente executam a coleta assistidos por especialistas. 


\subsubsection{A Solução Proposta}

A solução proposta como demonstração das potencialidades dos sistemas de realidade virtual em oncologia pediátrica foi o desenvolvimento de um simulador de coleta de medula óssea em crianças, etapa presente e essencial ao transplante da medula óssea. Para o desenvolvimento dessa aplicação é imprescindível o suporte da comunidade médica em todas as etapas do projeto. Com o uso do simulador, o médico deve adquirir habilidade para efetuar a coleta em crianças, além de poder aprimorar sua técnica.

Observamos que a forma de treinamento tradicional, utilizando porquinhos-daíndia, oferece condições similares à realidade da coleta, mas não iguais. Apesar das semelhanças anatômicas da região da bacia, esses animais não possuem características relativas à densidade dos tecidos iguais às de uma criança e apresentam rápida degradação dos tecidos após o seu sacrifício, conforme mostra o estudo de Holton [HOLTON, 2001].

Assim, o simulador para treinamento deve permitir ao usuário do sistema treinar todas as etapas envolvidas na coleta de medula óssea de forma realista, desde o estudo da anatomia local até a coleta da medula óssea, oferecendo estímulos sensoriais semelhantes ao procedimento real de coleta de medula óssea [MACHADO et al., 2000b][MACHADO et al., 2001a]. Pretende-se com 0 simulador:

- apresentar a região de interesse baseada na anatomia humana, com 0 objetivo de permitir o estudo interativo da região, com possibilidade de visualização e identificação das estruturas internas da região de interesse;

- permitir a palpação prévia da região do corpo onde será realizada a coleta, oferecendo a possibilidade de identificação tátil da estrutura óssea sob a pele e conseqüente localização do local correto de inserção da agulha;

- permitir a perfuração do modelo tridimensional oferecendo as sensações táteis associadas a essa ação para a percepção das estruturas trespassadas durante 
essa operação e conseqüente determinação do local correto de parada da perfuração, ou seja, quando o interior do osso é alcançado;

- oferecer treinamento médico baseado no modo de execução do procedimento real, sendo que para isso deve contar com o suporte de profissionais e especialistas no procedimento tratado.

\subsection{Conclusão}

Este capítulo apresentou a oncologia pediátrica e procedimentos invasivos cujo desenvolvimento de um simulador poderia trazer benefícios ao processo de treinamento de novos médicos. Considerações sobre esses procedimentos foram tecidas a fim de estabelecer os principais requisitos que devem ser incorporados a um simulador de treinamento voltado para tais modalidades.

Finalmente, foi apresentada uma proposta inédita para o treinamento em oncologia pediátrica, onde o procedimento de coleta de medula óssea foi abordado como foco de desenvolvimento de um simulador. Sendo este 0 primeiro simulador voltado para pediatria baseado em realidade virtual esperase oferecer com esse sistema condições de treinamento que transcendam o método de treinamento tradicional, onde cobaias são utilizadas, apresentado ao médico/usuário um sistema de treinamento que reproduza a coleta real, sob os aspectos visuais e táteis. 
4 Projeto e Implementação de um Simulador para Treinamento em Coleta de Medula Óssea 


\subsection{Introdução}

Este capítulo traz os detalhes de desenvolvimento do simulador de coleta de medula óssea. Uma descrição funcional do simulador apresenta os módulos que o compõem e que obedecem a seqüência de execução do procedimento real. Aspectos relacionados à definição dos componentes do simulador em termos de plataforma e ambiente de execução também são discutidos, ressaltando os subsistemas tátil e visual.

A implementação do simulador é descrita abordando desde a geração dos modelos tridimensionais utilizados pelo sistema e o detalhamento das rotinas de estereoscopia e atuação háptica até a apresentação do simulador integrado. Finalmente é apresentado o método utilizado para a calibragem das propriedades físicas dos objetos.

\subsection{Descrição Funcional do Simulador}

O simulador desenvolvido é um sistema de realidade virtual semi-imersivo, que possibilita ao usuário treinar todas as etapas envolvidas no procedimento de coleta de medula óssea por meio de simulação. Em termos de arquitetura do sistema, existem três módulos, responsáveis por cada etapa da simulação, e um submódulo. Os módulos e o submódulo foram definidos de acordo com sua funcionalidade e a execução destes obedece a seqüência de realização do procedimento real. Uma vez que o objetivo do simulador é oferecer treinamento, um módulo inicial para estudo da anatomia foi incorporado. Assim, os módulos que compõem o simulador são:

- Módulo de Observação da Anatomia: permite estudar a região de interesse do corpo. Ligado ao Submódulo para Observação Interna, que permite ao usuário observar o interior do corpo para visualizar algumas estruturas internas; 
- Módulo de Localização: permite ao usuário definir a região na qual a agulha será inserida;

- Módulo de Coleta: responsável pela simulação do procedimento de coleta da medula óssea, uma vez definida a posição de inserção da agulha.

A reunião desses módulos, integrados conforme mostra a Figura 17, forma o Simulador de Coleta de Medula Óssea. Todas as etapas do procedimento real são abordadas nesse sistema com uma opção adicional de visualização interna. Essa opção permite ao médico/estudante observar o que se passa dentro da região sendo manipulada. Uma vez que o propósito do simulador é treinamento, esse submódulo foi inserido para permitir observar e estudar a anatomia externa e interna da região trazendo uma maior autoconfiança ao estudante do procedimento cirúrgico.

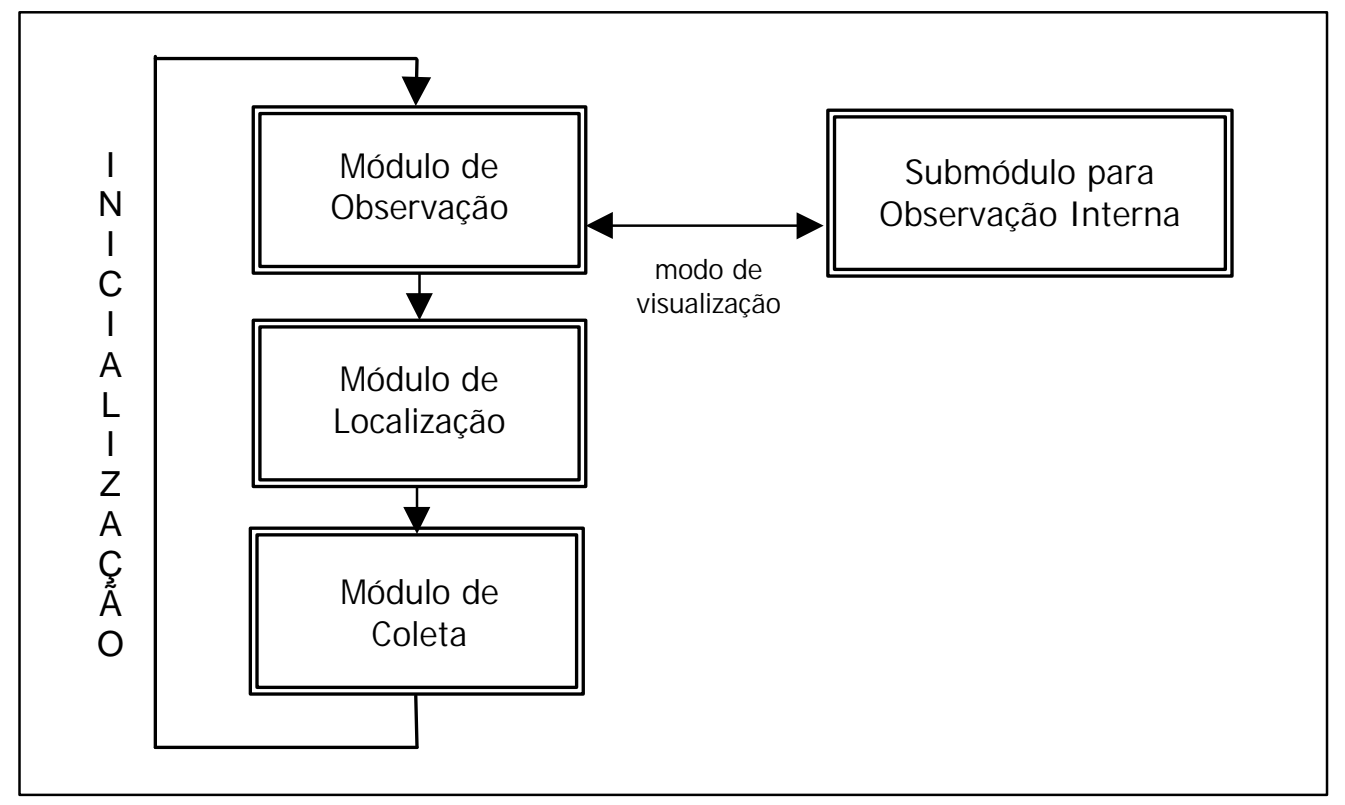

Figura 17: O Simulador de Coleta de Medula Óssea e seus módulos funcionais.

Em termos de equipamentos, os itens mais importantes relacionam-se à forma de comunicação usuário-sistema, ou seja, a interação dos médicos com o simulador deve ser natural e permitir-Ihes conforto na manipulação 
de dispositivos. Para aplicações em medicina esses itens são necessários principalmente para a visualização e o toque. No simulador optou-se pela utilização de um microcomputador convencional provido do equipamento necessário para o desempenho dos módulos de programação acima enumerados, como dispositivos que permitem a manipulação com retorno de força e a visualização tridimensional.

O simulador encontra-se também preparado para receber um Módulo de Avaliação que permitirá o monitoramento dos movimentos do usuário para a classificação da qualidade do treinamento realizado [MACHADO et al., 2000a].

\subsubsection{Módulo de Observação da Anatomia}

Uma das grandes vantagens dos sistemas de realidade virtual é a possibilidade de exploração de objetos e mundos de modo tridimensional. No caso do simulador de coleta de medula óssea, a área de interesse - a região da bacia - foi modelada e programada para ser exibida em três dimensões (com estereoscopia), permitindo a visualização em camadas semi-transparentes, onde as estruturas internas ficam visíveis. A exploração do modelo é possível com movimentos de translação e rotação. Este módulo é conectado ao submódulo para observação visualização interna.

\subsubsection{Submódulo para Observação Interna}

Durante a realização do procedimento de coleta de medula óssea real não é possível a visualização das estruturas internas do corpo. Essa característica é oferecida pelo simulador desenvolvido, permitindo ao usuário observar algumas estruturas internas na região de interesse. Uma vez que o procedimento é realizado às cegas, ou seja, sem informação visual, o usuário deverá selecionar essa opção em um menu. 
O objetivo do Submódulo para Observação Interna é permitir a identificação das estruturas internas, facilitando discussões em grupo e explicações, sem condicionar o usuário a esta facilidade, não possível no procedimento real.

\subsubsection{Módulo de Localização}

O Módulo de Localização permite ao usuário a observação e a determinação do local de inserção da agulha virtual. A tarefa é realizada da mesma forma que no procedimento real, onde o médico toca a criança para localizar o ponto adequado de penetração da agulha.

Para essa tarefa, o simulador permite a visualização do corpo da criança na região de interesse. Além disso, a necessidade de toque para identificação do local é simulada com o uso de um dispositivo háptico. A visualização tridimensional faz-se necessária neste ponto, devido ao uso do dispositivo háptico: uma vez que o usuário manipula uma ferramenta que se movimenta com seis graus de liberdade (6DOF), é importante que a visualização seja compatível, permitindo a localização no espaço visualizado do posicionamento do dispositivo.

\subsubsection{Módulo de Coleta}

O Módulo de Coleta permite a simulação e treinamento da coleta de medula óssea em um modelo tridimensional da região pélvica. Nesse módulo, o modelo tridimensional utilizado é composto pelas camadas internas de tecido da região. Cada uma dessas camadas possui propriedades físicas diferentes que são sentidas pelo médico no momento de penetração com a agulha. Essas camadas são: epiderme, derme, subcutâneo, periósteo, osso compacto e medula óssea, conforme mostra a Figura 18.

As características das camadas, segundo uma descrição subjetiva obtida de especialistas em coleta de medula óssea são: 
Epiderme: aproximadamente $2 \mathrm{~mm}$ de espessura, elástica e escorregadia;

Derme: aproximadamente $7 \mathrm{~mm}$ de espessura, elástica;

Subcutâneo: aproximadamente $4 \mathrm{~mm}$ de espessura, macio e sem resistência;

Periósteo: aproximadamente $2 \mathrm{~mm}$ de espessura, resistente, escorregadio, lubrificado e liso;

Osso compacto: aproximadamente $5 \mathrm{~mm}$ de espessura, duro e resistente;

Medula óssea: aproximadamente $10 \mathrm{~mm}$ de espessura, macia e sem resistência.

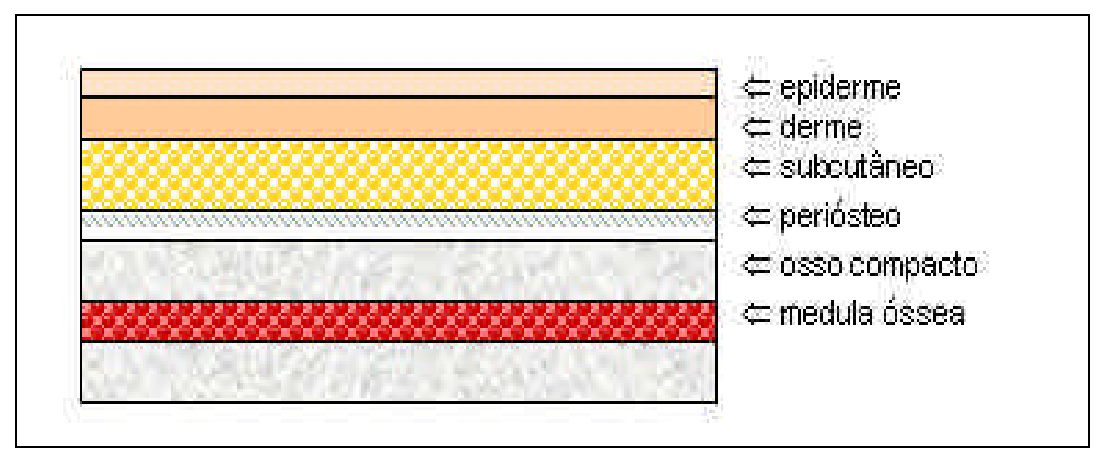

Figura 18: Camadas de tecido da região pélvica.

Pela manipulação de um dispositivo háptico o usuário do simulador deve sentir a ultrapassagem das camadas de tecido e determinar o momento correto de iniciar a coleta da medula, ou seja, identificar quando a medula óssea é alcançada.

\subsection{Definição dos Componentes do Simulador}

O Simulador de Coleta de Medula Óssea é um sistema composto por dispositivos físicos e programas de computador. Para melhor entendimento do leitor, será chamado de plataforma de execução o conjunto de 
dispositivos físicos do simulador, como placas, dispositivos de interação e dispositivos de visualização. 0 conjunto composto pelas linguagens de programação, bibliotecas e sistema operacional será chamado de ambiente de execução e programação.

Uma vez que sistemas de realidade virtual podem ser desenvolvidos para diferentes finalidades, a escolha da plataforma e ambiente de execução dependerá dessa finalidade. Na definição dos componentes do simulador de coleta de medula óssea o ponto principal e que demandou maior atenção foi 0 fato do procedimento real ser realizado sem nenhum tipo de informação visual do interior do corpo do paciente, dependendo apenas do toque do médico no corpo do paciente. Esse toque permite determinar a região adequada para a inserção da agulha e identificar o local onde se encontra a medula óssea. Essa característica do procedimento de coleta de medula óssea real fez com que o simulador necessitasse de algum tipo de dispositivo que permitisse ao usuário tocar e perceber as estruturas ósseas sob a pele do paciente. Outra característica desejada foi a possibilidade de oferecer algum tipo de estudo prévio da região do corpo a ser manipulada ampliando e realçando as possibilidades do estudo real baseado em imagens 2D ou em modelos plásticos.

A seleção dos equipamentos de visualização e háptico afetou a escolha do sistema operacional e das linguagens de programação [MACHADO et al., 2001c].

\subsubsection{Plataforma de Execução}

A plataforma de execução do simulador engloba os dispositivos físicos do simulador, como placas, dispositivos de interação e dispositivos de visualização. Para a escolha dessa plataforma levou-se em conta que 0 simulador deve ser utilizado por médicos e que deve ter custos que permitam a sua implementação no ambiente do hospital. Assim, optou-se 
pelo desenvolvimento de um simulador baseado em um computador do tipo PC uma vez que, com as opções de placas aceleradoras gráficas (placas de vídeo) e processadores encontrados atualmente no mercado já é possível obter um excelente desempenho de aplicações gráficas nesse tipo de equipamento.

Devido à complexidade geométrica da região do corpo utilizada na simulação, o microcomputador foi equipado com 256Mb de memória RAM. A conexão dos equipamentos utilizados pode ser observada na Figura 19. A Figura 20 mostra a plataforma de execução real.

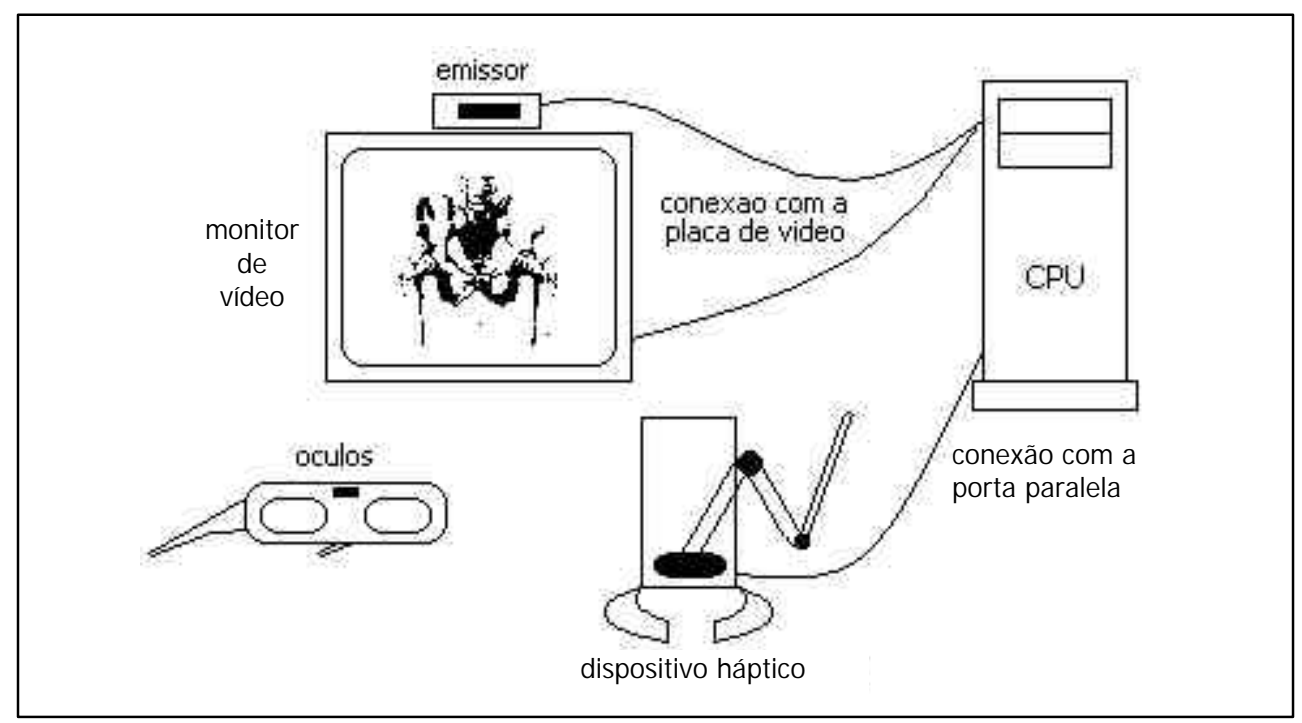

Figura 19: Esquema da conexão física dos dispositivos ao computador: a imagem do monitor é sincronizada com a obturação das lentes dos óculos por intermédio de um emissor ligado à placa de vídeo; o dispositivo háptico é conectado diretamente à porta paralela do computador.

Em termos de interação e imersão, a plataforma de execução pode ser dividida em dois subsistemas: subsistema tátil, responsável pela interação com manipulação háptica, e subsistema visual, responsável pela visualização. 


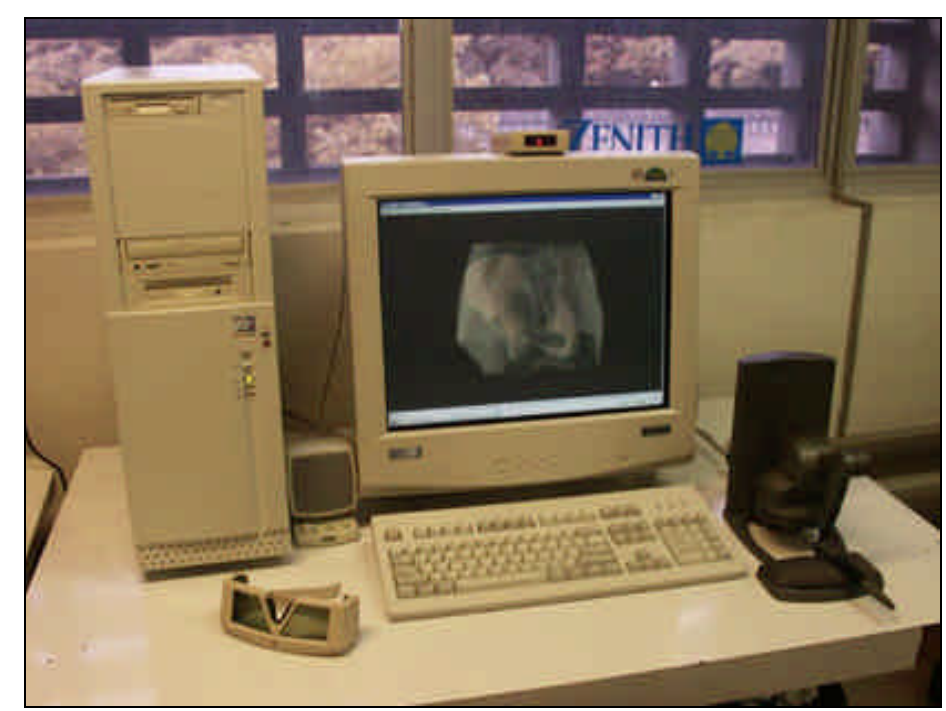

Figura 20: Plataforma de execução do simulador.

\subsubsection{Subsistema Tátil}

Para a manipulação, foram avaliados alguns dispositivos hápticos encontrados comercialmente, como o Laparoscopic Impulse Engine [IMMERSION, 2002a], a luva CyberGrasp [IMMERSION, 2002b], o Force Dimension [DIMENSION, 2002] e o Phantom [SENSABLE, 2002]. Dentre eles, o Phantom Desktop [MASSIE e SALISBURY, 1994] apresentou as características mais adequadas ao problema além do fato de sua empunhadura assemelhar-se à de uma agulha real, o que poderia proporcionar uma manipulação, e conseqüentemente uma simulação, mais realista. 0 equipamento consiste em um de braço mecânico articulado que permite movimentos com 6 graus de liberdade num espaço limitado $(x, y, z$ e rotações) e oferece retorno de força em 3 graus [MASSIE e SALISBURY, 1994]. Sua conexão ao computador é feita diretamente pela porta paralela do computador. Uma imagem do dispositivo pode ser vista na Figura 21 e suas especificações técnicas na Tabela 1. 


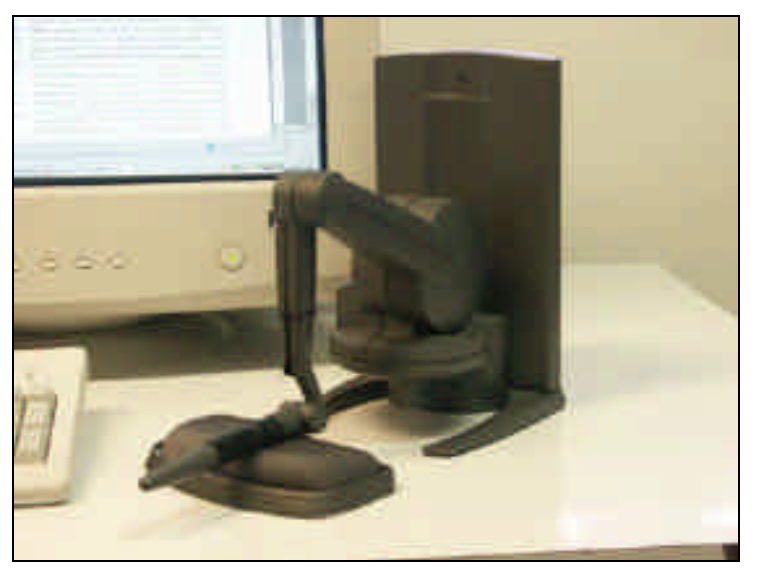

Figura 21: 0 dispositivo háptico Phantom Desktop.

Uma avaliação prévia do dispositivo háptico escolhido foi feita por três médicos que 0 consideraram bastante adequado à simulação do treinamento proposto para coleta de medula óssea. A facilidade de uso, a ausência da necessidade de vestir 0 equipamento e o fato de a sua empunhadura assemelhar-se à da agulha real, foram pontos citados como benéficos pelos médicos.

Tabela 1: Especificações técnicas do Phantom Desktop.

\begin{tabular}{|l|l|}
\hline Resolução & $0,02 \mathrm{~mm}$ \\
\hline Área de trabalho & $16 \mathrm{~cm} \times 13 \mathrm{~cm} \times 13 \mathrm{~cm}(x, y, z)$ \\
\hline Força de pico & $6,4 \mathrm{~N}$ \\
\hline Força contínua & $1,7 \mathrm{~N}$ \\
\hline Retorno de força & 3 graus de liberdade $(x, y, z)$ \\
\hline Sensor de posição & $\begin{array}{l}6 \text { graus de liberdade }(x, y, z \text { e } \\
\text { rotações })\end{array}$ \\
\hline
\end{tabular}




\subsubsection{Subsistema Visual}

Uma vez que a manipulação com o dispositivo háptico seria feita no espaço tridimensional, havia a necessidade de a visualização permitir observar 0 ambiente e os seus objetos também no espaço tridimensional. Para isso foram analisadas plataformas de visualização, dentre as quais se destacaram os monitores auto-estereoscópicos, os monitores convencionais em conjunto com óculos obturadores e os HMDs. Os HMDs foram a primeira opção descartada pois não permitiriam que mais pessoas compartilhassem a visualização do treinamento, além de precisarem ser vestidos e isolarem a visão do usuário do mundo real, onde estaria o dispositivo háptico. Os monitores auto-estereoscópicos, por sua vez, apresentaram um custo muito elevado e, segundo estudos demonstraram, produzem um desempenho semelhante ao conjunto monitor convencional com óculos obturadores [KAUFMANN et al., 2000].

Dessa forma, o sistema de exibição escolhido para a visualização estereoscópica é constituído por um monitor de vídeo e óculos obturadores. Como vantagens esse sistema apresenta a possibilidade de visualização 3D por múltiplos usuários, o não isolamento do usuário no mundo virtual e a possibilidade de uso de óculos corretivos sob os óculos obturadores. Quanto ao uso de dispositivos de detecção de movimentação, estes não foram necessários neste projeto, uma vez que existe uma única região de interesse no corpo para a execução da simulação e pelo fato de os únicos movimentos realizados pelo usuário serem reconhecidos pelo dispositivo de háptico.

No subsistema visual, os óculos obturadores e o monitor trabalham em conjunto com um emissor infravermelho conectado à placa de vídeo, responsável pela sincronização das imagens do monitor com a obturação das lentes dos óculos. 0 monitor de vídeo apresenta uma taxa de atualização que é dividida ao meio no momento da exibição estereoscópica. 
Para a utilização deste sistema de visualização, a taxa de atualização ideal é de 50 quadros por segundo para cada olho, ou seja, o monitor deverá trabalhar com pelo menos $100 \mathrm{~Hz}$. As imagens no monitor são alternadas ao mesmo tempo em que uma das lentes dos óculos é obstruída. A velocidade da alternância é rápida e não perceptível ao usuário. A Figura 22 mostra os óculos para visualização estereoscópica utilizados neste projeto.

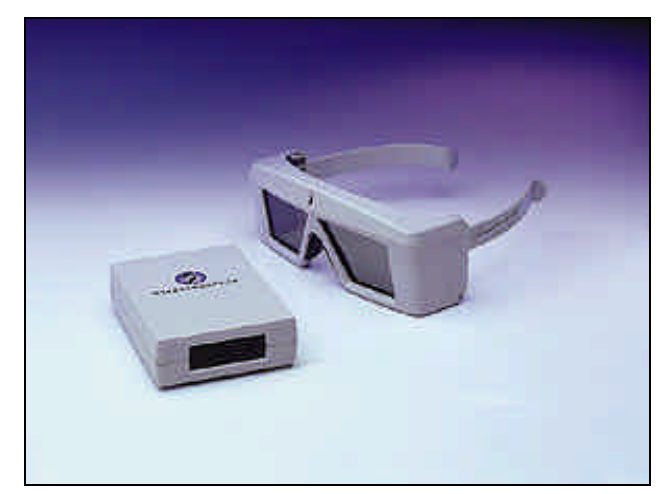

Figura 22: Conjunto composto por óculos e emissor infravermelho para visualização estereoscópica.

A placa de vídeo utilizada foi escolhida a partir de placas disponíveis no mercado que ofereciam suporte a visualização estereoscópica, disponibilizando quatro bancos de mémória intermediária de vídeo (buffers). Estes quatro bancos de memória permitem que as imagens relativas às vistas esquerda e direita do par estereoscópico gerado pelo sistema sejam armazenadas e alternadas com as imagens de primeiro plano.

\subsubsection{Ambiente de Execução e Programação}

0 ambiente de execução e programação constitui-se do sistema operacional, linguagens de programação e bibliotecas de comandos utilizados para o desenvolvimento e execução final do simulador. A escolha desse ambiente baseou-se na compatibilidade com a plataforma de 
execução adotada e no tipo de usuário final do simulador. Além disso, existiu a preocupação de utilizar-se uma plataforma cujo custo viabilizasse a implantação do sistema. No caso do dispositivo háptico, o equipamento oferecia suporte para sua utilização nos sistemas operacionais Windows NT e IRIX. Quanto ao usuário final, médicos e estudantes de medicina, o nível de conhecimento em sistemas de computadores não é avançado e portanto havia a necessidade de um ambiente de fácil assimilação e manuseio. Assim, dentre os sistemas operacionais analisados, o Windows NT foi 0 único que satisfez os requisitos desejados.

Como linguagem de programação foi adotado o $\mathrm{C}++$ para Windows e $\mathrm{O}$ conjunto de bibliotecas GHOST (General Haptic Open Software Toolkit) [GHOST, 2000], utilizado para a programação do dispositivo háptico. Além de ambos serem compatíveis, também permitiram o uso da linguagem de interface gráfica OpenGL, essencial na geração das rotinas de visualização em estéreo.

O ambiente desenvolvido apresenta sistemas de menus com opções de ativação dos dispositivos de visualização e interação bem como ajustes da paralaxe para a estereoscopia visual. Também foi programada uma barra de exibição disponível na parte inferior da janela para apresentar o módulo e opções ativas, posição espacial do dispositivo háptico e os ajustes da paralaxe visual.

\subsection{I mplementação}

O simulador é composto por três módulos funcionais responsáveis por cada uma das três etapas que compõem o treinamento real de coleta de medula óssea, conforme descrito na seção 4.2. Este módulos comunicam-se com um submódulo de visualização interna, que apresenta os modelos com semi-transparência. Conectados ao sistema como dispositivos de entrada e saída de dados, encontram-se um dispositivo háptico, teclado, mouse e um 
monitor de alta freqüência (superior a $100 \mathrm{~Hz}$ de varredura). Os comandos do usuário são realizados com o uso do teclado e do mouse, para a seleção de comandos, e do dispositivo háptico, que alimenta o sistema com a posição espacial e velocidades da manipulação durante a simulação das etapas do procedimento de coleta de medula óssea. O sistema exibe os resultados com a alteração das imagens tridimensionais e com o retorno de forças e tátil resultantes da manipulação. Os módulos foram desenvolvidos para trabalharem em uma seqüência semelhante a do aprendizado, apresentando os módulos em uma seqüência obrigatória, de acordo com os passos adotados na execução do procedimento real.

Das rotinas pertencentes ao sistema, duas têm principal importância no processo da simulação. São elas: visualização (seção 4.4.2) e atuação háptica (seção 4.4.3). Estas rotinas são responsáveis por toda parte de comunicação entre o usuário e o simulador e trabalham em função de modelos tridimensionais. A rotina de visualização processa o par estereoscópico e apresenta-0, sendo que esse par contém as três camadas do modelo da região de interesse e o cursor do dispositivo háptico nos módulos em que ele está presente. Já a rotina de atuação háptica monitora os movimentos do dispositivo háptico e verifica possíveis colisões no mundo tridimensional virtual, calculando as forças de reação a serem exibidas pelo dispositivo.

No total, existem dois mundos e modelos específicos para cada um deles: um mundo visual e um mundo tátil. Ambos são compostos por modelos tridimensionais e um cursor, mas a principal diferença reside no fato de um ser perceptível visualmente e outro apenas pelo toque [MACHADO e ZUFFO, 2002].

As rotinas de visualização e atuação háptica são totalmente independentes e trabalham em paralelo. Elas comunicam-se apenas no momento de transferência dos dados de posição espacial do dispositivo háptico. Essa comunicação permite à rotina de visualização exibir visualmente a posição 
do dispositivo háptico. A Figura 23 mostra as rotinas de visualização e atuação háptica e a comunicação destas com os dispositivos de entrada e saída.

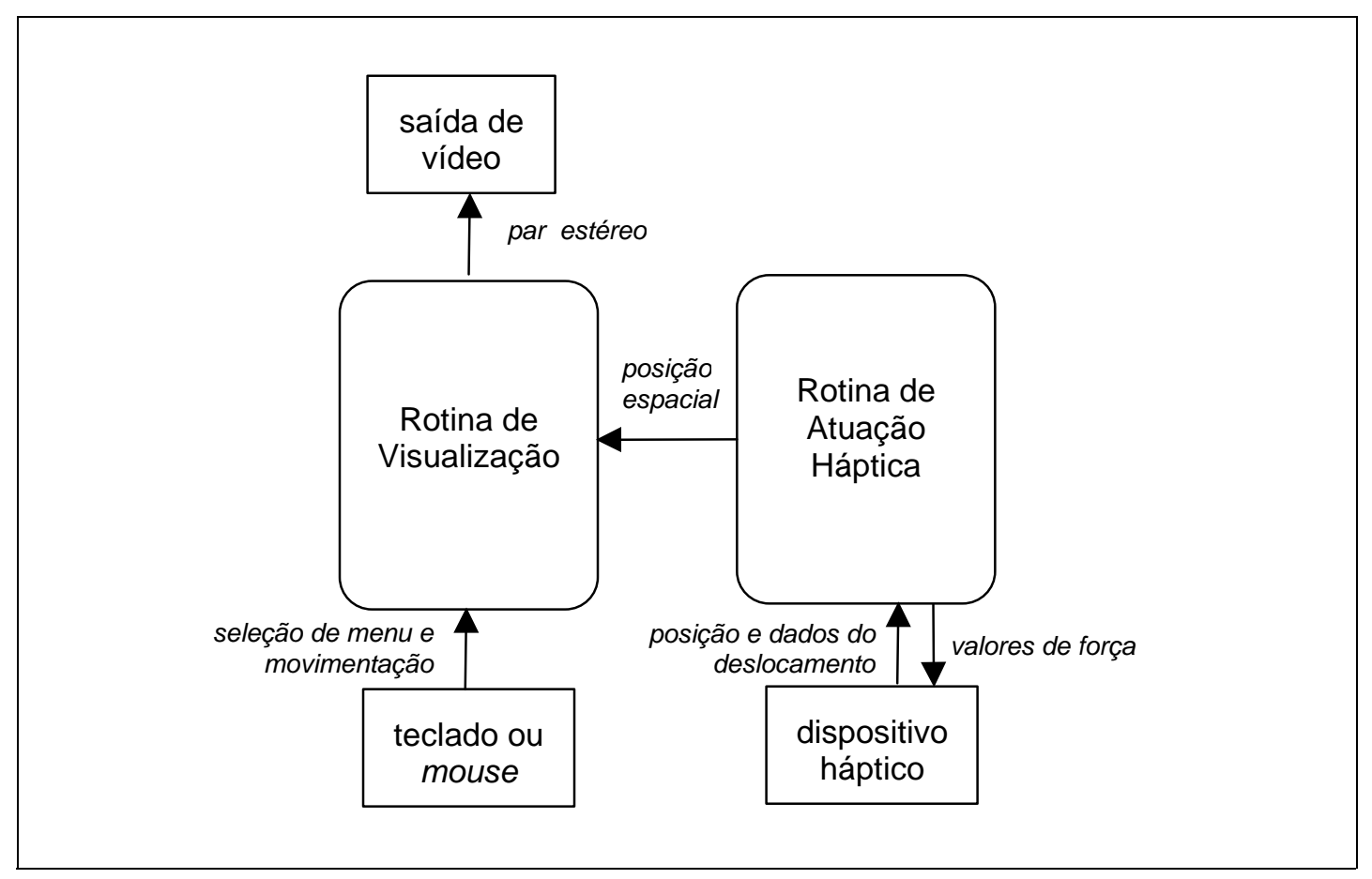

Figura 23: As rotinas de visualização e atuação háptica e sua comunicação com os dispositivos de entrada e saída.

\subsubsection{Geração dos Modelos Visuais e Táteis}

Conforme descrição feita por dois médicos especialistas, a região da bacia de onde é extraída a medula óssea é formada por seis camadas principais que apresentam características táteis e visuais diferentes entre si. Essas características foram utilizadas para a geração dos modelos utilizados no simulador visando oferecer realismo visual e tátil quando integrados ao sistema.

Como ponto de partida para a geração dos modelos foram utilizados dois modelos tridimensionais. Os modelos apresentam respectivamente a estrutura externa (pele) e óssea de um corpo humano completo (Figura 24) 
e serviram como base para a criação das seis camadas utilizadas nas rotinas de visualização e de manipulação tátil do simulador, conforme descrito ainda nesta seção.

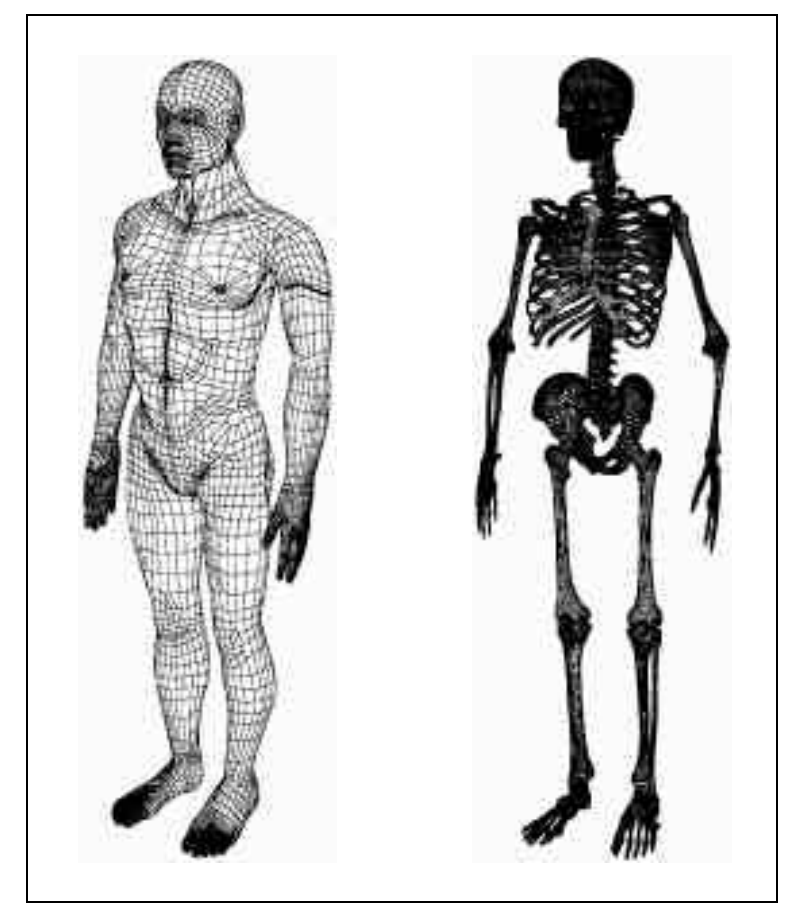

Figura 24: Modelos poligonais originais.

Pelo fato de a coleta de medula óssea em crianças ser realizada apenas no osso ilíaco, localizado na bacia, os dois modelos originais foram recortados e apenas a região de interesse foi mantida. Esse recorte foi feito utilizandose os pacotes de modelagem tridimensional Maya $^{\text {TM }}$ [ALIAS, 2003] e Softimage $^{T M}$ [SOFTIMAGE, 2003]. Um terceiro modelo, representando a medula óssea da região de interesse, foi gerado com o uso de ferramentas de erosão e suavização a partir do modelo do osso.

Ao todo foram criados, simplificados (quanto ao número de polígonos) e utilizados no simulador três modelos básicos para a representação das camadas de tecido humanas. Assim, as camadas da derme, epiderme e subcutâneo foram simplificadas e reunidas em um único modelo. 0 mesmo aconteceu com as camadas do periósteo e osso compacto, que formam a 
camada óssea. Uma terceira camada, utilizada para representar a medula óssea, foi gerada a partir do modelo ósseo da bacia.

Para as rotinas de simulação tátil, foi feita uma simplificação nos modelos reduzindo o número de pontos e polígonos. Essa redução, que não afetou a parte visual, resultou em um ganho significativo de desempenho do simulador que utiliza simultaneamente 6 modelos, três deles visuais e outros três táteis. Então, para cada uma das rotinas de visualização e de simulação tátil, foi realizada uma simplificação quanto ao número de camadas, descrita em 4.2.3:

Pele: camada externa composta por: derme + epiderme + subcutâneo;

Osso: camada intermediária composta por: periósteo + osso compacto;

Medula: camada interna representando a medula óssea.

Os modelos finais utilizados no sistema, e salvos no formato VRML (contém a descrição dos pontos e polígonos), podem ser vistos na Figura 25.

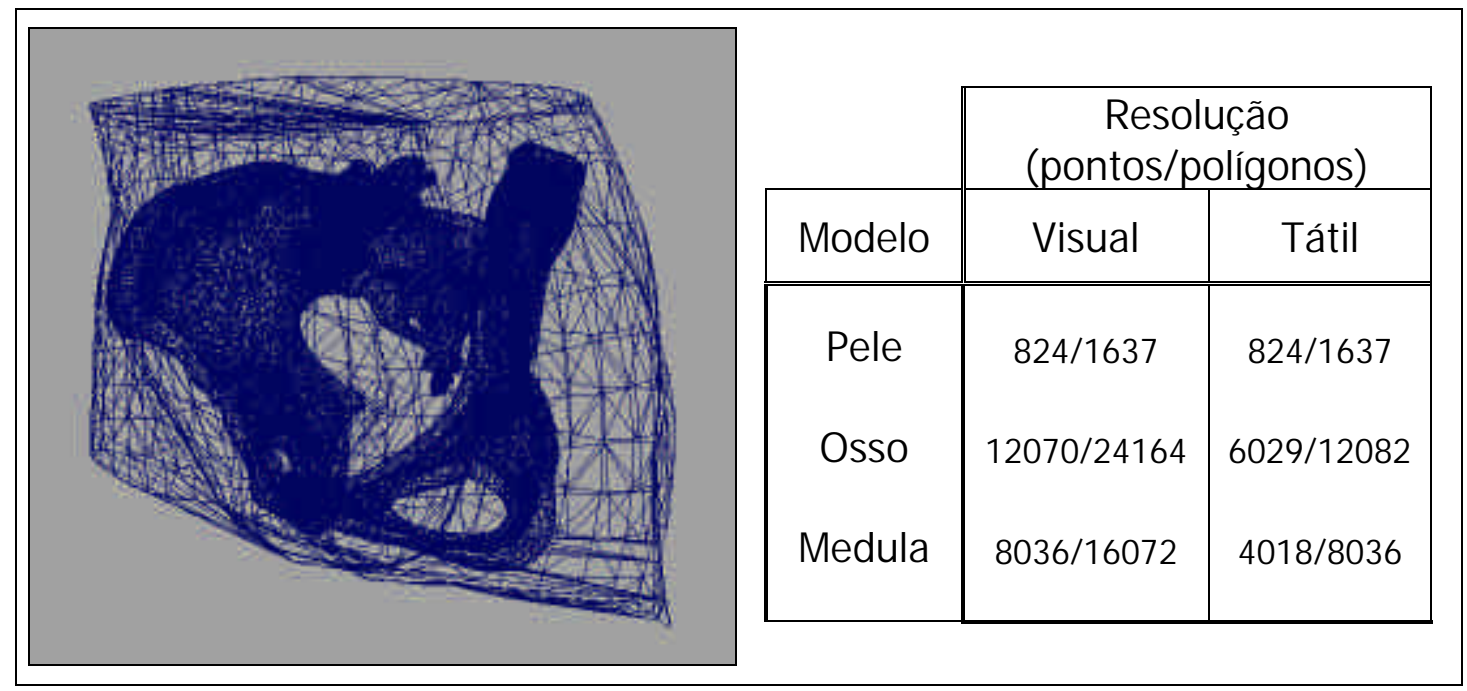

Figura 25: Conjunto dos modelos gerados e utilizados no simulador de coleta de medula óssea com a respectiva resolução. 
Além desses modelos, após um teste do sistema, descrito em 5.4.1, foram criados outros dois modelos táteis para a simulação do toque do osso sob a pele. Esses dois modelos foram gerados a partir de esferas recortadas e possuem a forma de uma calota. Posicionados na região da crista ilíaca esquerda e direita possuem a função de apresentar uma diferenciação no toque na região das cristas ilíacas durante a execução do Módulo de Localização. A Figura 26 apresenta a forma e resolução das calotas utilizadas.

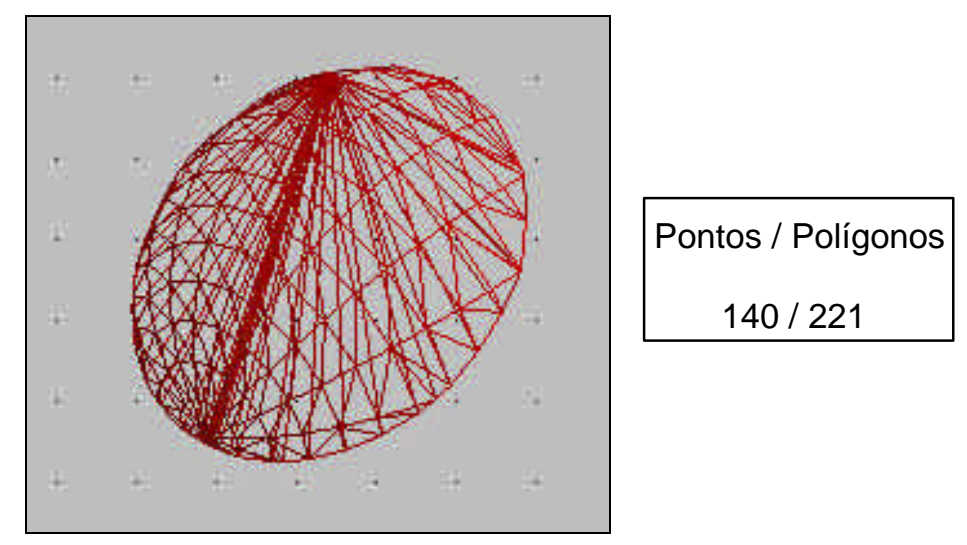

Figura 26: Formato e definição das calotas utilizada para a simulação do toque do osso sob a pele na região das cristas ilíacas.

Quanto ao dispositivo háptico, buscou-se uma forma de representação deste para que a sua indicação fosse mais significativa que um simples ponto no espaço. Para isso, foram adquiridas, a partir de modelos reais, as texturas de um dedo e uma agulha real, as quais foram utilizadas nessa representação. Projetadas sobre planos em formato de cruz elas ofereceram um maior realismo à manipulação do dispositivo (Figura 27). 


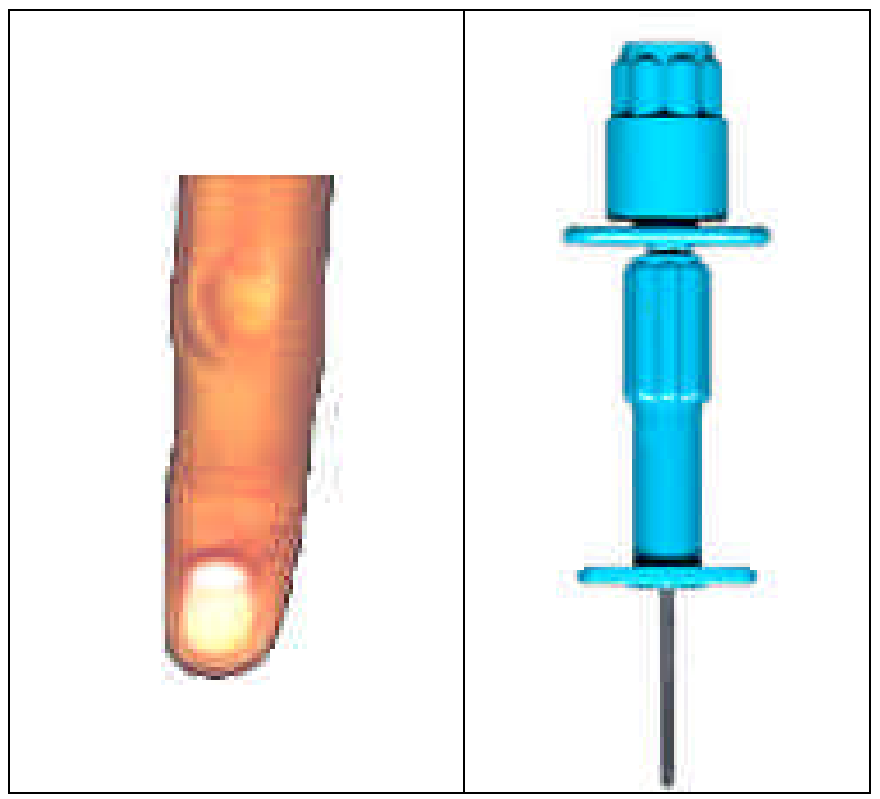

Figura 27: Imagens utilizadas para a representação visual do dispositivo háptico

\subsubsection{Rotinas de Estereoscopia}

A criação de pares estereoscópicos para sistemas computacionais pode ser feita utilizando-se projeção perspectiva ou projeção paralela. No caso de sistemas de realidade virtual, a projeção perspectiva é a mais indicada para a geração dos pares estereoscópicos, pois é mais aderente ao sistema visual humano, no qual objetos distantes do observador tendem a parecer menores que objetos próximos [MACHADO, 1997].

Assim, a implementação para obtenção das imagens do par estereoscópico foi feita utilizando-se projeção off-axis junto com uma transformação de projeção perspectiva (ver 2.3.1).

Na definição da rotina de exibição, cria-se um volume de projeção, dentro do qual os modelos tridimensionais são inseridos. Planos de projeção são então determinados de acordo com a visão necessária: esquerda ou direita. 0 processamento do par estereoscópico é então realizado e as imagens são armazenadas em bancos de memória de vídeo em segundo plano (não 
visíveis). Movidos para exibição em primeiro plano (tornam-se visíveis), esses bancos de memória ficam livres para receber o próximo par estéreo processado. Assim, a cada ciclo de processamento as imagens armazenadas em segundo plano são exibidas ao serem passadas para o primeiro plano, e em seguida os bancos de memória do segundo plano recebem um novo par estéreo processado. A comutação entre as imagens esquerda e direita do par estereoscópico é feita automaticamente pelas rotinas gráficas da OpenGL após a configuração de variáveis específicas do sistema [STEREOGRAPHICS, 1997a].

\subsubsection{Rotinas de Atuação Háptica}

O objetivo das rotinas de atuação háptica é receber variáveis de posicionamento espacial e relacionadas às forças de atuação e calcular os vetores de forças de reação. Essas rotinas são executadas em paralelo às demais rotinas do sistema e permitem que sejam reconhecidas colisões entre 0 objeto tátil e os objetos presentes na cena tátil, e também que 0 dispositivo háptico exiba comportamentos dependentes ou não de geometrias.

Para o controle e programação do dispositivo háptico foi utilizado o conjunto de bibliotecas GHOST. Esse pacote permite programar 0 dispositivo háptico Phantom, modelar o espaço virtual háptico e atribuir características aos objetos nele presentes. Então, rotinas de detecção de colisão e cálculo de forças são executadas automaticamente, sendo que algumas podem ser (re)definidas adicionando ou alterando propriedades de objetos. Este pacote utiliza o conceito de cena háptica, espaço tridimensional onde objetos são inseridos como nós e respondem a comportamentos definidos. Esses nós podem representar formas, comportamentos dinâmicos, efeitos de força, transformações (translações, rotações, escala) ou interfaces hápticas. 0 laço háptico (seção 2.4), por sua vez, é uma tarefa independente executada a uma taxa máxima de $1 \mathrm{KHz}$. 
Para a composição do ambiente háptico do simulador de transplante de medula óssea foi definida uma cena principal e a ela foram adicionados os objetos: modelos das camadas e o dispositivo háptico, conforme mostra a Figura 28. Os modelos foram agrupados pelo nó corpo associado à cena.

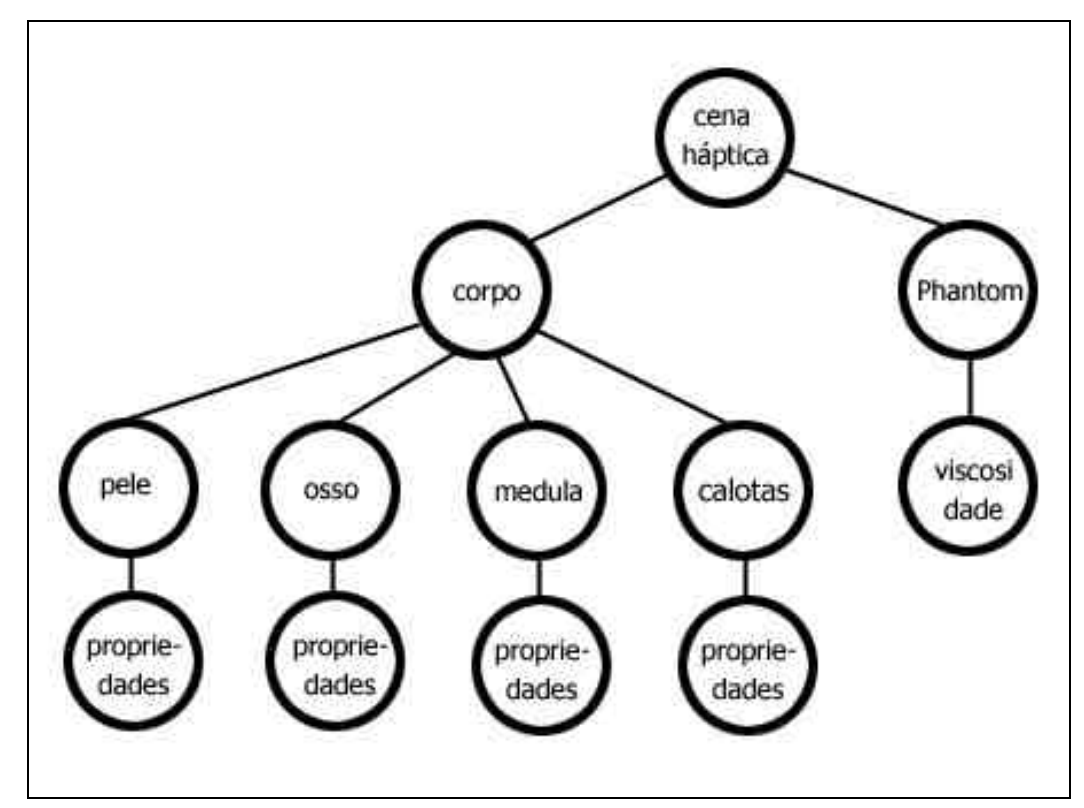

Figura 28: Diagrama da cena háptica definida no simulador de coleta de medula óssea.

Para os modelos do corpo, foram modeladas as seguintes propriedades físicas: textura, elasticidade, rigidez e densidade. As propriedades de textura ou rugosidade foram simuladas a partir dos recursos de atrito estático e dinâmico suportados pelo GHOST. Já o efeito de elasticidade foi obtido utilizando uma variável de resistência transferida internamente pelo GHOST para um modelo massa-mola.

Para a obtenção da sensação de rigidez dos tecidos dos modelos a rotina de detecção de colisão precisou ser redefinida para permitir que a interface háptica pudesse penetrar os modelos. Essa propriedade foi alcançada sobrescrevendo a rotina de detecção de colisão contida no GHOST. Assim, a nova rotina foi sobreposta à anterior e a interface háptica pode não 
somente penetrar os modelos na cena, mas também estabelecer diferentes graus de resistência para cada camada. Nessa rotina foi determinado um valor de limiar para a força aplicada sobre o dispositivo háptico, que uma vez ultrapassado desabilita temporariamente a resistência do dispositivo e permite a penetração no modelo.

Os dispositivos hápticos atuais trabalham com o conceito de cascas ou modelos fechados, onde as propriedades atribuídas aos objetos são relativas à superfície destes. Assim, um objeto não fechado apresentará apenas um lado e, conseqüentemente, as mesmas características em toda a sua superfície. Os objetos fechados por sua vez, apesar de apresentarem uma única característica em toda a sua casca, possuem uma região interna que pode ser explorada. Essa região é tratada pelos pacotes de programação de dispositivos hápticos como uma região do espaço delimitada por uma geometria, mas não pertencente à essa geometria. Para a simulação de um número maior de camadas e não somente três, como sugere o número de modelos, foram utilizados os três modelos mais a região interna ou intermediária destes. Desse modo, foi possível simular seis camadas diferentes com o uso das três cascas dos modelos (que são fechados) mais o interior de cada uma delas. Então, durante a interação, uma vez ultrapassado o limiar de força estabelecido para a camada em questão (a casca da camada é ultrapassada) foi atribuída uma propriedade de densidade ao objeto háptico, alterando o seu movimento até o momento de saída dessa camada ou entrada em uma nova camada. Para essa propriedade foi escrita uma rotina que utilizou a fórmula da viscosidade (4), onde $\mathbf{F}$ é a força resultante obtida com a multiplicação de um coeficiente de resistência $\mathbf{k}$ pela velocidade $\mathbf{V}$. Nesse caso, a velocidade é um dos valores monitorados no dispositivo háptico.

$$
\mathrm{F}=-\mathrm{k} * \mathrm{~V}
$$

Portanto, as propriedades dependentes de geometria, como textura, elasticidade e rigidez, foram associadas diretamente ao modelo 
correspondente e a propriedade independente dessa geometria (densidade) ficou associada diretamente ao dispositivo háptico (Figura 28).

\subsubsection{Programação das Propriedades Físicas Iniciais}

Simuladores de técnicas cirúrgicas que utilizam dispositivos hápticos para oferecer retorno de força relativo aos tecidos manipulados dependem do conhecimento das propriedades mecânicas desses tecidos. Atualmente, essas propriedades são obtidas a partir de cadáveres ou animais sacrificados [OTTENSMEYER et al., 2000]. Com o objetivo de determinar essas propriedades em seres vivos estudos recentes vêm sendo desenvolvidos [BROWN et al., 2002] [OTTENSMEYER, 2002] [TAY et al., 2002] [BROUWER et al., 2001]. Esses estudos envolvem a determinação de coeficientes como elasticidade, resistência e densidade, dentre outros. Um dos fatores observados nessas pesquisas é que as propriedades de tecidos mortos apresentam diferenças em relação aos tecidos vivos, o que pode ser observado se comparados os valores obtidos em cobaias vivas e cobaias sacrificadas [HOLTON, 2001]. Apesar dos avanços, ainda busca-se formas de obter esses valores característicos dos tecidos em seres humanos vivos.

Visto que ainda não são conhecidas as grandezas das propriedades mecânicas dos tecidos humanos necessárias para a calibragem das propriedades, as propriedades físicas iniciais atribuídas aos modelos basearam-se em uma descrição subjetiva feita por um especialista das sensações sentidas durante a coleta da medula em procedimentos reais. Assim, foram atribuídos às camadas valores baseados na compreensão de descrições feitas por especialistas em coleta de medula óssea. Essas características relacionam-se com as sete camadas presentes no local de coleta da medula óssea e já descritas anteriormente em 4.2.3. 
Conforme previsto no projeto, um especialista em coleta de medula óssea foi o responsável pela calibragem final, adequando essas propriedades à realidade (seção 4.5).

\subsubsection{Sincronização das Rotinas de Visualização e Háptica}

As bibliotecas de programação de dispositivos hápticos prevêem, na sua maioria, a criação ou importação de objetos tridimensionais para manipulação tátil no espaço, associando automaticamente aos objetos um modelo visual. No entanto, na maioria dessas bibliotecas não existe suporte à visualização estereoscópica, o que exigiu a programação de rotinas separadas de visualização e manipulação tátil para o simulador de coleta de medula óssea.

Para a importação dos modelos utilizados nas rotinas de visualização, foi gerada uma função que importou os modelos previamente definidos e salvos no formato VRML e armazenou os pontos e polígonos a serem utilizados no processamento das imagens em uma estrutura de dados. Para o processamento da rotina háptica, o GHOST, conjunto de bibliotecas para programação do dispositivo háptico, importou os modelos VRML e colocouos em um mundo tridimensional predefinido e não configurável. Essa rigidez na apresentação do mundo tridimensional háptico gerou uma total incompatibilidade entre 0 que 0 usuário observava e o que ele tocava durante a simulação. A compatibilidade dos mundos foi obtida tornando as dimensões do mundo visual e a posição do observador proporcionais às mesmas pré-definidas pelo GHOST para o mundo tátil.

A principal inconveniente desse processo foi a utilização de estruturas de dados e rotinas de leitura separadas para a importação dos modelos em cada mundo (visual $X$ tátil). No entanto, isso permitiu que o conjunto de modelos táteis fosse reduzido em número de pontos e polígonos, conforme descrito na sessão 4.2, o que aumentou o desempenho da aplicação final. 
A sincronização entre as rotinas foi feita com a dependência da rotina de visualização em relação à rotina háptica, fazendo com que a rotina de visualização permaneça em um laço infinito com chamadas à rotina háptica para a obtenção da posição espacial do dispositivo. A rotina háptica, por sua vez, é uma tarefa independente e executada em paralelo à rotina de visualização.

\subsubsection{Apresentação do Simulador Integrado}

O ambiente de execução do simulador está montado em um microcomputador convencional equipado com uma placa de vídeo com suporte à estereoscopia e um dispositivo háptico conectado.

O ambiente de trabalho conta com um sistema de menus e uma barra de informações na parte inferior. No menu o usuário pode selecionar o módulo da simulação que deseja praticar. Dependendo do módulo, opções de ativação e desativação da estereoscopia e do dispositivo háptico são habilitadas nas opções seguintes da barra do menu. Além disso, é possível ajustar a paralaxe para tornar a visualização estereoscópica mais confortável (Figura 29). Também é possível desabilitar a estereoscopia durante o Módulo de Observação da Anatomia. As opções do menu e submenus são ativadas e desativadas de acordo com o módulo em execução. Como exemplo, o menu "Estéreo" permanece inativo quando a estereoscopia está desativada e não permite a desativação da estereoscopia nos módulos de Localização e Coleta.

A barra localizada na parte inferior da janela disponibiliza informações sobre - módulo em execução, o estado do dispositivo háptico (LIGADO/DESLIGADO), a sua posição espacial e angulação, bem como o ajuste de paralaxe. 


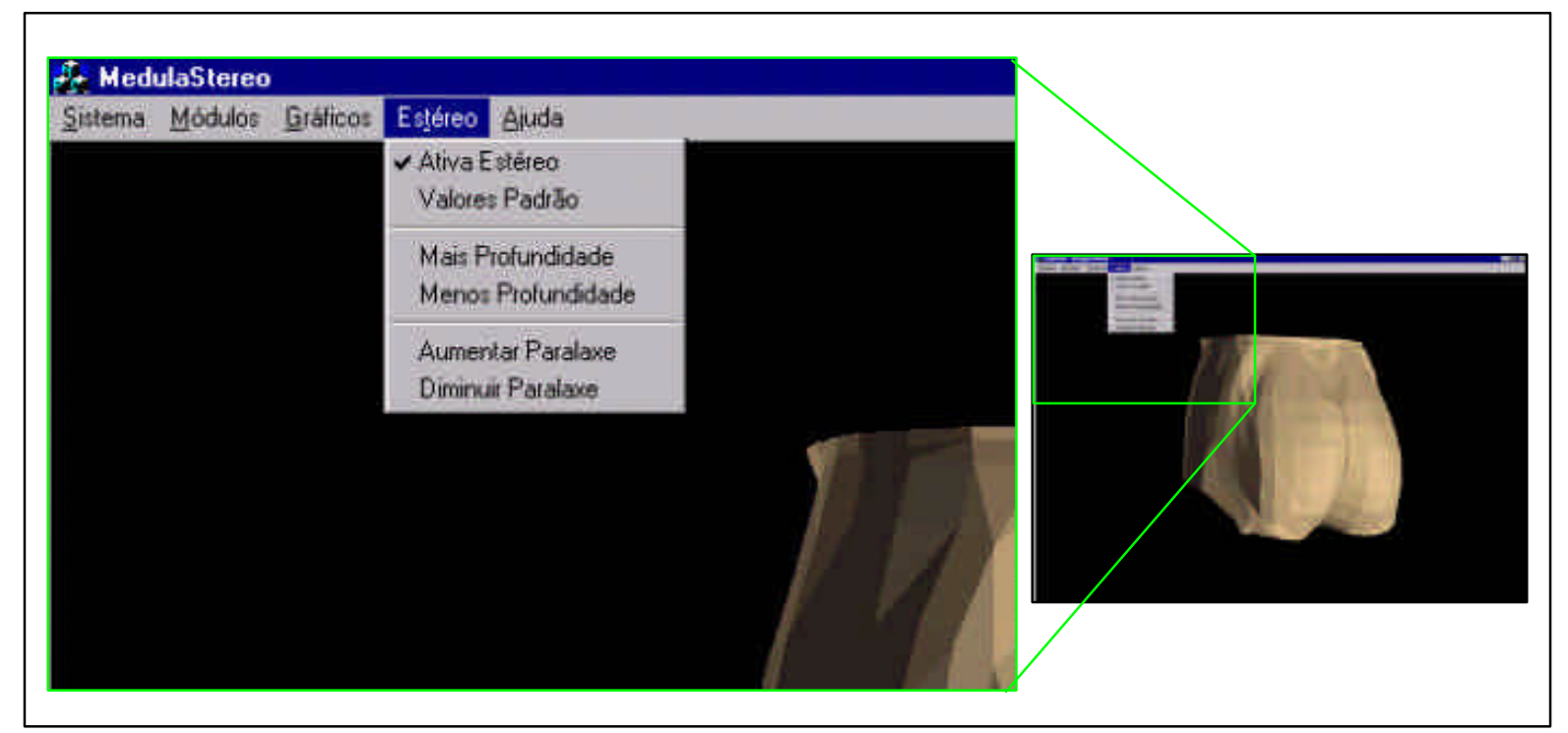

Figura 29: Detalhe do menu superior do sistema com as opções de ajuste de estereoscopia visual.

Os módulos são executados na mesma ordem da realização do procedimento real de coleta de medula óssea. Dessa forma, inicialmente é executado o Módulo de Observação da Anatomia onde o modelo completo da bacia (pele, osso e medula) pode ser observado e movimentado com três graus de liberdade. Neste módulo estão disponíveis as opções de visualização estereoscópica e visualização interna. A seguir, o Módulo de Localização, permite que o usuário utilize o dispositivo háptico para tocar 0 modelo e identificar a localização das cristas ilíacas. Neste módulo o dispositivo háptico é representado como um dedo na visualização, onde a estereoscopia está ativada. 0 módulo seguinte é o Módulo de Coleta, no qual uma agulha representa o dispositivo háptico. Com 0 auxílio do dispositivo háptico o usuário pode penetrar no modelo e identificar com 0 toque o momento em que a medula óssea é alcançada.

Os três módulos e a seqüência de execução dos mesmos pode ser observada na Figura 30. A Figura 31 apresenta o sistema final sendo utilizado por um médico oncologista. 


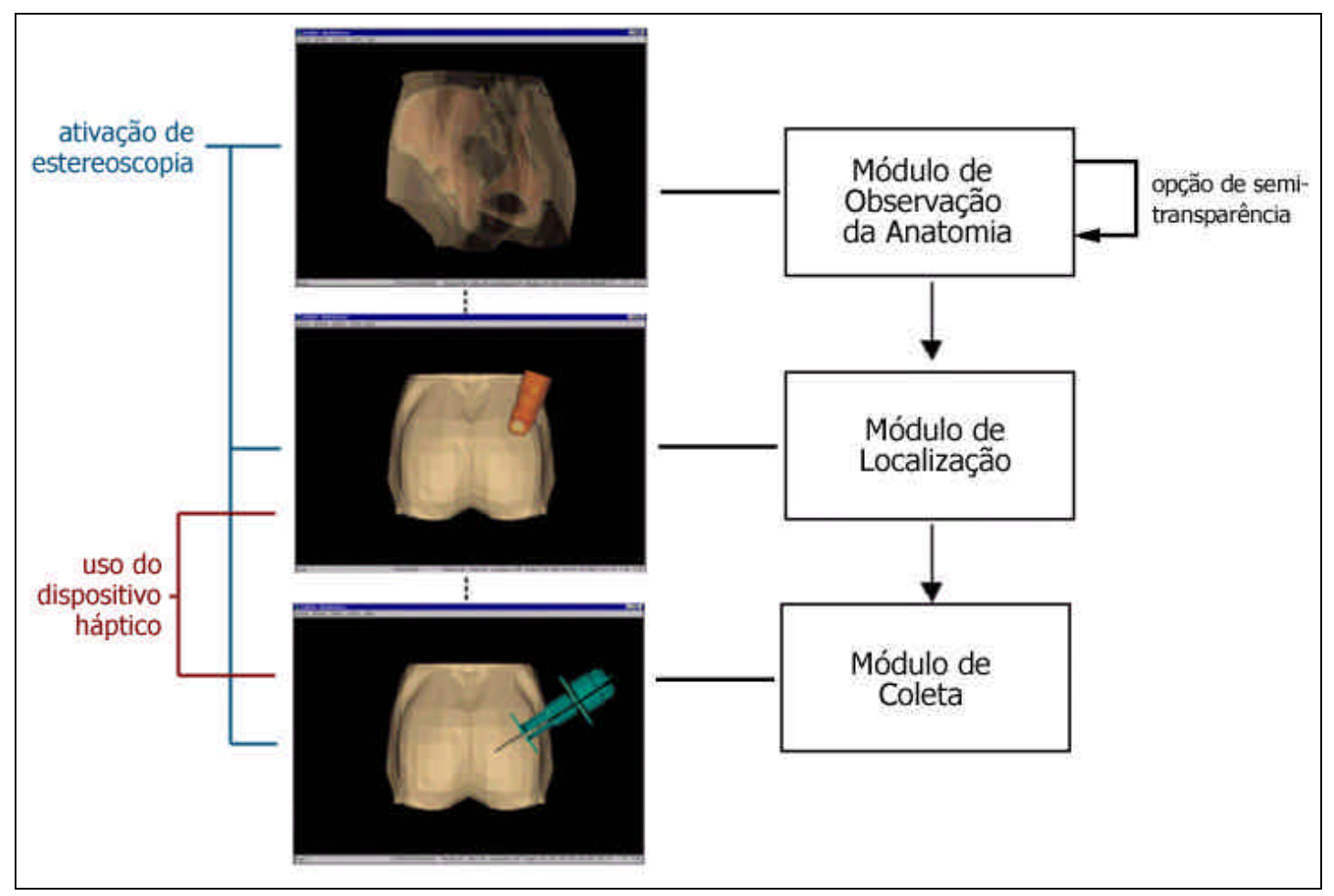

Figura 30: Diagrama com a seqüência de execução dos módulos do simulador de coleta de medula óssea e as imagens da tela correspondentes.

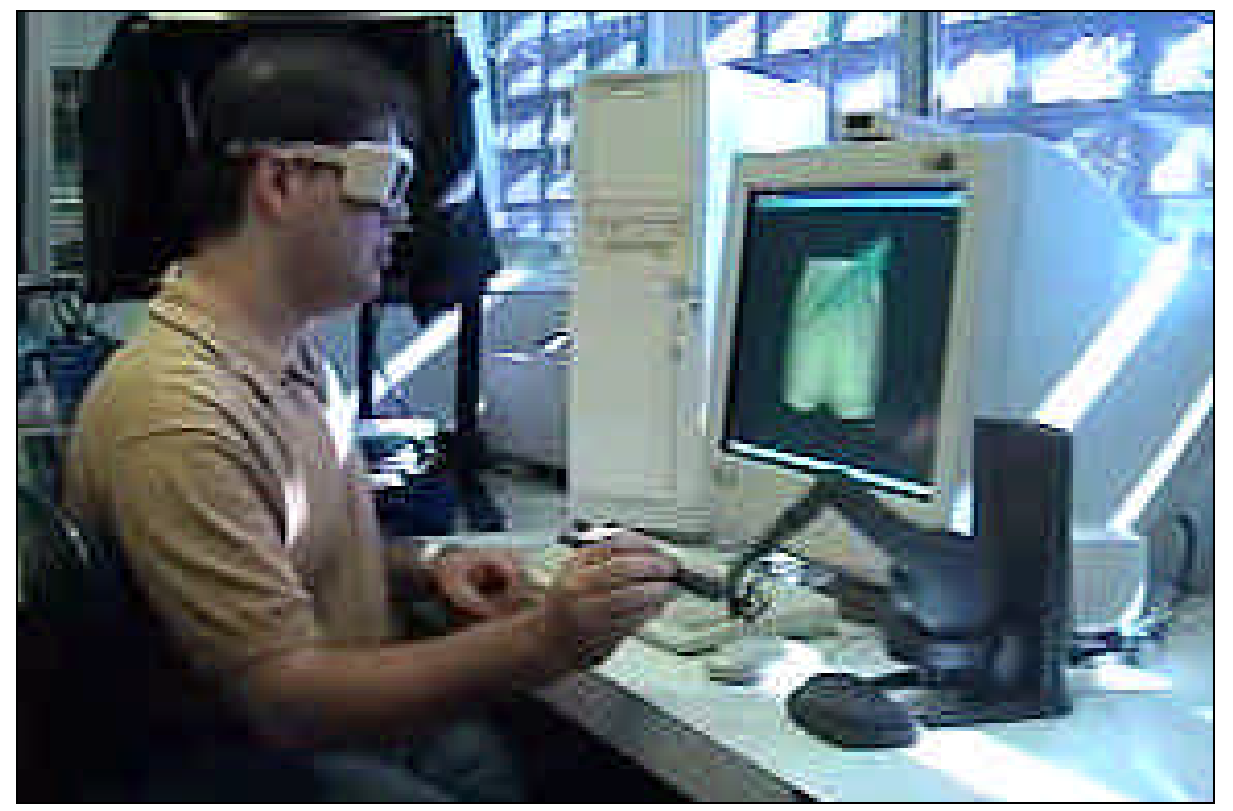

Figura 31: Oncologista utilizando o simulador de coleta de medula óssea baseado em RV. 


\subsection{Calibragem das Propriedades Físicas}

Após a conclusão das etapas de modelagem e implementação dos módulos do simulador, a primeira calibragem das propriedades físicas dos modelos presentes no sistema precisou ser feita. Essas propriedades deveriam refletir as sensações táteis resultantes da manipulação dos modelos, mas são desconhecidas numericamente.

Em 2001, Holton apresentou valores numéricos para as propriedades de elasticidade e dureza relacionadas à pele de cobaias (porquinhos-da-índia) durante uma punção, mas salientou o fato de os valores terem sido coletados em média 12 horas após o sacrifício dos animais, o que provocou alteração em relação aos valores medidos nos organismos vivos [HOLTON, 2001]. No caso de seres humanos, esses valores ainda não são conhecidos e apenas médicos habituados à execução do procedimento de coleta de medula óssea podem descrever as sensações táteis relacionadas a essa tarefa. Sendo assim, foi criado um sistema específico para a calibragem das características. Nesse sistema, um médico experiente verificou diferentes propriedades em objetos de mesma forma geométrica e apontou aquela que mais se assemelhava à de um determinado tecido do modelo existente no simulador. As propriedades inicialmente apresentadas procuraram abranger a escala de forças do dispositivo háptico utilizado e posteriormente foram refinadas conforme as escolhas subseqüentes feitas pelo médico.

O sistema de calibragem (Figura 32) apresenta em 3D três cubos geometricamente idênticos. Com o dispositivo háptico, no entanto, é possível sentir as diferenças materiais presentes nos cubos.

Em uma primeira etapa de calibragem o médico pôde tocar os três cubos e identificar aquele cujas propriedades de elasticidade e textura de pele mais se assemelhavam ou aproximavam da camada de pele. Na segunda etapa o médico pôde perfurar três cubos e identificar a rigidez e a densidade mais 
semelhante à pele e seu interior (derme e subcutâneo). Todas as propriedades dos cubos, tanto na primeira quanto na segunda etapa foram definidas para inicialmente abrangerem a faixa de valores possível de ser simulada pelo dispositivo háptico. Esses passos repetiram-se para as camadas de osso e medula óssea. Os cubos escolhidos foram então utilizados para o refinamento das propriedades para uma segunda fase de calibragem, acontecendo o mesmo para uma terceira fase, quando 0 médico concluiu que as propriedades estavam adequadas.

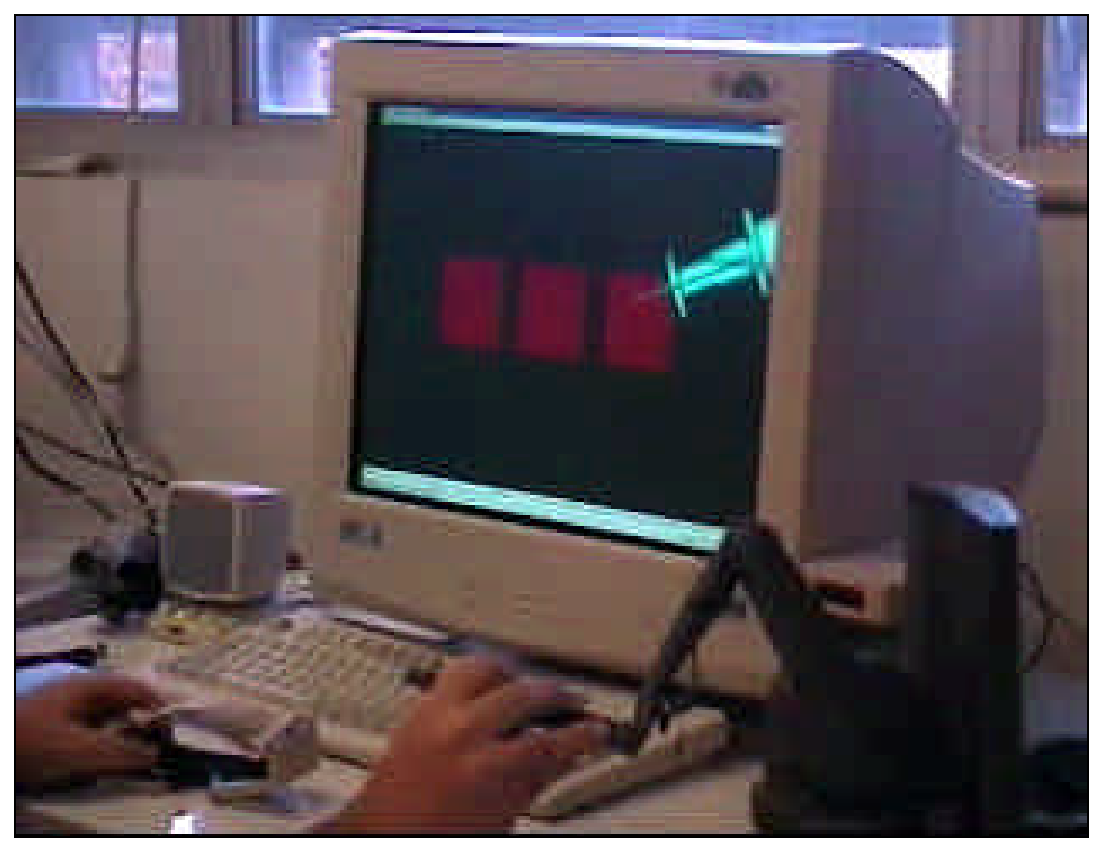

Figura 32: Sistema de calibragem das propriedades táteis. Cada cubo vermelho na tela apresenta características físicas diferentes que podem ser percebidas com o uso do dispositivo háptico.

Ao todo foram calibradas as propriedades físicas de textura, elasticidade, rigidez e densidade relacionadas às seis camadas, sendo três cascas e seus interiores, abrangendo todas as camadas definidas no simulador (seção 4.4.3).

As propriedades definidas foram então exportadas como características dos modelos utilizados no simulador de coleta de medula óssea, onde a 
biblioteca do dispositivo háptico utilizou os valores para gerar automaticamente as características durante a manipulação. Entretanto, para a geração do efeito de perfuração e densidade das camadas, os valores definidos pelo médico durante a calibragem foram exportados para as rotinas escritas e chamadas durante a simulação.

\subsection{Conclusão}

Este capítulo abordou todos os aspectos relacionados ao desenvolvimento de um simulador para o treinamento em coleta de medula óssea, desde a análise dos requisitos do sistema e concepção dos modelos utilizados até a sua implementação.

O sistema desenvolvido apresenta três módulos principais onde é possível estudar a anatomia e treinar as etapas de palpação e perfuração do corpo para coleta de medula óssea. Uma vez que o procedimento real não oferece informação visual do interior do corpo do paciente, na simulação foi utilizado um dispositivo háptico para a simulação das sensações relacionadas ao toque e ao movimento durante a execução do procedimento.

Uma vez que não são conhecidos os valores numéricos para as propriedades de elasticidade e dureza relacionadas à pele humana, foi apresentado um sistema desenvolvido especificamente para o processo de calibragem das propriedades táteis dos objetos presentes no simulador. Nesse sistema, um médico experiente pode experimentar diferentes propriedades em objetos táteis, apontando aquelas que mais se assemelhavam às dos tecidos reais, 0 que permitiu adequar as propriedades dos objetos do simulador. 
5 Análise e Avaliação dos Resultados 


\subsection{Introdução}

Neste capítulo é feita uma análise e descrita a avaliação do simulador de coleta de medula óssea. 0 objetivo é não só oferecer um comparativo do sistema desenvolvido com o método tradicional de treinamento da modalidade de coleta de medula óssea e com outros sistemas de simulação presentes na literatura, mas também permitir que a comunidade médica, usuária final, possa avaliá-lo e fornecer suas impressões.

Aprimoramentos a serem considerados no simulador de coleta de medula óssea também são abordados.

\subsection{Análise Comparativa dos Métodos de Treinamento Tradicional e Proposto}

No treinamento tradicional de coleta de medula óssea, os médicos utilizamse de cobaias (porquinhos-da-índia) que possuem semelhanças na região de interesse da coleta, em relação aos seres humanos, quanto à anatomia e às propriedades dos tecidos. Nesse tipo de treinamento, o estudante perfura a cobaia várias vezes com uma agulha procurando localizar corretamente a medula óssea. O uso de uma cobaia é limitado a um determinado número de perfurações, após o qual a cobaia é inutilizada. Neste sentido, o simulador proposto e desenvolvido apresenta como principal vantagem a possibilidade de inúmeros treinamentos sem a necessidade de reposição dos materiais. Além disso, o sistema pode ser ativado e utilizado independente de hora e disponibilidade de material (no caso, as cobaias e as agulhas).

Ainda que em uma situação mais realista fossem utilizados cadáveres humanos, existe também a necessidade de que este cadáver seja de uma criança, para o treinamento de casos relacionados à pediatria. Outro ponto a ser considerado trata das diferenças quanto às propriedades dos tecidos. 
Nesse caso um corpo cadavérico apresenta alterações físicas relacionadas aos tecidos, segundo relatado por Holton [HOLTON, 2001]. Portanto, o sistema de simulação apresenta como diferencial o fato de que o corpo simulado pode ter as suas propriedades físicas calibradas por um especialista de acordo com as de uma criança viva.

O simulador apresenta ainda um incremento ao treinamento tradicional com cobaias, pois permite o estudo prévio tridimensional da anatomia interna e externa da região pélvica.

Outras comparações entre o simulador desenvolvido e o método tradicional de treinamento em coleta de medula óssea podem ser feitas levando-se em conta os custos de armazenamento de cadáveres e a disponibilidade de cobaias para o treinamento tradicional. Neste caso, o simulador desenvolvido apresentaria custos de uma eventual manutenção dos equipamentos, que uma vez funcionando, mantêm o sistema totalmente disponível para treinamento.

O sistema desenvolvido utiliza uma plataforma computacional relativamente acessível (por volta de $\mathrm{R} \$ 3500,00$ ), à exceção do dispositivo háptico, que ainda possui custo elevado. Visto que a tecnologia de dispositivos hápticos vem evoluindo rapidamente, acreditamos que em um curto espaço de tempo dispositivos dessa natureza tenham seu custo reduzido. Como exemplo, citamos o próprio dispositivo háptico utilizado, que teve seu custo diminuído em $40 \%$ em um período de três anos.

Enfim, a principal vantagem do simulador é oferecer um treinamento que apresenta as mesmas características, em termos cognitivos, de um procedimento real realizado em crianças. Acreditamos que essas características, aliadas à disponibilidade do simulador, permitirão um melhor preparo de médicos novatos para a realização da coleta real. 


\subsection{Análise Comparativa do Simulador de Coleta de Medula Óssea com outros Simuladores}

Simuladores para a medicina visando o treinamento médico oferecem uma opção realista para diferentes modalidade das medicina. Alguns desses simuladores utilizam imagens adquiridas por tomografia computadorizada ou ressonância magnética para a composição tridimensional de um órgão ou região do corpo humano, como é o caso de [DELLINGETTE, 1994] e [ZIEGLER et al., 1995]. Observa-se nesses sistemas a preocupação com 0 aspecto visual, que pode ser evidenciada com a geração de imagens estereoscópicas detalhadas do objeto [YAGEL et al., 1996] ou com a possibilidade de movimentação tridimensional interativa [TSAl et al., 2001], em alguns casos inclusive com deformação dos objetos em tempo-real [SZÉKELY et al., 1999]. Dependendo da qualidade das imagens e do nível de detalhamento presente nos objetos torna-se necessário 0 uso de plataformas computacionais de processamento paralelo ou de alto desempenho gráfico [OPPENHEIMER et al., 2000] [KÜHNAPFEL et al., 2000].

Para sistemas que utilizam dispositivos hápticos na interação usuáriomáquina, a preocupação maior no desenvolvimento parece ser quanto à qualidade do retorno de força ou a deformação dos objetos tocados [BURDEA et al., 1998] [GORMAN et al., 2000]. Nestes casos, os objetos utilizados não resultam de volumes reconstruídos a partir de imagens médicas e a visualização não é estereoscópica. Sistemas que reúnem estereoscopia, deformação e interação háptica são executados em plataformas computacionais de alto desempenho gráfico e oferecem um custo bastante elevado. Sistemas que reúnem essas características montados em plataformas do tipo PC utilizam modelos simplificados, nenhuma deformação ou deformação otimizada e retorno háptico ativo ou passivo (quando sons indicam o contato) [MAHONEY, 1998]. 
Um dos pontos observados em sistemas desenvolvidos para o treinamento de procedimentos em medicina é que parte desses sistemas visa a verificação da possibilidade de uso futuro destes no treinamento de uma determinada modalidade médica. Por esse motivo, o foco de estudo é a reunião de componentes tecnológicos e desempenho dos algoritmos e não necessariamente a adaptação do sistema à modalidade médica em questão [MAHONEY, 1998].

Outro fator de destaque é a não utilização de um método de calibragem das propriedades físicas dos órgãos e estruturas quando existe interação háptica. Uma vez que as propriedades físicas dos tecidos humanos envolvidos na simulação não são conhecidas, não é possível oferecer realismo nesse sentido. Assim, sistemas como os apresentados por [TAY et al. 2002] e [OTTENSMEYER et al., 2000] basearam-se em características obtidas da medição de propriedades em tecidos de cobaias mortas ou cadáveres. Outros sistemas, como [BURDEA et al., 1998], buscam apenas evidenciar as diferenças entre tecidos tocados e utilizam para as propriedades físicas valores escolhidos aleatoriamente.

Tendo como objetivo o treinamento de coleta de medula óssea, o simulador desenvolvido procurou abranger características como: baixo custo, uso de um método de interação e visualização realista, apresentação realista das propriedades físicas dos tecidos e interação com a comunidade médica e baixa latência. Assim, a plataforma computacional foi escolhida dentro de custos compatíveis com a realidade brasileira e o sistema foi concebido para aproveitar ao máximo a sua capacidade. Os modelos utilizados são derivados de estruturas genéricas do corpo humano, uma vez que estas podem representar a maioria percentual da população. As imagens são exibidas em estéreo, mas os modelos táteis (não-visíveis) foram simplificados em quantidade de polígonos, o que não afetou visualmente a aplicação, mas ofereceu um grande ganho no desempenho. Também se optou por não oferecer deformação da camada de pele, uma vez que esta é 
mínima na realidade, mas que combinada com a geração de estereoscopia e da rotina de interação háptica comprometeria o desempenho da aplicação. Como adicional, foi criado um módulo onde o usuário do simulador tem a possibilidade de explorar a região de interesse (Módulo de Estudo de Observação da Anatomia), o que acreditamos que enriqueceria o processo de treinamento do usuário.

\subsection{Avaliação do Simulador de Coleta de Medula Óssea}

Sistemas de simulação têm sido desenvolvidos no intuito de serem grandes aliados no processo de treinamento na área médica. No entanto, é importante conhecer os aspectos que validam esse sistema para a modalidade a que se destinam. Esses aspectos podem estar relacionados à credibilidade, abrangência, confiabilidade, validade e viabilidade [BERG et al., 2001].

Para o desenvolvimento do simulador de coleta de medula óssea, observouse que o aspecto mais crítico do procedimento relacionava-se à localização da medula óssea, ou seja, havia dificuldade por parte dos médicos novatos em identificar o momento em que a agulha por eles manipulada alcançava a medula óssea. Nesse caso, o fator fundamental desse processo era a aquisição de sensibilidade ligada ao sentido do tato, uma vez que não há informação visual disponível do interior do corpo do paciente. Isto estava diretamente relacionado à atribuição realista de propriedades físicas aos tecidos simulados.

\subsubsection{Teste do Simulador}

Durante a finalização do desenvolvimento do simulador, após a calibragem das propriedades, um teste preliminar do simulador foi realizado com um especialista para colher eventuais falhas e distorções do sistema. Nesse teste observou-se que o Módulo de Localização não cumpria a sua função, 
uma vez que o corpo virtual apresentava uniformidade elástica durante a palpação da pele e por essa razão não permitia identificar a localização das cristas ilíacas.

Para a solução desse problema, optou-se por adicionar dois novos objetos táteis ao sistema (seção 4.4.2). Esses objetos foram posicionados de forma a ficarem milimetricamente sobrepostos à pele na região da crista ilíaca. Quanto às propriedades físicas eles receberam as mesmas características de textura da camada de pele e de elasticidade da camada de osso.

Essa alteração permitiu adicionar descontinuidade à pele nas regiões onde o osso deveria ser perceptível sob a pele, identificando o posicionamento das cristas ilíacas e conseqüentemente aumentando o realismo da simulação.

Pelo fato de os objetos adicionados apresentarem baixa resolução não houve perdas no desempenho do sistema.

\subsubsection{Avaliação Preliminar}

Após a conclusão do simulador, uma avaliação por parte dos médicos foi realizada. Essa avaliação teve como objetivo coletar as impressões dos médicos em relação aos aspectos de credibilidade, validade e confiabilidade do sistema.

Assim, foi feita uma avaliação preliminar por um médico especialista em coleta de medula óssea [MACHADO e ZUFFO, 2003]. Para essa avaliação, tomou-se como base questionários de avaliação de sistemas imersivos [IJSSELSTEI] $N$ et al., 2000] e de outros simuladores de procedimentos médicos [MCCARTHY et al., 1999]. Foram então formuladas 9 perguntas tendo como resposta uma escala discreta compreendida entre os extremos muito positivo (nota 10) e muito negativo (nota 0) quando aplicável. As perguntas formuladas e respectivas notas são apresentadas na Tabela 2 . 
Tabela 2: Questionário de avaliação do sistema e as respostas obtidas.

\begin{tabular}{|c|c|}
\hline Pergunta & Resposta \\
\hline $\begin{array}{l}\text { 1. Como você considera sua experiência em } \\
\text { coleta/transplante de medula óssea: especialista, } \\
\text { novato, ou técnico? }\end{array}$ & ESPECIALISTA \\
\hline $\begin{array}{l}\text { 2. Você sentiu- se confortável e envolvido com a } \\
\text { simulação? }\end{array}$ & 8 \\
\hline 3. As propriedades táteis estão adequadas? & 6 \\
\hline $\begin{array}{l}\text { 4. A representação visual está adequada a um } \\
\text { treinamento inicial? }\end{array}$ & 10 \\
\hline 5. Quão similar é a visualização em relação à realidade? & 8 \\
\hline $\begin{array}{l}\text { 6. Você considera importante/ válido o estudo prévio da } \\
\text { anatomia conforme apresentado no sistema? }\end{array}$ & SIM \\
\hline $\begin{array}{l}\text { 7. Como você classifica o ambiente em termos de } \\
\text { interação? }\end{array}$ & FÁCIL \\
\hline $\begin{array}{l}\text { 8. Quão similar é a forma de interação/ manipulação se } \\
\text { comparada com a realidade? }\end{array}$ & 5 \\
\hline 9. Como você classifica o sistema em geral? & 7 \\
\hline Avaliação Geral do Sistema & 7 \\
\hline
\end{tabular}

Um especialista em coleta de medula óssea apreciou as diversas características do sistema, bem como a sua totalidade através desse breve questionário. Nessa avaliação o médico relatou que o fato de ser possível treinar em um ambiente similar ao da realização do procedimento real desperta motivação, uma vez que elimina a necessidade da compra e uso de cobaias para essa tarefa.

Outro aspecto observado relaciona-se ao conforto na execução do treinamento (pergunta 2). Nesse caso foi citado que o uso de uma mesa de visualização (seção 5.5.1) ofereceria ao usuário do sistema uma posição de 
treinamento similar à adotada durante o procedimento real de coleta de medula.

A baixa pontuação recebida na simulação de toque demonstrou a necessidade de uso de um dispositivo háptico com maior capacidade de retorno de força e um eventual esforço adicional da modelagem. Atualmente, o dispositivo háptico utilizado apresenta limitações quanto ao retorno de força (máximo de $1.7 \mathrm{~N}$ ) e não é capaz de simular a resistência e dureza do osso humano, o que não permitiu associar a característica física adequada ao modelo da camada de osso. Quanto às demais camadas utilizadas (pele e medula óssea), as propriedades foram atribuídas de forma considerada totalmente satisfatória. Outra limitação do dispositivo háptico foi quanto à não fixação dos movimentos de rotação nos eixos XYZ (torque), pois o mesmo não apresenta retorno de força para movimentos de rotação. I sso fez com que a inserção da agulha no modelo acontecesse sem a fixação do ângulo após a penetração desta no corpo virtual. Essa limitação permite ao usuário a mudança do ângulo livremente, o que não é possível no procedimento real.

Os modelos visuais utilizados no sistema receberam uma pontuação bastante alta (pergunta 4), sendo que existe a necessidade de melhorar a camada mais externa (pele) para que os triângulos do modelo não sejam perceptíveis visualmente. 0 possível uso de modelos realistas adquiridos por tomografia computadorizada não foi visto como uma adaptação necessária devido ao fato de não existirem diferenças anatômicas significativas entre seres humanos nessa região do corpo.

Como plataforma de visualização, o uso de óculos obturadores combinados com um monitor de vídeo convencional apresentou-se como uma opção confortável e fácil de usar, não impedindo o uso de óculos convencionais (para correção de grau) sob os óculos obturadores. Além disso, a possibilidade de visualização do treinamento realizado pelo usuário por 
outras pessoas permite 0 acompanhamento da simulação por um médico especialista ou até mesmo por outros médicos iniciantes.

A presença de uma etapa de estudo da região de interesse, disponibilizada no Módulo de Observação da Anatomia, mostrou-se bastante satisfatória, pois complementa o estudo teórico e prepara o usuário para o treinamento.

Para o Módulo de Localização surgiu a necessidade de adicionar um novo dispositivo de interação com retorno de força que permitisse o toque do corpo humano de maneira mais natural. Isto porque esta etapa da simulação baseia-se na palpação da região, onde a ponta dos dedos é utilizada no procedimento real. Nesse caso, o ideal seria o uso adicional de uma luva de dados com reação tátil para a mão esquerda.

Conforme demonstrou essa avaliação inicial, o sistema apresenta grande potencial e mostrou-se motivador o estudo da técnica de coleta de medula óssea pelo seu uso.

\subsection{Aprimoramentos}

Sendo o Simulador de Coleta de Medula Óssea um primeiro protótipo de um simulador para treinamento, alguns aprimoramentos relacionados à visualização e aquisição de conhecimento por parte do usuário foram identificados como sendo fatores de aumento do realismo e utilidade do sistema. São eles: a adoção de uma mesa de visualização e a incorporação de um módulo de avaliação de desempenho do usuário.

\subsubsection{Mesa de Visualização}

O objetivo das mesas de visualização é oferecer maior realismo, aumentando o grau de imersão do usuário na observação do ambiente virtual do simulador. No caso de aplicações em cirurgia, como nesse trabalho, as mesas apresentam como principal vantagem o posicionamento 
do usuário diante do simulador de modo similar ao adotado durante a realização do procedimento real, colocando-o em uma posição mais confortável e realista.

Em uma mesa de visualização a imagem é projetada em um plano horizontal, podendo para isso ser utilizado um espelho para reflexão da imagem do monitor de vídeo (Figura 33) ou o próprio monitor posicionado com a tela para baixo.

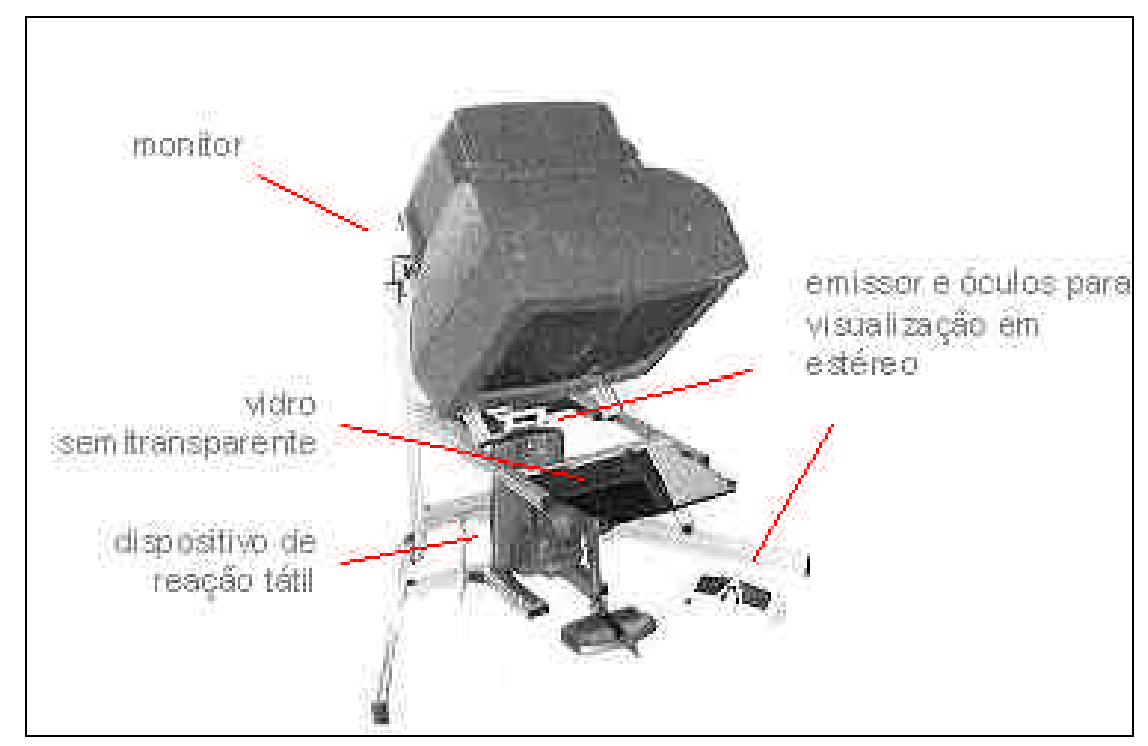

Figura 33: Esquema de montagem e disposição de equipamentos em uma mesa de visualização (http://magma.reachin.se).

A adaptação do simulador para seu uso em uma mesa de visualização foi tema de estudo para a montagem de uma nova plataforma de visualização. Como protótipo foi elaborada uma armação metálica na qual foram encaixados: um vidro semitransparente com tratamento reflexivo, o emissor de sincronização dos óculos para estereoscopia e o monitor de vídeo com a sua base de apoio para cima. Sob o vidro foi acondicionado o teclado, mouse e dispositivo háptico (Figura 34).

A integração definitiva da mesa de visualização ao simulador exige a interferência e alteração das rotinas de exibição de imagens do sistema operacional para que todas as imagens sejam apresentadas invertidas 
lateralmente, incluindo o sistema de menus e o monitoramento do mouse. Isso porque todo o sistema de menus do simulador é gerado de acordo com o sistema de janelas do Windows e precisaria ser invertido. Desse modo, uma vez refletida pelo vidro, a imagem seria visualizada na posição correta.

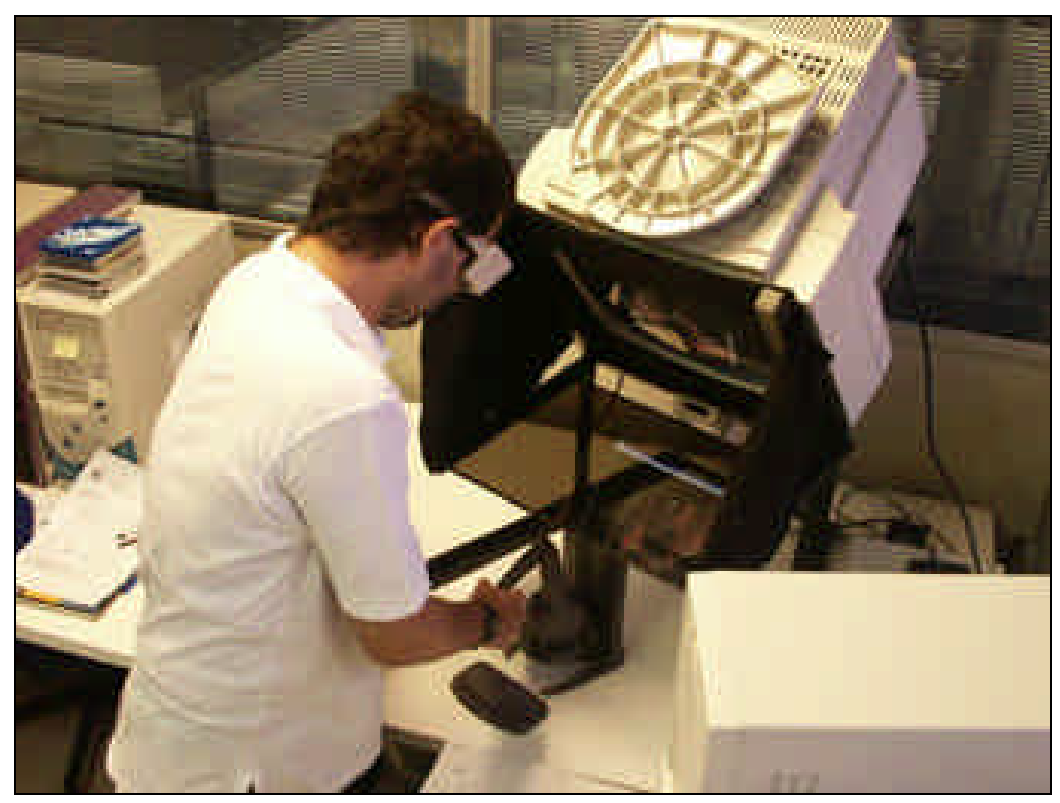

Figura 34: Protótipo da mesa de visualização para o simulador de coleta de medula óssea.

\subsubsection{Módulo de Avaliação}

O objetivo de um módulo de avaliação acoplado ao simulador seria oferecer uma classificação do desempenho do usuário em um treinamento simulado. Para tanto, seria necessário modelar o conhecimento do modo de realização do procedimento real sobre o que é certo e errado em diferentes níveis. Para essa tarefa deve ser modelado o conhecimento de um especialista sobre os modos de realização do procedimento.

Nesse método, durante a realização do treinamento simulado o módulo de avaliação captura informações durante a execução. Através de uma medida 
de distância, o módulo compara o modelo gerado por essas informações com os modelos previamente definidos e o usuário recebe um rótulo pelo módulo de avaliação. A medida de distância utilizada pode ser uma métrica, probabilidades, ou possibilidades, de acordo com a modelagem inicial realizada.

O simulador de coleta de medula óssea está preparado para receber um módulo de avaliação.

\subsection{Conclusão}

Este capítulo apresentou uma análise comparativa do método de coleta de medula óssea simulado em relação ao método real de execução do procedimento. Nesse contexto, o simulador de coleta de medula óssea apresenta como vantagens: a possibilidade de treinamento em um ambiente que simula as condições de realização do procedimento real (e não o seu treinamento) apresentando objetos com propriedades físicas semelhantes às de uma criança; a disponibilidade, pois não depende do uso de cobaias; e o enriquecimento do processo de aprendizado com a possibilidade de observação e estudo da anatomia em três dimensões.

Também foram discutidas neste capítulo as características do simulador em relação a outros simuladores para medicina encontrados na literatura, destacando as particularidades presentes nesse trabalho, como: baixo custo, o que viabiliza sua implantação; utilização de um método de interação e visualização realista; apresentação realista das propriedades físicas dos objetos; e interação com a comunidade médica.

0 teste inicial realizado e que serviu para inserir melhorias no simulador foi apresentado. Uma avaliação preliminar para verificar as impressões de especialistas sobre o simulador foi realizada e ofereceu dados para uma análise de credibilidade, validade e confiabilidade do sistema. A partir dessa avaliação foram expostas propostas de aprimoramentos. 
6 Conclusão e Trabalhos Futuros 


\subsection{Introdução}

Neste trabalho foi proposto o estudo de conceitos sobre a concepção e implementação de sistemas de realidade virtual e o desenvolvimento de um novo método de treinamento em oncologia pediátrica para procedimentos invasivos. Desse modo, este trabalho procurou apresentar os aspectos e conceitos relacionados ao desenvolvimento de simuladores baseados em realidade virtual para a simulação de procedimentos invasivos em oncologia pediátrica.

A principal contribuição apresentada foi um estudo de caso em coleta de medula óssea, com o desenvolvimento de um simulador para o treinamento dessa modalidade.

Este último capítulo apresenta considerações sobre a pesquisa conduzida, trazendo contribuições e propostas de trabalhos futuros e de evolução do simulador desenvolvido.

\subsection{Considerações sobre a Pesquisa Desenvolvida}

Os estudos conduzidos nesta pesquisa resultaram na concepção e desenvolvimento do protótipo do primeiro simulador para procedimentos invasivos da América Latina e do primeiro simulador voltado à oncologia pediátrica que se tem conhecimento na literatura científica.

Durante a realização deste trabalho ocorreram interações multidisciplinares com profissionais da área médica e profissionais ligados às áreas de computação e engenharia voltada à simulação de procedimentos para diferentes aplicações.

O apoio de profissionais da área médica foi fundamental para que pudessem ser identificadas as reais necessidades de um sistema de treinamento. Essa interação foi obtida por meio de visitas ao Departamento de Pediatria do Hospital das Clínicas da Faculdade de Medicina da 
Universidade de São Paulo (DP-FMUSP) e contato com médicos especialistas em oncologia pediátrica. Assim, foram identificadas as áreas de interesse para o desenvolvimento de um simulador para treinamento e posteriormente caracterizado 0 transplante de medula óssea e 0 procedimento de coleta da medula óssea como primeiro desafio de desenvolvimento de um simulador. Outros procedimentos, como biópsia e transplante de fígado foram considerados como uma evolução natural no desenvolvimento de novos simuladores. Estes apresentaram como requisitos o uso de plataformas computacionais de custo muito elevado devido à complexidade dos algoritmos e também à alta da definição e quantidade de objetos necessários à simulação.

Já na fase de desenvolvimento, a participação em eventos relacionados à tecnologia háptica permitiu entrar em contato com pesquisadores da área e conhecer características relacionadas à programação desses dispositivos. Também foi possível observar o grande interesse da comunidade científica e médica no simulador devido à sua característica particular de visar a pediatria, até então não tratada em outros simuladores, devido às necessidades específicas da área. Estes contatos permitiram que em janeiro de 2001 fosse feito um estágio de duas semanas na Universidade de Stanford junto ao Center for Advanced Techniques in Surgery da Faculdade de Medicina para estudo de métodos de modelagem de objetos hápticos e métodos de interação háptica.

Dentre as linhas de pesquisa iniciadas com este trabalho, destaca-se a avaliação interativa de desempenho do usuário em treinamento simulado em ambientes virtuais. Visto que esse tipo de avaliação deve ser acoplado ao simulador, observa-se que métodos estatísticos ou baseados em raciocínio lógico, como modelos nebulosos (fuzzy) [MACHADO et al., 2000a], podem ser empregados na modelagem do conhecimento do especialista e na análise dos movimentos do usuário durante sua interação 
com o sistema objetivando oferecer um índice de desempenho do usuário do simulador.

\subsubsection{Contribuições}

Durante a realização deste trabalho, foram elaborados e apresentados artigos contendo aspectos da concepção, desenvolvimento e evolução deste estudo.

Os primeiros artigos enfocaram o estudo do problema e os requisitos para a concepção de um sistema para a simulação de procedimentos invasivos em oncologia pediátrica, já abordando o caso de transplante de medula óssea [MACHADO et al., 2000b] [MACHADO et al., 2001a]. Posteriormente foi conduzido um estudo e desenvolvida uma aplicação para síntese volumétrica de imagens médicas com visualização estereoscópica [GÓES et al., 2000] [GÓES et al., 2001]. Esse estudo permitiu observar que a existência de objetos táteis volumétricos permitiriam a atribuição de características elásticas e mecânicas heterogêneas para um modelo tridimensional, eliminando o uso de cascas homogêneas, conforme utilizado e citado na seção 4.4.2.

Uma vez identificado o problema da coleta de medula óssea, propôs-se um método de avaliação interativa do treinamento [MACHADO et al., 2000a] com 0 uso de lógica nebulosa para a modelagem do conhecimento de especialistas e posterior classificação do usuário de acordo com seu desempenho durante a simulação [MACHADO et al., 2001b]

Durante o desenvolvimento do simulador foram analisados aspectos de implementação, como a modelagem de rotinas e análise de equipamentos para visualização estereoscópica, rotinas de interação háptica e aspectos de avaliação do usuário, abordados posteriormente [MACHADO et al., 2001c]. Com a conclusão do simulador, foram apresentados detalhes relacionados à implementação de suas rotinas de interação háptica, como a atribuição das 
características físicas dos modelos utilizados, e a avaliação realizada por especialistas [MACHADO e ZUFFO, 2002]. Finalmente, o simulador completo e calibrado foi apresentado para a comunidade internacional [MACHADO et al., 2002] com a análise dos resultados e propostas de sua evolução [MACHADO e ZUFFO, 2003].

Atualmente, encontra-se em fase de elaboração um artigo completo contendo todas as etapas de desenvolvimento do simulador, desde a sua concepçào até os resultados obtidos.

\subsection{Trabalhos Futuros}

Como trabalhos futuros pretende-se continuar a fase de avaliação do sistema com mais especialistas e médicos pediatras. Esta avaliação deve servir para que sejam analisadas possíveis alterações/correções/melhorias no sistema atual. Além disso, pretende-se realizar uma comparação de populações familiarizadas e não familiarizadas com a ferramenta de simulação para avaliar o benefício do método de treinamento simulado sobre os métodos de treinamento convencionais.

A avaliação ou comparação aprofundada entre o treinamento simulado e o treinamento tradicional faz-se necessária para identificar os benefícios do uso do simulador no lugar do treinamento tradicional. Essa avaliação leva em conta fatores como habilidade adquirida e tempo para aquisição de experiência. Para a comparação entre os métodos de treinamento é necessário que dois grupos aleatórios de usuários, em condição semelhante de aprendizado, sejam treinados por um dos métodos. Posteriormente, cada aluno treinado será observado por médicos experientes durante uma coleta de medula óssea em pacientes reais. As impressões desses médicos devem ser colhidas para uma comparação estatística entre os grupos. Os médicos que irão observar os alunos não devem saber a qual método de treinamento eles foram submetidos. 
Em relação a aprimoramentos da ferramenta de simulação podemos destacar a adaptação do sistema para uso na mesa de visualização e estudo de novas plataformas de visualização. Acreditamos que o uso de uma mesa de visualização aumente o grau de imersão do usuário, colocando-o numa posição mais confortável e realista diante do sistema.

Finalmente sugerimos a incorporação de uma ferramenta para avaliação interativa do usuário [MACHADO et al., 2000a] [MACHADO et al., 2001b] que permita um acompanhamento do seu desempenho. Com o uso de uma ferramenta de avaliação seria possível executar um monitoramento preciso dos movimentos do usuário, uma vez que computacionalmente é possível observar e medir como ele manipula a agulha virtual (dispositivo háptico) no interior do modelo. Observou-se que a maioria dos simuladores apresenta ao usuário avaliações posteriores à simulação. Estas avaliações comparam a resposta do usuário do sistema a uma resposta esperada, fornecendo a porcentagem de acerto dentre os sucessivos treinamentos efetuados por um mesmo usuário [BURDEA et al., 1998]. Em outros casos, o treinamento simulado é gravado em vídeo e posteriormente avaliado por um médico experiente. No entanto, até o momento não foram encontradas referências bibliográficas que tratem de ferramentas de avaliação interativas acopladas em um sistema de simulação.

Com o desenvolvimento da tecnologia de dispositivos hápticos espera-se que novos dispositivos venham a fornecer sensações de tato além da pontual (um único ponto de contato). Para este trabalho, no entanto, pelo fato do procedimento real de coleta de medula óssea necessitar de uma agulha como ferramenta, a percepção além de um único ponto afeta apenas a fase de localização do local de inserção da agulha, fase esta onde a ponta dos dedos é utilizada.

Sabe-se que em diversos aspectos, que os estudos aqui conduzidos poderão ser estendidos para a medicina em geral e/ou outros campos da pediatria. No entanto, o contato com a comunidade médica é essencial para 
identificar os aspectos de maior relevância a serem tratados pelo sistema em desenvolvimento.

\subsection{Considerações Finais}

As pesquisas e 0 desenvolvimento de simuladores voltados para 0 treinamento médico têm se intensificado nos últimos anos. Da mesma forma, estudos relacionados a algoritmos, componentes mecânicos e metodologias que podem ser utilizadas nesses sistemas também se intensificam. Deste modo, acreditamos que nos próximos anos devam surgir dispositivos hápticos novos e com mais capacidade de retorno de força, bem como computadores pessoais e equipamentos com maior capacidade de processamento que permitam o uso e manipulação de um ou mais modelos realistas em conjunto. Também devem ser desenvolvidos novos métodos de interação háptica que tratem de volumes hápticos e otimizem os algoritmos de detecção de colisão em tempo-real. Metodologias de avaliação de procedimentos realizados em simuladores devem ser concebidas e uma vez acopladas aos sistemas permitirão um acompanhamento mais efetivo do processo de treinamento [MACHADO et al., 2000] [ROSEN et al., 2001].

Este trabalho procurou estudar as técnicas e necessidades envolvidas no desenvolvimento de um simulador para treinamento de procedimentos médicos. No Brasil este é o primeiro simulador para treinamento médico desenvolvido com recursos de realidade virtual. No mundo este é o primeiro a tratar especificamente um procedimento pediátrico, contendo as suas particularidades. Sabemos que este é apenas o começo, mas que novos estudos e trabalhos poderão e serão derivados de estudos como este, permitindo em um futuro próximo a união de realismo imersivo e interativo, confiabilidade, avaliação, credibilidade e validade em sistemas voltados para o treinamento médico. 


\section{Bibliografia}

[ACKERMAN, 1990] Ackerman, Diane. Uma História Natural dos Sentidos. $2^{\text {a }}$ ed. Rio de Janeiro: Bertrand Brasil, 1990.

[ALIAS, 2003] Alias|Wavefront - About Maya. Online em:

http://www.aliaswavefront.com/en/products/maya/. Acesso em fevereiro de 2003.

[AVILA, 1999] Avila, R.S. Haptics: From Basic Principles to Advanced Applications. SIGGRAPH'99 Course Notes. ACM SIGGRAPH, agosto, 1999. CDROM.

[AYRES, 2001] Ayres, Fabio J osé. Segmentação e Estimação da Composição Histológica da Massa Tumoral em Imagens de CT de Neuroblastomas. 2001. Dissertação de Mestrado. Escola Politécnica, Universidade de São Paulo, São Paulo.

[AZUMA, 1997] Azuma, R. A Survey of Augmented Reality. Presence: Teleoperators and Virtual Environments, 6(4), agosto, p. 355-385, 1997.

[BASDOGAN, 1999] Basdogan, C. Force Reflecting Deformable Objects for Virtual Environments. SIGGRAPH'99 Tutorial Notes \#38: Haptics: From Basic Principles to Advanced Applications. $26^{\text {th }}$ International Conference on Computer Graphics and Interactive Techniques. ACM SIGGRAPH, agosto de 1999.

[BASDOGAN, 2000] Basdogan, C. Simulating Minimally Invasive Surgical Procedures in Virtual Environments: From Tissue Mechanics to Simulation and Training. Notas de Tutorial apresentado durante o Medicine Meets Virtual Reality 2000 Conference nos Estados Unidos. Janeiro, 2000.

[BERG et al., 2001] Berg, D.; Berkeley, J.; Weghorst, S. et al. Issues in Validation of a Dermatologic Surgery Simulator. Medicine Meets Virtual Reality. Studies in Health Technology and Informatics n.81, p. 60-65. IOS Press, 2001.

[BRO-NIELSEN et al., 1999]. Bro-Nielsen, M.; Tasto, J.; Cunningham, R.; Merril, G. PreOp ${ }^{T M}$ Endoscopic Simulator: A PC-Based Immersive Training System for Bronchoscopy. Medicine Meets Virtual Reality. Studies in Health Technology and Informatics n.62, p. 76-82. IOS Press, 1999.

[BROOKS, 1999] Brooks, F.P. What's Real About Virtual Reality? IEEE Computer Graphics \& Applications, v.19, n. 6, p. 16-27, novembro, 1999.

[BROUWER et al., 2001] Brouwer, I.; Ustin, J.; Bentley, L.; Sherman, A.; Dhruv, N.; Tendick, F. Measuring In Vivo Animal Soft Tissue Properties for Haptic Modeling in Surgical Simulation. Medicine Meets Virtual Reality. 
Studies in Health Technology and Informatics n.81, p. 69-74. IOS Press, 2001.

[BROWN et al., 2002] Brown, J.D.; Rosen, J.; Moreyra, M.; Sinanan, M.; Hannaford, B. Computer Controlled Motorized Endoscopic Grasper for In Vivo Measurement of Soft Tissue Biomechanical Characteristics. Medicine Meets Virtual Reality. Studies in Health Technology and Informatics n.85, p. 71-73. IOS Press, 2002.

[BURDEA, 1996] Burdea, G.C. Force and Touch Feedback for Virtual Reality. New York, John Wiley \& Sons, 1996.

[BURDEA et al., 1998] Burdea, G.; Patounakis, G.; Popescu, V.; Weiss, R. Virtual Reality Training for the Diagnosis of Prostate Cancer. Virtual Reality Annual International Symposium Proceedings, p. 190-197. IEEE, 1999.

[COHEN e CHEN, 1999] Cohen, A.; Chen, E. Six Degree-of-freedom haptic System as a Desktop Virtual Prototyping Interface. Proceedings of ASME Winter Annual Meeting. Dynamic Systems and Control, v.67, p. 401-402. Nashville/Tennesse, novembro de 1999.

[COHEN et al., 1999] Cohen, M.; Correa, J .A.L.; Lopez, J.P.; Löff, R. Utilização de VRML e Java para Visualização de Desvios Patológicos da Coluna Vertebral. Anais do $2^{\circ}$ Workshop Brasileiro de Realidade Virtual, p. 247-248. Marília/SP, 1999.

[DELINGETTE et al., 1994] Delingette, H.; Subsol, G., Cotin, S.; Pignon, J. A Craniofacial Surgery Simulation Testbed. Rapport de Recherche $\mathrm{N}^{\circ} 2199$, INRIA, fevereiro de 1994.

[DELP et al., 1990] Delp, S.L.; Loan, J.P.; Hoy, M.G.; Zajak, F.E.; Topp, E.L.; Rosen, J.M. An Interactive Graphics-Based Models of the Lower Extremity to Study Orthopaedic Surgical Procedures. IEEE Transaction on Biomedical Engineering, 37(8), p. 757, 1990.

[DELP et al., 1997] Delp, S.L.; Loan, P.; Basdogan, C.; Rosen, J.M. Surgical Simulation: An Emerging Technology for Training in Emergency Medicine. Presence (journal), v.6, n.2, p. 147-159, abril, 1997.

[DIMENSION, 2002] Force Dimension. 3DOF Delta. Online: http://www.forcedimension.com/products. Acesso em abril de 2002.

[DINSMORE et al., 1997] Dinsmore, M.; Langrana, N.; Burdea, G.; Ladeji, J. Virtual Reality Training Simulator for Palpation of Subsurface Tumors. Virtual Reality Annual International Symposium Proceedings, p. 54-60. IEEE, 1997.

[FOX, 1996] Fox, S.I. Human Physiology. $5^{\text {th }}$ edition. WCB Publishers, 1996. [GHOST, 2000] GHOST SDK API Reference, v. 3.0. Sensable Technologies Inc., 2000. CD-ROM. 
[GIBSON e MIRTICH, 1997] Gibson, S.; Mirtich, B. A Survey of Deformable Modeling in Computer Graphics. Technical Report, TR-97-19. Mitsubishi Electric Research Laboratory. Novembro de 1997.

[GÓES et al, 2000] Góes, V.P.; Machado, L.S.; Cabral, M.C.; Leitao, R.B.; Lopes, R.D.; Zuffo, M.K. Low Cost Interactive Stereoscopic Full Direct Volume Visualization of the Visible Human Dataset for Virtual Reality Medical Applications . Proceedings do $3^{\text {rd }}$ Workshop on Virtual Reality, $p$. 33-40. Rio Grande do Sul: SBC, 2000.

[GÓES et al., 2001] Góes, V.P.; Machado, L.S.; Cabral, M.C.; Leitao, R.B.; Lopes, R.D.; Zuffo, M.K. Interactive Stereoscopic Full-Color Direct Volume Visualization for Virtual Reality in Medicine. Medicine Meets Virtual Reality 2001. Studies in Health Technology and Informatics, n. 81. Amsterdam: IOS Press, 2001.

[GOMEZ et al., 1995] Gomez, D.; Burdea, G.; Langrana, N. Integration of the Rutgers Master II in a Virtual Reality Simulator. Virtual Reality Annual International Symposium Proceedings, p. 198-202. IEEE, 1995.

[GORMAN et al., 2000] Gorman, P.; Krummel, T.; Webaster, R.; Smith, M.; Hutchens, D. A Prototype Haptic Lumbar Pucture Simulator. Medicine Meets Virtual Reality. Studies in Health Technology and Informatics, $n$. 70, p. 106-109. IOS Press, 2000.

[GRIMSON et al., 1999] Grimson, W.; Kikinis, R.; J olesz, F.; Black, P. Image-Guided Surgery. Scientific American, v.280, n.6., p. 54-61, 1999.

[GUAN et al., 1998] Guan, C.G.; Serra, L.; Kockro, R.A.; Hern, N.; Nowinski, W.L.; Chan, C. Volume-based Neurosurgery Planning in the Virtual Workbench. Virtual Reality Annual International Symposium Proceedings, p. 167-173. IEEE, 1998.

[GUYTON e HALL, 1997] Guyton, A.C.; Hall, J.E. Tratado de Fisiologia Médica. $9^{\text {a }}$ edição. Guanabara Koogan, Rio de J aneiro, 1997.

[HAASE et al., 1996] Haase, H.; Strassner, J.; Dai, F. VR Techniques for the Investigation of Molecule Data. Computer \& Graphics, v.20, n.2, p. 207217, 1996.

[HALUCK et al., 2000] Haluck, R.; Webster, R.; Snyder, A.; Wang, W. Zimmerman, D.; Mohler, B.; Hutchens, D. A Haptic Surgical Suturing Simulator. Online: http://cs.millersv.edu/haptics/suture.htm. Acesso em maio de 2000.

[HALUCK et al., 2001] Haluck, R.; Webster, R.; Snyder, A.; Melkonian, M.; Mohler, B.; Dise, M.; Lefever, A. A Virtual Reality Surgical Trainer for Navigation in Laparoscopic Surgery. Medicine Meets Virtual Reality. Studies in Health Technology and Informatics, n. 81, p. 171-176. IOS Press, 2001. 
[HODGES, 1992] Hodges, L.F. Tutorial: Time-Multiplexed Stereoscopic Computer Graphics. IEEE Computer Graphics \& Applications, 12(3), p.2030, Mar. 1992.

[HODGES et al., 1995] Hodges, Larry F.; Rothbaun, Barbara O.; Opdyke, Dan; de Graff, Johannes; Williford, James S.; North, Max M. Virtual Environments for Treating the Fear of Heights. IEEE Computer, v.28, n.7, p. 27-34, julho de 1995.

[HOLTON, 2001] Holton, L. Force Models for Needle Insertion Created From Measured Needle Puncture Data. Medicine Meets Virtual Reality 2000. Studies in Health Technology and Informatics, v.81, p. 180-186. Amsterdam, IOS Press, 2001.

[HOUAISS, 2001] Instituto Antônio Houaiss. Dicionário Houaiss da Língua Portuguesa. $1^{\mathrm{a}}$ edição. Rio de Janeiro, Editora Objetiva, 2001.

[HUNTER et al., 1995] Hunter, I.; J ones, L.; Sagar, M.; Lafontaine, S.; Hunter, P. Ophthalmic Microsurgical Robot and Associated Virtual Environment. Computer in Biology and Medicine, v. 25, n. 2, pp-173-182, 1995.

[IJSSELSTEIJ N et al.,2000] Ijsselsteijn, W. Ridder, H.; Freeman, J.; Avons, S. Presence: Concept, Determinants and Measurement. Proceedings of SPIE, Human Vision and Electronic Imaging V, p.3956-3975, 2000.

[IGS, 2002] Project on Image Guided Surgery: A collaboration between the MIT AI Lab and Brigham and Women's Surgical Planning Laboratory. Online: http://www.ai.mit.edu/projects/medical-vision/surgery/surgical_navigation.html. Acesso em setembro de 2002.

[IWATA et al., 2001] I wata, H.; Yano, H.; Nakaizumi, F.; Kawamura, R. Project FEELEX: Adding Haptic Surface to Graphics. Computer Graphics Proceedings, Annual Conference, p. 469-475. ACM, 2001.

[IMMERSION, 2002a] Immersion Corporation - Laparoscopic Impulse Engine. Online:

http://www.immersion.com/products/custom/laproimpulse.shtml. Acesso em abril de 2002.

[IMMERSION, 2002b] Immersion Corporation - 3D Technologies CyberForce. Online:

http://www.immersion.com/products/3d/interaction/cyberforce.shtml. Acesso em abril de 2002.

[IWATA et al., 2001] I wata, H.; Yano, H.; Nakaizumi, F.; Kawamura, R. Project FEELEX: Adding Haptic Surface to Graphics. SIGGRAPH'2001 Proceedings, p. 469-475. ACM, 2001.

[KAUFMANN et al., 2000] Kaufmann, C.; Liu, A.; Burris, D. DTI Autostereographic Display: Initial Evaluation. Medicine Meets Virtual 
Reality. Studies in Health Technology and Informatics, n. 70, p. 156-158. IOS Press, 2000.

[KÜHNAPFEL et al., 2000] Kühnapfel, U.; Çakmak, H.; Maaß, H. Endoscopic Surgery Training using Virtual Reality and Deformable Tissue Simulation. Computers \& Graphics, v. 24, p. 671-682, 2000.

[MABREY et al., 2000] Mabrey, J.; Cannon, W.; Gillogly, S.; Kasser, J.; Sweeney, H.; Zarins, B.; Mevis, H.; Garrett, W.; Poss, R. Development of a Virtual Reality Arthroscopic Knee Simulator. Medicine Meets Virtual Reality. Studies in Health Technology and Informatics n.70, p. 192-194. IOS Press, 2000.

[MACHADO, 1995] Machado, L.S. Conceitos Básicos da Realidade Virtual. 1995. Instituto Nacional de Pesquisas Espaciais. São José dos Campos (Relatório Técnico, INPE-5975-PUD/025).

[MACHADO, 1997] Machado, L.S. A Realidade Virtual em Aplicações Científicas. Dissertação (Mestrado) - Instituto Nacional de Pesquisas Espaciais, São José dos Campos (INPE-6389-TDI/605).

[MACHADO et al., 2000a] Machado, L.S.; Moraes, R.M.; Zuffo, M.K. Fuzzy Rule-Based Evaluation for a Haptic and Stereo Simulator for Bone Marrow Harvest for Transplant. $5^{\text {th }}$ Phantom Users Group Workshop. Proceedings. Aspen/USA, outubro de 2000.

[MACHADO et al., 2000b] Machado, L.S.; Mello, A.N.; Lopes, R.D.; Odone Fo., V.; Zuffo, M.K.(2000). A Virtual Reality Simulator for Bone Marrow Harvest for Transplant . In: III Workshop Brasileiro de Realidade Virtual, 2000. Anais. Gramado/RS: SBC, 2000. p. 25-31.

[MACHADO et al., 2001a] Machado, L.S.; Mello, A.N.; Lopes, R.D.; Odone Fo., V.; Zuffo, M.K. A Virtual Reality Simulator for Bone Marrow Harvest for Pediatric Transplant. Medicine Meets Virtual Reality 2001. Studies in Health Technology and Informatics, n. 81, p. 293-297. Amsterdam: IOS Press, 2001.

[MACHADO et al., 2001b] Machado, L.S.; Moraes, R.M.; Zuffo, M.K. Avaliação "Fuzzy" para um Sistema de Realidade Virtual para Treinamento Médico.In: Encontro Nacional de Inteligência Artificial, 2001. Anais, p. 254. Fortaleza/CE: SBC, 2001. CDROM.

[MACHADO et al., 2001c] Machado, L.S.; Zuffo, M.K.; Moraes, R.M. e Lopes, R.D. Modelagem Tátil, Visualização Estereoscópica e Aspectos de Avaliação em um Simulador de Coleta de Medula Óssea. In: Symposium on Virtual Reality. Proceedings. Florianópolis/SC: SBC, outubro de 2001. p. 23-31.

[MACHADO et al., 2002] Machado, L.S.; Mello, A.N.; Odone F'., V.; Zuffo, M.K. A Virtual Reality Simulator of Pediatric Bone Marrow Harvesting Procedure. Medical Pediatric Oncology, v.39, n.4., p.282. Wiley, 2002. 
[MACHADO e ZUFFO, 2002] Machado, L.S.; Zuffo, M.K. Desenvolvimento e Avaliação de um Simulador de Procedimentos Médicos Invasivos Baseado em Realidade Virtual para Treinamento de Transplante de Medula Óssea. In: $5^{\text {th }}$ Symposium on Virtual Reality, 2002. Proceedings. Fortaleza/CE: SBC, outubro de 2002. p.416-418.

[MACHADO e ZUFFO, 2003] Machado, L.S. Zuffo, M.K. Development and Evaluation of a Simulator of Invasive Procedures in Pediatric Bone Marrow Transplant. Medicine Meets Virtual Reality 2003. Studies in Health Technology and Informatics, Amsterdam: IOS Press, 2003. [no prelo]

[MAHONEY, 1994] Mahoney, D.P. Virtual Science. Computer Graphics World, p. 20-26, julho de 1994.

[MAHONEY, 1995] Mahoney, D.P. Driving VR. Computer Graphics World, p.22-33, maio de 1995.

[MAHONEY, 1997] Mahoney, D.P. The Power of Touch. Computer Graphics World, v.20, n. 8, p. 41-48, agosto de 1997.

[MAHONEY, 1998] Mahoney, D. The Eyes Have It. Computer Graphics World, p. 69-70, agosto de 1998.

[MAKSOUD, 1998] Maksoud, J.G. Cirurgia Pediátrica. Volume II. Rio de J aneiro, Editora Revinte, 1998.

[MASSIE, 1998] Massie, T. Physical Interaction: The Nuts and Bolts of Using Touch Interfaces. $25^{\text {th }}$ International Conference on Computer Graphics and Interactive Techniques. Course Notes, n.1, 1998.

[MASSIE e SALISBURY, 1994] Massie, T.; Salisbury, J.K. The PHANTOM Haptic Interface: A Device for Probing Virtual Objects. ASME Winter Annual Meeting Proceedings. IL, novembro de 1994. Disponível online em: http://www.sensable.com.

[MAYR, 2001] Mayr, H. Virtual Eye Muscle Surgery Based Upon Biomechanical Models. Medicine Meets Virtual Reality. Studies in Health Technology and Informatics, n. 81, p. 305-311. IOS Press, 2001.

[MCCARTHY et al., 1999] McCarthy, A.; Harley, P.; Smallwood, R. Virtual Arthroscopy Training: Do the "Virtual Skills" Developed Match the Real Skills Required? Medicine Meets Virtual Reality. Studies in Health Technology and Informatics, vol. 62, pp.221-227. Amsterdam, IOSPress, 1999.

[MCINERNEY e TERZOPOULOS, 1996] Mcinerney, T.; Terzopoulos, D. Deformable Models in Medical Image Analysis: A Survey. Medical Image Analysis, v.1, n.2, 1996.

[MELLO, 2001] Mello, A. N. Oncologia Pediátrica e Transplante de Medula Óssea. Comunicação pessoal com o Dr. André Nebel de Mello, 
especialista em oncologia pediátrica. Departamento de Pediatria,

Faculdade de Medicina da Universidade de São Paulo, São Paulo, 2001.

[MERL, 1999] Surgical Simulation and Training. Mitsubishi Online:

http://www.merl.com/projects/surgical. Acesso em novembro de 1999.

[MIAS, 1998] Minimally Invasive Articular Surgery. Online: http://ligwww.epfl.ch/ thalmann/mias.html. Acesso em dezembro de 1998.

[NETTO et al, 2002] Netto, A.V.; Machado, L.S.; Oliveira, M.C.F. Realidade Virtual. Florianópolis, Visual Books, 2002.

[ODONE $\mathrm{F}^{\circ}, 2001$ ] Odone $\mathrm{F}^{\circ}, \mathrm{V}$. Oncologia e Transplante de Medula Óssea. Comunicação pessoal com o Dr. Vicente Odone Filho, especialista em oncologia pediátrica. Departamento de Pediatria, Faculdade de Medicina da Universidade de São Paulo, São Paulo, 2001.

[OPPENHEI MER et al., 2000] Oppenheimer, P.; Weghorst, S.; Williams, L.; Ali, A.; Cain, J.; MacFarlane, M.; Sinanan, M. Laparoscopic Surgical Simulator and Port Placement Study. Medicine Meets Virtual Reality. Studies in Health Technology and Informatics, n. 70, p. 233- 235. IOS Press, 2000.

[OTTENSMEYER et al., 2000] Ottensmeyer, M.P.; Ben-Ur, E.; Salisbury, J.K. Input and Output for Surgical Simulation: Devices to Measure Tissue Properties in vivo and Haptic Interface for Laparoscopy Simulators. Medicine Meets Virtual Reality. Studies in Health Technology and Informatics n.70, p. 236-242. IOS Press, 2000.

[OTTENSMEYER, 2002] Ottensmeyer, M.P. In vivo Measurement of Solid Organ Visco-elastic Properties. Medicine Meets Virtual Reality. Studies in Health Technology and Informatics n.85, p. 514-519. IOS Press, 2002.

[PEIFER, 1999] Peifer, J. Eye Surgery Simulation. Online: http://www.bitc.gatech.edu/bitcprojects/eye_sim/eye_surg_sim.html. Acesso em outubro de 1999.

[PIMENTEL e TEIXEIRA, 1995] Pimentel, K.; Teixeira, K. Virtual Reality Through the New Looking Glass. $2^{\text {nd }}$ ed, New York, McGraw Hill, 1995.

[PIZZO e POPLACK, 1997] Pizzo, P.A.; Poplack, D.G. Principles and Practice of Pediatric Oncology. Filadelfia, Lippincott-Raven Publishers, 1997.

[RHEIGOLD, 1991] Rheingold, Howard. Virtual Reality. New York, Touchstone, 1991.

[ROSEMBLUM et al., 1998] Rosemblum, L.; Burdea, G.; Tachi, S. VR Reborn. IEEE Computer Graphics and Applications, v.18, n.6, p.21-23, 1998. 
[ROSEN et al., 1996] Rosen, J. et al. Virtual Reality and Medicine: From Training Systemas to Performance Machines. Proceedings of VRAIS'96, p. 5-13, IEEE, 1996.

[ROSEN et al., 2001] Rosen, J.; Solazzo, M.; Hannaford, B.; Sinanan, M. Objective Laparoscopic Skills Assessments of Surgical Residents Using Hidden Markov Models Based on Haptic Information and Tool/Tissue Interactions. Medicine Meets Virtual Reality. Studies in Health Technology and Informatics n.81, p. 417-423. IOS Press, 2001.

[SAGAR et al., 1994] Sagar, M.; Bullivant, D.; Mallinson, G. Hunter, P. A Virtual Environment and Model of the Eye for Surgical Simulation. Computer Graphics, SIGGRAPH'94 Proceedings, p. 205-212, julho de 1994.

[SALISBURY, 1995] Salisbury, K. Haptics: The Technology of Touch. HPCWire Special, novembro de 1995. Disponível também online em: http://www.sensable.com/community/haptwhpp.htm.

[SATAVA, 2000] Satava, R. Medicine 2001: The King is Dead. Virtual Reality Conference 1994. Disponível em: http://www.csun.edu/cod/conf/1994/proceedings/Med 1.html. Acesso em setembro de 2002.

[SCHILL et al., 1999] Schill, M.; Wagner, C.; Hennen, M.; Bender, H.; Männer, R. EyeSi A Simulator for Intra-Ocular Surgery. Lecture Notes in Computer Science, v. 1679. Medical Image Computing and ComputerAssisted Intervention Conference (MICCAI'99). Springer, 1999.

[SCHUTYSER et al., 1999] Schutyser, F.; Cleynenbreugel, J.; Schoenaers, J .; Marchal, G.; Suetens, P. A Simulation Environment for Maxillofacial Surgery Including Soft Tissue Implications. MICCAI' 99 Proceedings. Lecture Notes in Computer Science, n. 1679, p. 1210-1217. Springer, 1999.

[SENSABLE, 2002] Sensable. Online: http://www.sensable.com. Último acesso em novembro de 2002.

[SHERMAN et al., 1999] Sherman, K.; Ward, J.; Wills, D.; Mohsen, A. A Portable Virtual Environment Knee Arthroscopy Training System with Objective Scoring. Medicine Meets Virtual Reality. Studies in Health Technology and Informatics n.62, p. 335-336. IOS Press, 1999.

[SHERMAN et al., 2001] Sherman, K.; Ward, J.; Wills, D.; Sherman, V.; Mohsen, A. Surgical Trainee Assessment using a VE Knee Arthroscopy Training System (VE-KATS): Experimental Results. Medicine Meets Virtual Reality. Studies in Health Technology and Informatics n. 81, p. 465-470. IOS Press, 2001.

[SMITH et al., 1999] Smith, S.; Wan, A.; Taffinder, N.; Read, S.; Emery, R.; Darzi, A. Early Experience and Validation Work With Procedicus VA - The Prosolvia Virtual Reality Shoulder Arthroscopy Trainer. Medicine Meets 
Virtual Reality. Studies in Health Technology and Informatics n.62, p. 337-343. IOS Press, 1999.

[SOFTIMAGE, 2003] Softlmage Products. Online:

http://www.softimage.com/products/. Acesso em fevereiro de 2003.

[SORID e MOORE, 2000] Sorid, D.; Moore, S.K. The Virtual Surgeon. IEEE Spectrum, v.37, n.7, p.26-31, julho de 2000.

[SOURIN et al., 2000] Sourin, A.; Sourina, O.; Tet Sen, H. Virtual Orthopedic Surgery Training. IEEE Computer Graphics and Applications, v. 20, n. 3, maio/junho de 2000.

[SRINIVASAN e BASDOGAN, 1997] Srinivasan, M.A.; Basdogan, C. Haptics in Virtual Environments: Taxonomy, Research Status, and Challenges. Computer \& Graphics, v.21, n.4, p.393-404. Elsevier Science, 1997.

[SRI NIVASAN et al., 1999] Srinivasan, M.A.; Basdoga, C. Ho, C-H. Haptic Interactions in the Real and Virtual Worlds. Specification and Verification of Interactive Systems'99. Eds. Duke and Puerta, Springer-Verlag Wien, 1999.

[STEREOGRAPHICS, 1997a] CrystalEyes ${ }^{\text {TM }}$ Software Development Kit. Stereographics Corporation. Dezembro, 1997. Disponível online em: http://www.stereographics.com.

[STEREOGRAPHICS, 1997b] Stereographics Developers' Handbook. Stereographics Corporation. 1997. Disponível online em: http://www.stereographics.com.

[STEWART, 1992] Stewart, S.K. Bone Marrow Transplants - A Books of Basics for Patients. Blood \& Marrow Transplant Newsletter, Illinois, 1992.

[SUTHERLAND, 1965] Sutherland, I van. The Ultimate Display. In: IFIP Congress, 1965. Proceedings. 1965, p. 506-508.

[SZÉKELY e SATAVA, 1999] Székely, Gábor; Satava, Richard. Virtual Reality in Medicine. BMJ (www.bmj.com), v. 319, p. 1-4, 13 de novembro de 1999.

[SZÉKELY et al., 1999] Székely, G. et al. Virtual Reality Based Surgery Simulation for Endoscopic Gynaecology. Medicine Meets Virtual Reality. Studies in Health Technology and Informatics n.62, p. 351-357. IOS Press, 1999.

[TAY et al. 2002] Tay, B.K.; Stylopoulos, N.; Rattner, D.W.; Srinivasan, M.A. Measurement of In-vivo Force Response of Intra-abdominal Soft Tissues for Surgical Simulation. Medicine Meets Virtual Reality. Studies in Health Technology and Informatics n.85, p. 514-519. IOS Press, 2002.

[TROWBRIDGE e HOLLANDS, 1999] Trowbridge, T.; Hollands, R. Virtual Arthroscopy Knee Surgery Simulator. Virtual Reality in Medicine and 
Biology Group. Online: http://www.shef.ac.uk/ vrmbg/arthro1.html. Acesso em outubro de 1999.

[TSAl et al., 2001] Tsai, M.; Hsieh, M.; J ou, S. Virtual Reality Orthopedic Surgery Simulator. Computer in Biology and Medicine, n. 31, p. 333-351, 2001.

[TSUKUBA, 2002] I wata Lab./Tsukuba - HapticMaster. Online: http://intron.kz.tsukuba.ac.jp/vrlab_web/hapticmaster/hapticmaster_e.ht ml. Acesso em abril de 2002.

[VENCIGUERRA, 2000] Venciguerra, M. USP Usa Telemedicina para Tratar Criança com Câncer na Rede Pública. J ornal Gazeta Mercantil, n. 487, p.1, Caderno Grande São Paulo, São Paulo, 13 de março de 2000.

[VINCE, 1995] Vince, J ohn. Virtual Reality Systems. New York, AddisonWesley, 1995.

[VOSS et al., 2000] Voss, G.; Brockholt, U.; Los Arcos, J.; Müller, W.; Oppelt, P.; Stäler, J. Lahystotrain - Intelligent Training System for Laparoscopy and Hysteroscopy. Medicine Meets Virtual Reality. Studies in Health Technology and Informatics, n. 70, p. 359-364. IOS Press, 2000.

[WEBSTER et al., 2001] Webster, R.; Zimmerman, D.; Mohler, B.; Melkonian, M.; Haluck, R. A Prototype Haptic Suturing Simulator. Medicine Meets Virtual Reality. Studies in Health Technology and Informatics, n. 81, p. 567-569. IOS Press, 2001.

[WESTWOOD et al., 1999] Westwood, J.D.; Hoffman, H.M.; Robb, R.A.; Stredney, D. eds. The Convergence of Physical and Informational Technologies: Options for a New Era in Health Care. Medicine Meets Virtual Reality. Studies in Health Technology and Informatics, v. 62. IOSPress, 1999.

[WESTWOOD et al., 2000] Westwood, J.D.; Hoffman, H.M.; Mogel G.T.; Robb, R.A.; Stredney, D. eds. Envisioning Healing: Interactive Technology and the Patiente-Practioner Dialogue. Medicine Meets Virtual Reality. Studies in Health Technology and Informatics, v. 70. IOSPress, 2000.

[WESTWOOD et al., 2001] Westwood, J.D.; Hoffman, H.M.; Mogel G.T.; Stredney, D. eds. Outer Space, Inner Space, Virtual Space. Medicine Meets Virtual Reality. Studies in Health Technology and Informatics, v. 85. IOSPress, 2001.

[WESTWOOD et al., 2002] Westwood, J.D.; Hoffman, H.M.; Mogel G.T.; Stredney, D. eds. Digital Upgrades: Applying the Moore's Law to Health. Medicine Meets Virtual Reality. Studies in Health Technology and Informatics, v.85. IOSPress, 2002.

[YAGEL et al., 1996] Yagel, R.; Stredney, D.; Wiet, G.; Schmalbrock, P.; Rosenberg, L.; Sessanna, D.; Kurzion, Y. Building a Virtual Environment 
for Endoscopic Sinus Surgery Simulation. Computers \& Graphics, v. 20, n. 6, p. 813-823, 1996.

[ZIEGLER et al., 1995] Ziegler, R.; Fischer, G.; Müller, W.; Göbel, M. Virtual Reality Arthroscopy Training Simulator. Computer in Biology and Medicine, v.25, n.2, p. 193-203, 1995.

[ZILLES, 1995] Zilles, C.B. Haptic Rendering with the Toolhandle Haptic Interface. 1995. 46p. Dissertação de Mestrado - Massachusetts Institute of Technology.

\subsection{Bibliografia Complementar}

Desenvolvimento de Sistemas de RV

Gradecki, J. Kit de Montagem da Realidade Virtual. Editora Berkeley, Rio de J aneiro, 1994.

Ware, C.; Arthur, K.; Booth, K. Fish Tank Virtual Reality. Proceedings of the Conference on Human Factors in Computing Systems 1993, p. 37-42. ACM, 1993.

\section{Medicina e Coleta de Medula Óssea}

Fishbein, M. Enciclopédia Familiar da Medicina e Saúde. Volume 1. 7a edição. Enciclopédia Barsa, 1967.

Tortora, G.J . Corpo Humano. Fundamentos de Anatomia e Fisiologia. $4^{a}$ edição. Porto Alegre, Artmed, 2000.

\section{Sistemas Hápticos}

Hirota, K.; Hirose, M. Providing Force Feedback in Virtual Environments. IEEE Computer Graphics \& Applications, v. 15, n. 5, p. 22-30. IEEE, setembro de 1995.

Lee, C.; Lawrence, D.; Pao, L. A High-Bandwidth Force-Controlled Haptic Interface. Symposium on Haptic Interfaces for Teleoperation and Virtual Reality. ASME, novembro de 2000.

MPB Technologies Inc. Freedom 6S. Online: http://www.mpbtechnologies.ca. Acesso em abril de 2002.

Ramstein, C.; Hayward, V. The PANTOGRAPH: a Large Workspace Haptic Device for a Multi-Modal Human-Computer Interaction. Conference on Human Factors in Computing Systems Proceedings. ACM, abril de 1994.

Tan, H. Z. Haptic Interfaces. Communications of the ACM, v.43, n.3, p. 4041, 2000. 


\section{Anexo 1 - Tabela de Valores de Calibragem}

\begin{tabular}{|l|c|c|c|c|}
\cline { 2 - 5 } \multicolumn{1}{c|}{} & \multicolumn{4}{c|}{ Camadas } \\
\cline { 2 - 5 } \multicolumn{1}{c|}{} & Pele & Osso & Medula & Calotas \\
\hline Atrito Estático $^{1}$ & 0,6 & 0,6 & 0,9 & 0,6 \\
\hline Atrito Dinâmico $^{2}$ & 0,6 & 0,1 & 0,9 & 0,1 \\
\hline Rigidez $^{3}$ & 2 & 4 & 2,5 & - \\
\hline Elasticidade $^{4}$ & 0,25 & 0,8 & 0,9 & 0,4 \\
\hline Coeficiente de Viscosidade (k) $^{n}$ & 0,006 & 0,0065 & 0,004 & - \\
\hline
\end{tabular}

Tabela 3: Valores utilizados na calibragem das camadas de tecido do Simulador de Coleta de Medula Óssea.

${ }^{1}$ Valor adimensional no intervalo $(0 . .1,0)$ para a chamada setSurfaceFstatic(float $n$ ).

${ }^{2}$ Valor adimensional no intervalo $(0 . .1,0)$ para a chamada setSurfaceFdynamic(float $n$ ).

${ }^{3}$ Valor no intervalo $(0 . .6,4)$ Newtons considerando-se o valor de pico do vetor normal de força do Phantom.

${ }^{4}$ Valor adimensional no intervalo (0.. 1,0) para a chamada setSurfaceKdamping(float $n$ ). 


\section{Anexo 2 - Diagramas de Classe}

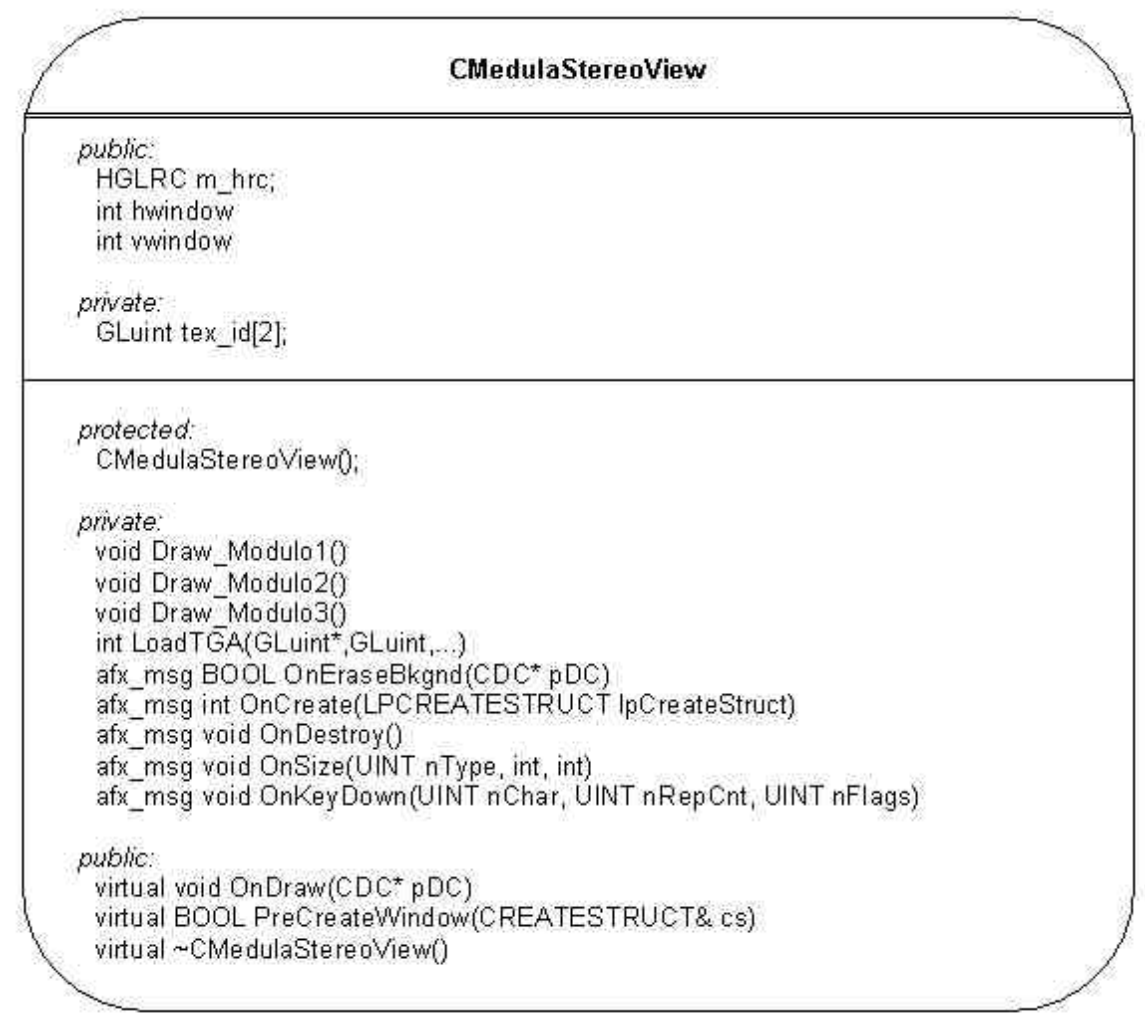

Figura 35: Diagrama da classe CMedulaStereoView.

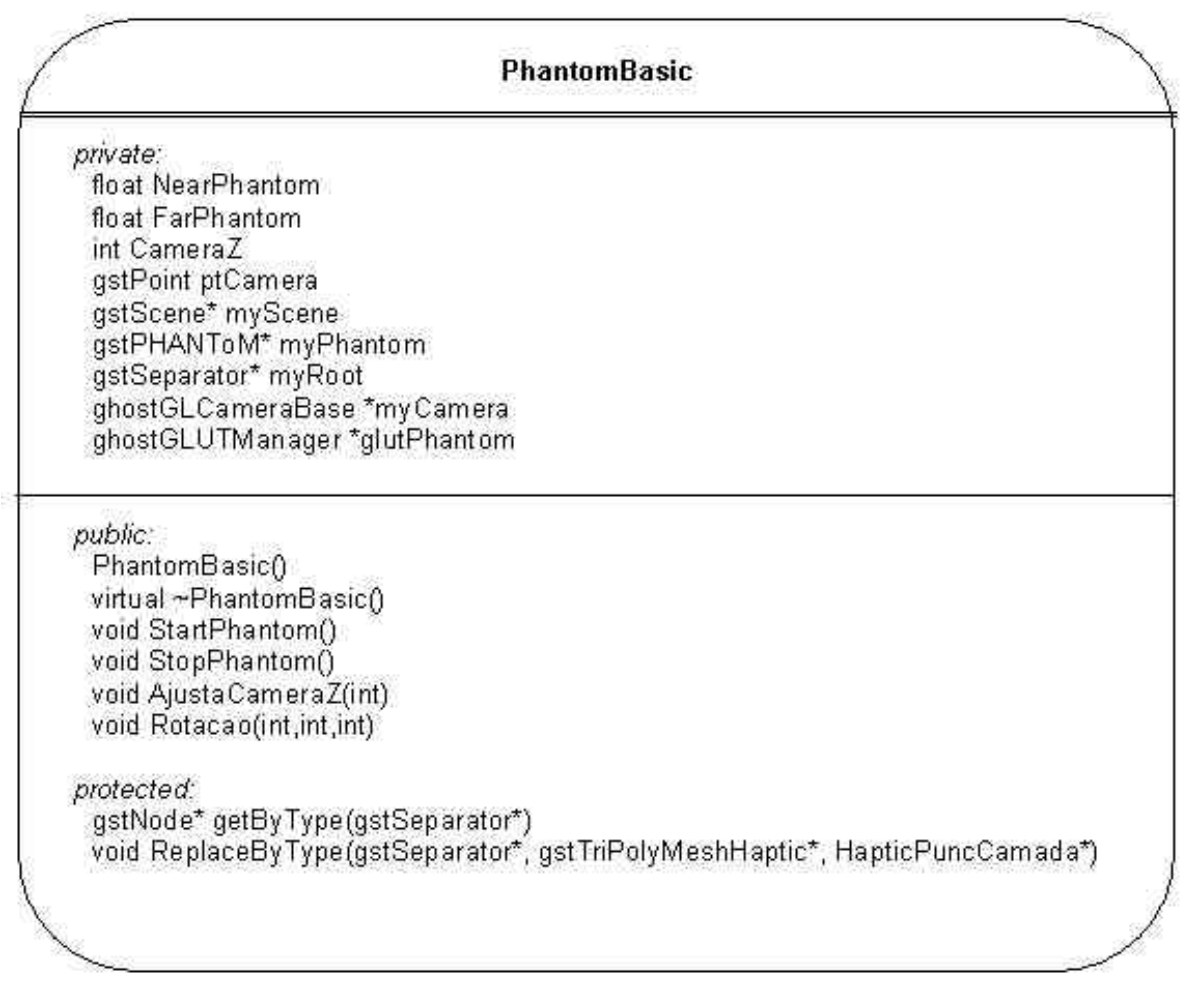

Figura 36: Diagrama da classe PhantomBasic. 


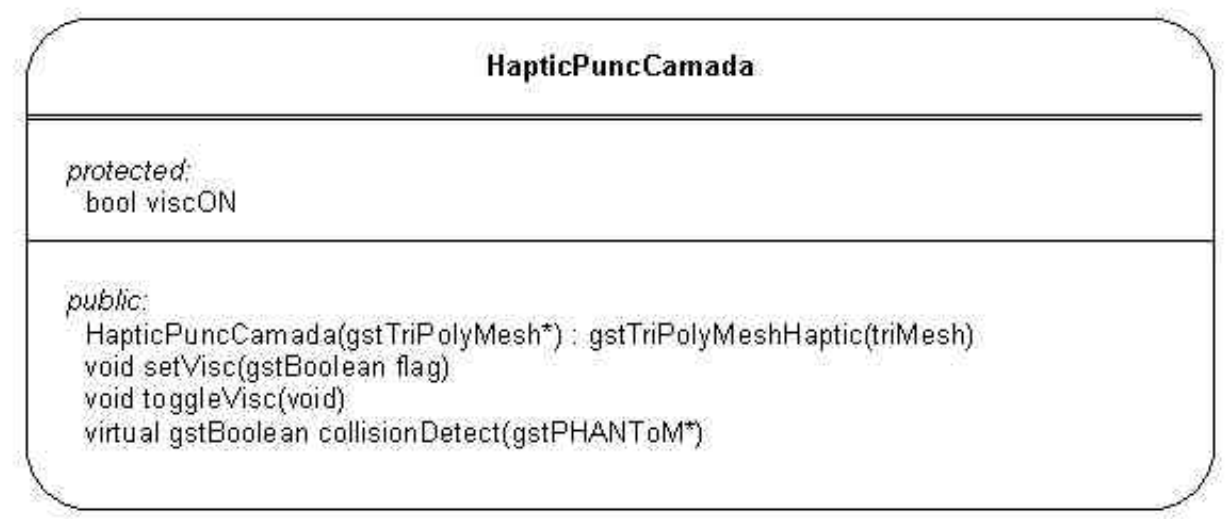

Figura 37: Diagrama da classe HapticPuncCamada.

\begin{tabular}{|c|}
\hline ViscEffect \\
\hline $\begin{array}{l}\text { protected: } \\
\text { double eta }\end{array}$ \\
\hline $\begin{array}{l}\text { public: } \\
\text { ViscEffect0:gstEffect) } \\
\sim \text { ViscEffect0 } \\
\text { virtual gst Vector calcEffectForce (void *data); } \\
\text { virtual gstVector calcEffectForce (void *data, gst Vector \&torques) } \\
\text { void setEta(double val) } \\
\text { double getEta(void) }\end{array}$ \\
\hline
\end{tabular}

Figura 38: Diagrama da classe ViscEffect.

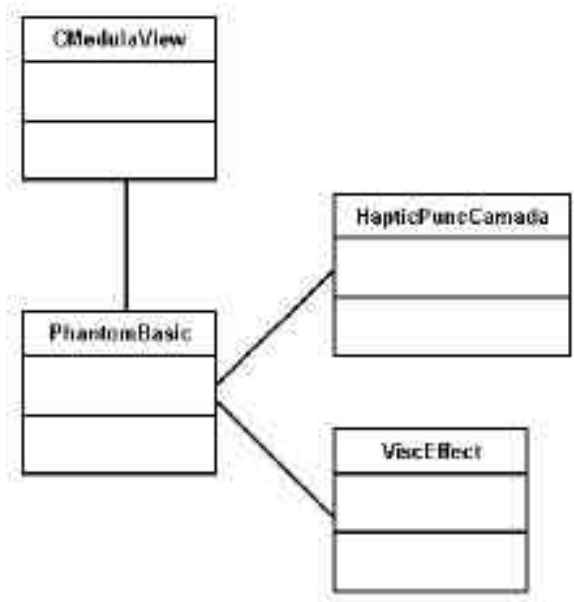

Figura 39: Diagrama das classes de visualização e atuação háptica. 


\section{Glossário}

API - Application Programming Interface ou Interface de Programação de Aplicativos. É um conjunto de rotinas e funções pré-compiladas e prontas (normalmente na forma de dll's) que realizam uma tarefa comum. Estas interfaces foram concebidas para padronizar recursos do sistema operacional utilizados pelos aplicativos.

graus de liberdade - número de possibilidades de flexibilidade e/ou movimentação. Em sistemas de realidade virtual 6DOF o usuário pode movimentar-se no ambiente 3D através das três direções $X, Y, Z$ e das três rotações ao redor destes eixos.

háptico - adjetivo utilizado para designar equipamentos capazes de permitir a seres humanos interação tátil em ambientes reais ou virtuais.

HMD - head-mounted display; nome dado aos dispositivos de visualização usados na cabeça que apresentam as imagens em pequenas telas posicionadas diante dos olhos do usuário. Geralmente, abrigam também a parte de som e detecção de movimento.

Phantom - Personal Haptic Interface Mechanism: dispositivo para interação háptica baseado em um braço mecânico comercializado pela Sensable Technologies (http://www.sensable.com).

projeção perspectiva - projeção de imagens tridimensionais no plano que leva em conta aspectos de posicionamento do observador em relação ao objeto; dessa forma, objetos mais distantes do observador são menores proporcionalmente que objetos mais próximos.

rendering - processo de criação de imagens e/ou modelos através de técnicas de computação gráfica. 
VRML - Virtual Reality Modeling Language ou Linguagem de Modelagem de Realidade Virtual. Linguagem de descrição de cena/linguagem de programação que permite a criação de ambientes de três dimensões desenvolvida por Mark Pesce e Tony Parisi em 1994. Estes ambientes (chamados de mundos) podem ser mostrados em um navegador. 